
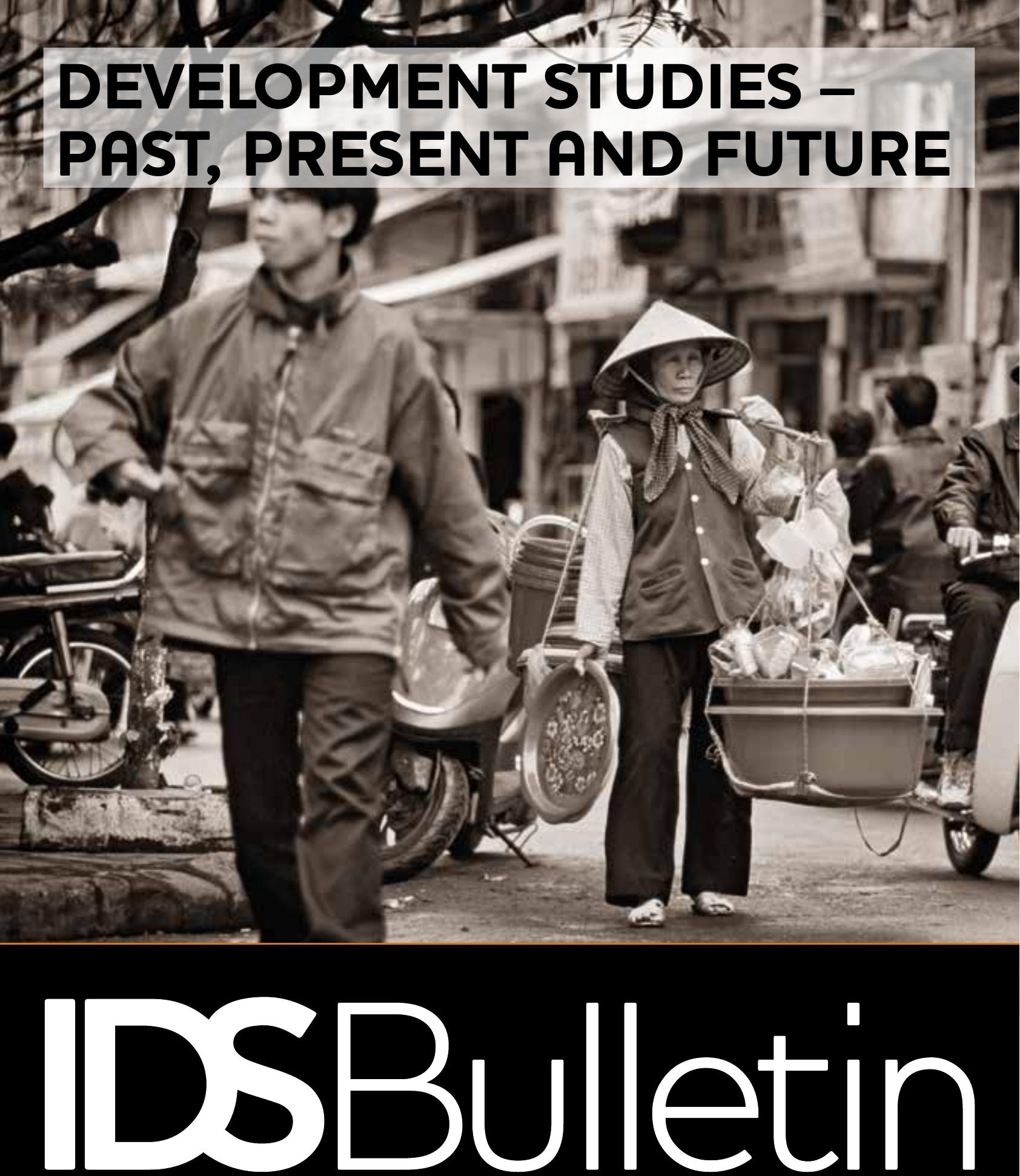

Transforming Development Knowledge 
IDS Bulletin The IDS Bulletin is an open access, peer-review journal exploring emerging international development challenges. It is published bi-monthly and is the flagship publication of the Institute of Development Studies, a leading global institution for research, teaching and learning, and impact and communications, based the University of Sussex. Progressive economic, social and political change for everyone needs new kinds of action and relationships, shaped by new kinds of research and engagement. The IDS Bulletin aims to transform development knowledge, through its unique thematic issues developed by global learning partnerships that bridge academic, practice and policy discourse.

Publishing Manager/Bulletin Editorial Coordinator Alison Norwood Marketing and Production Officer Gary Edwards

Publisher The IDS Bulletin is published by the Institute of Development Studies, Library Road, Brighton BN1 9RE, UK. Tel: +44 (0)1273 606261 .

Cover photo Hanoi, Vietnam. Street scene in Hang Bac.

Photographer (C) Macduff Everton/Corbis

Disclaimer The Publisher and Issue Editors cannot be held responsible for errors or any consequences arising from the use of information contained in this journal; the views and opinions expressed do not necessarily reflect those of the Publisher and Issue Editors, neither does the publication of advertisements constitute any endorsement by the Publisher and Issue Editors of the products advertised.

Copyright and photocopying IDS Bulletin (c) Institute of Development Studies

This issue is published under CC BY-NC licence (see individual articles for relevant re-use conditions).

(c) BY-NC Authorisation to photocopy or distribute items for internal and personal use is granted by the copyright holder for libraries and other users registered with their local Reproduction Rights Organisation (RRO) e.g. Copyright Licensing Agency Ltd, 90 Tottenham Court Road, London W1P 9HE, UK, www.cla. co.uk. This consent does not apply for any forms of commercial re-use of material and requests to reproduce for resale must be made to Gary Edwards, Marketing and Production Officer, IDS Communications and Engagement Unit, idsbulletin@ids.ac.uk.

Information for subscribers The IDS Bulletin is published in six issues per year. Institutional subscription price for 2016 is £395 (no VAT applicable).

Delivery terms and legal title Prices include delivery of print journals to the recipient's address. Delivery terms are Delivery Duty Unpaid (DDU); the recipient is responsible for paying any import duty or taxes. Legal title passes to the customer on despatch.

Advertising enquiries Gary Edwards, Marketing and Production Officer, IDS Communications and Engagement Unit, idsbulletin@ids.ac.uk

IDS Bulletin (C) Institute of Development Studies 2016 www.ids.ac.uk IDS is a charitable company limited by guarantee and registered in England (No. 877338). 


\section{Notes on contributors}

Naysan Adlparvar recently completed his PhD at IDS investigating ethnic and sectarian identity in relation to conflict and reconstruction efforts in Afghanistan. He has also published research investigating the gendered impacts of microfinance programming. Before commencing his $\mathrm{PhD}$, he worked in Afghanistan with local and international non governmental organisations (NGOs), the United Nations Development Programme (UNDP) and the Government of Afghanistan. His current research interests include the changing nature of identity and intergroup relations in Afghanistan, and communitydriven peace-building and its contribution to social cohesion. He presently works with UNDP in Iraq on community-focused poverty reduction and private sector development initiatives.

Alia Aghajanian is a $\mathrm{PhD}$ student at IDS. Her thesis considers the consequences of returning home after conflict-induced displacement, specifically looking at social capital, labour market outcomes and household welfare. While at IDS, Alia was also an early stage Research Fellow with the Marie Curie Training and Mobility Network for the Economic Analysis of Conflict (TAMNEAC), funded by the European Commission. This research included primary data collection using household surveys in Maharashtra, India, Lebanon and Ghana (where she worked with the Ghana Statistical Office). Alia has also just joined Oxford Policy Management as a consultant with the Official Statistics Portfolio.

Jeremy Allouche is a Research Fellow at IDS, co-leading the Resource Politics Cluster, and the IDS PhD convenor. He is a member of the Sussex Centre for Conflict and Security Research. He previously worked at the University of Oxford, the Massachusetts Institute of Technology (MIT), the Swiss Graduate Institute of Public Administration and the Graduate Institute of International and Development Studies, Geneva. His fields of interest are the intersection between global environmental change, security and development. He is currently leading two major projects: Large Development Investment and Local Peacebuilding in Rural Africa, and a STEPS Centre project on the water-energy-food nexus.

Stephen Devereux has been a researcher at IDS since 1996. He worked initially on food security in Africa and the analysis of famines. Since the early 2000s his work has focused increasingly on social protection - conceptual frameworks, policy formulation, design choices, programme evaluations, teaching and training. He was a founding director of the Centre for Social Protection (2005). He co-edited the IDS Bulletin's 40th Anniversary special issue: 'Challenging Orthodoxies, Influencing Debates' (37.4, 2006, http://bulletin.ids.ac.uk/idsbo/issue/ view/66). He holds a UK-South Africa Bilateral Research Chair in 
'Social Protection for Food Security', the Centre of Excellence in Food Security, University of the Western Cape.

Jenny Edwards is Programme Officer for the Pathways of Women's Empowerment programme at IDS. She studied Cultures and Communities at the University of Sussex and her dissertation was on the politics of step mothering as portrayed in children's literature. With Andrea Cornwall, she co-edited Feminisms, Empowerment and Development: Changing Women's Lives (Zed Books, 2014) and two issues of the IDS Bulletin: 'Beijing+20: Where now for Gender Equality?' (46.4, 2015, http://bulletin.ids.ac.uk/idsbo/issue/view/15) and 'Negotiating Empowerment' (41.2, 2010, http://bulletin.ids.ac.uk/idsbo/issue/view/44).

Hadeer Elshafie is a $\mathrm{PhD}$ researcher at IDS who is studying the dynamics of citizen environmental action in both urban and online spaces. Hadeer's earlier research looked at the dynamics governing common-pool resource management in developing countries, with a focus on inland fisheries. Prior to joining IDS, Hadeer attained her BA in political economy and MA in professional development from the American University in Cairo.

John Gaventa is Director of Research at IDS, and has been a Research Fellow since 1996. He is currently linked to the Power and Popular Politics cluster and previously served as Director of the Development Research Centre on Citizenship, Participation and Accountability, based at IDS (2000-11), and of the former Participation team. He has worked as staff member and director of the Highlander Center in the United States (1976-94), as Director of the Coady International Institute at STFX University, Canada (2011-14) and as Chair of Oxfam Great Britain (2006-11). He has written widely on issues of power and participation.

Rachel Godfrey-Wood has degrees from the London School of Economics (BA History) and the Institute for the Study of the Americas (MSc in Globalisation and Latin American Development). She is currently completing a $\mathrm{PhD}$ on the impacts of social protection on older persons' wellbeing in rural Bolivia, and she is also interested in the interplay between climate change adaptation and social protection. Rachel also works on a number of other issues as a consultant for the International Institute for Environment and Development (IIED).

Martin Greeley is a Fellow at IDS, working on poverty and public policy. He is a development economist with nearly 40 years' experience including ten years of long-term overseas research (India, Sri Lanka and Bangladesh). He specialises in rural issues and has led several major research projects on agricultural technology choices and their output and employment consequences. Martin has taught graduate programmes at the University of Sussex on agriculture and development theory and has led Study Seminars in sub-Saharan Africa on structural adjustment. He has worked with the World Bank, several UN agencies and many bilateral donors. 
Jaideep Gupte is a Research Fellow and co-leader of the Cities cluster, IDS, where his research is on urban violence, poverty and development. He was formerly a Research Fellow at the Urban Design Research Institute, Mumbai. Other research interests and expertise include micro level politics and economics of slum resettlement, informal justice/ security in informal settlements, and using GIS/GPS-aided mobile data collection platforms for spatial research. Jaideep's training is in politics (DPhil, University of Oxford), development studies (MPhil, University of Sussex) and economics (BA Hons, Simon Fraser University).

Richard Jolly is Honorary Professor and Research Associate of IDS, where he was director in the 1970s. He has been a Trustee of OXFAM, a Council member of the Overseas Development Institute (ODI) and Chairman of the UN Association of the United Kingdom and President of the British Association of Former UN Civil Servants. From 1982 to 1996, Richard Jolly was an Assistant Secretary General of the United Nations, serving as deputy executive director responsible for UNICEF's programmes worldwide. He was then until 2000 senior adviser to the Administrator of the United Nations Development Programme (UNDP) and coordinator of the widely-acclaimed Human Development Report. After leaving the UN he was co-director of the UN Intellectual History Project overseeing a multi-volume history of the UN's contributions to economic and social ideas and policy. He was a co-author of several of the volumes and senior author of the final volume, UN Ideas That Changed the World. In 2014 he published a book on UNICEF: Global Governance that Works. He was knighted by the Queen in 2001 for his services to international development.

Tamahi Kato has been working as a researcher and practitioner in human development, peace-building and poverty reduction. She has worked with the United Nations Development Programme (UNDP) Human Development Report Office, the UN Mission in Guatemala and the Overseas Development Institute (ODI)/Chronic Poverty Research Centre, where she did a country study review on chronic poverty in Tanzania. Tamahi's PhD research analyses the impact of agricultural input subsidy programmes in sub-Saharan Africa, focusing on a case study of Ruvuma Region, Tanzania. Tamahi analysed the impacts on maize yields and poverty, and looked specifically at the aim, design and implementation of the programme as a cause of the impacts.

Hani Morsi is a post-doctoral researcher at the Access to Knowledge for Development Center, American University in Cairo, where he is working on a critical investigation of conceptual notions of openness. Hani is specifically interested in the factors that enable individuals and communities to capitalise on increasingly open learning and knowledge co-construction opportunities. Previously, Hani was a PhD candidate working within the Power and Popular Politics and Digital Development clusters, IDS where his thesis looked at the implications of emerging information and communications technologies on collective action and political activism in restrictive environments, with extensive fieldwork conducted in Egypt. 
Lars Otto Naess is a Research Fellow at IDS. He is a social scientist and has worked on climate change, development and agriculture over the past 20 years. His current research interests are the political and institutional dimensions of climate change and development, the role of local knowledge for adaptation to climate change, and adaptation planning in the context of international development cooperation. Previous affiliations include the Center for International Climate and Environmental Research-Oslo (CICERO), the Tyndall Centre for Climate Change Research at the University of East Anglia, and the UN Food and Agriculture Organization (FAO).

Zahrah Nesbitt-Ahmed is a Research Fellow in the Cities cluster, IDS. She is a human geographer by training with extensive experience in gender and urbanisation, with a particular focus on West African cities. She currently works on issues related to women's economic empowerment and women's rights.

Alison Norwood is Publishing Manager at IDS, and Editorial Coordinator of the IDS Bulletin. She focuses on academic publications, working on both editorial production and advising on wider publishing matters through writing and disseminating in-house guidelines. A key part of Alison's work is the evolving landscape into digital publishing and the increasing adoption of Open Access. Her current interests are maintaining the quality and scale of the existing IDS publishing programme while researching implications for the institutional Open Access policy on outputs. Alison works closely with the IDS Bulletin's Editorial Steering Group, and has considerable publishing experience with commercial publishers prior to joining IDS.

Maro Pantazidou works on the intersections of human rights, politics and learning. She is the Lead Adviser for Organisational Learning and Accountability with Amnesty International. Previously, she has worked with both grass-roots and international organisations to introduce reflective practice and power analysis into their strategy and practice. She is interested in emerging forms of citizen organisation and action and the implications for civil society and human rights work, and has taken part as a researcher or facilitator in a number of related research projects including with IDS, Hivos and the London School of Economics and Political Science (LSE).

Ricardo Santos is a Research Fellow at the United Nations University World Institute for Development Economics Research (UNU-WIDER) and visiting researcher at the National Centre of Scientific Research (CNIC), National University of Timor-Leste (UNTL) in Timor-Leste. He holds a PhD in economics from IDS, a master's in economics from Nova University, Lisbon and an MA in development studies from IDS. He also has practitioner experience in international development, as Country Manager (Timor-Leste and Angola) and Deputy Executive Officer at a Portuguese volunteering INGO, Leigos para o Desenvolvimento. 
Ana Solórzano holds a PhD from IDS, where she researched the linkages between social protection and climate change resilience using as a case study the Oportunidades programme, Mexico. She has conducted extensive research and has engaged in work on poverty and vulnerability, social protection, climate shocks, climate change adaptation and resilience for more than eight years, including practical and research work in governmental agencies in Mexico (Ministry of Social Development and the National Population Council), as well as consultancy work with the Department for International Development (DFID), the UN and the Inter-American Development Bank. Ana is a consultant at Oxford Policy Management.

Mariz Tadros is the co-leader of the Power and Popular Politics cluster, IDS. Her most recent monograph is Resistance, Revolt and Gender Justice in Egypt (Syracuse University Press, 2016). She is the editor of Women in Politics, Gender Power and Development (Zed Books, 2014), author of The Muslim Brotherhood in Contemporary Egypt: Democracy Redefined or Confined? (Routledge Press, 2012), author of Copts at the Crossroads (American University in Cairo Press, 2012) and editor of three issues of the IDS Bulletin: 'The Pulse of Egypt's Revolt' (43.1, 2012, http://bulletin.ids.ac.uk/idsbo/issue/view/33); 'Religion, Rights and Gender at the Crossroads' (42.1, 2011, http://bulletin.ids.ac.uk/idsbo/ issue/view/39); and 'Quotas: Add Women and Stir?' with A.A. Alcântara Costa (41.5, 2010, http://bulletin.ids.ac.uk/idsbo/issue/view/41). 
This page is intentionally left blank 


\section{Foreword}

This is a special year for IDS and for the IDS Bulletin, and I am delighted to introduce this issue which brings together many of the special features that we are celebrating this year.

2016 is the Institute's 50th Anniversary: a year in which we have set ourselves to 'look back in order to look forwards'. This IDS Bulletin does that, offering an intellectual history of development and development studies from their emergence in the post-war period - on top of colonial antecedents - through successive eras to the present day. It tracks key continuities around concerns with poverty and social justice, as well as tumultuous changes in intersecting knowledge and practice in rapidly changing times. These bring us up to a present preoccupied by intersecting global challenges and a more universal framing, where development has come to mean - as we put it in our 2015-20 strategy - reducing inequalities, accelerating sustainability and building more inclusive and secure societies for everyone, everywhere. And it highlights many of the issues and uncertainties that lie ahead, to which development and development studies have the opportunity and the responsibility to respond.

Given its focus, it is particularly appropriate that this IDS Bulletin has been assembled and produced by our $\mathrm{PhD}$ students. At early stages in promising careers, they bring the time and ability to reflect deeply on key issues, as well as a unique, forward-looking outlook on the futures that they will help to shape. And by pairing with some of our more senior Fellows in a set of double-acts, they bring lessons from the past as well.

This is, of course, only one history amongst many possible, for histories are always partial. The core focus of this one is the interrelationship between ideas and practices at IDS, and those in the wider field of development and development studies. But even this cannot be a singular history. As the Institute's founder-director, Dudley Seers, argued in 1969, "The starting point in discussing the challenges we now face is to brush aside the web of fantasy we have woven around "development" and decide more precisely what we mean by it'. These words in an IDS Communication titled The Meaning of Development still ring true, and the ongoing, reflexive search for meanings, with ourselves and with people around the world, has been a defining feature of life at IDS ever since. This is only right and proper; debate over meanings amidst multiple perspectives and changing times should be constant, a part of the politics and practices of development, and important to keeping

(C) 2016 The Author. IDS Bulletin () Institute of Development Studies | DOI: 10.19088/1968-2016.127 
it accountable. Inevitably, though, people within and outside IDS have contributed to these debates in different ways and from different positions. The Institute's own history is therefore multistranded, and can be told in multiple ways.

The histories recounted in this IDS Bulletin track some particular themes. One is the transformation of 'development' from an ex-colonial enterprise, and then one formed by the discourses and practices of an aid industry, to embrace far wider processes of capitalist change, the roles of states, markets and societies in them, and the diversity of peoples' accommodations and resistances - both organised and unruly. A second is the transformation of 'development studies' from an era in which IDS could be established in 1966 as a 'special institution' to support the UK government's assistance to its ex-colonies, to a far more networked set of knowledge practices, sensitive to issues of power, representation and difference. As this IDS Bulletin shows, work by IDS researchers and partners has contributed pivotal ideas and debates - around power, gender and ethnicity, for instance - which have helped to shape the last 50 years of development studies. But they have also re-shaped IDS over successive eras into the far more globally-networked institution that it is today, taking an 'engaged excellence' approach to produce and share research and knowledge, teaching and learning, and communications and impact, with questions around the politics of knowledge, practice and difference centre stage.

Third, an abiding theme, well-represented here, is the relationship between analysis and practice. Development studies has always sought to make a difference; its problem-focus explicitly set it aside from ivory towers academia from the start. Again, successive eras have seen more, and more productive, boundary-crossing, whether in work that engages development policymakers and practitioners in reflexive learning and change, that co-constructs knowledge with communities, agencies, businesses and others, or that opens up the possibilities of alternative, potentially transformative, pathways.

The IDS Bulletin has always had a distinctive niche, with its special issues focusing on policy debates of the moment, bridging the contributions and worlds of academics and practitioners. This issue tracks key debates in the fields of agriculture, climate change and social protection, illustrating the kind of contribution for which the IDS Bulletin has become known and welcomed by academics and practitioners alike.

A final theme is the value of Open Knowledge, and Open Access. IDS is committed to an open knowledge agenda that enables perspectives from around the world to be shared, and our relaunch of the IDS Bulletin in 2016 as a gold Open Access publication is a powerful example of this of which I'm especially proud. The final article, recounting some of the Institute's history and forward plans in this area, provides a fitting finale to this issue. I hope you enjoy it all.

Melissa Leach

Director, Institute of Development Studies 


\title{
Introduction: Development Studies - Past, Present and Future
}

\author{
Alia Aghajanian and Jeremy Allouche
}

\begin{abstract}
This introduction article provides a brief history of development studies, including its main challenges and critiques through the years. Based on this, we provide some thoughts on what the future of development studies might look like. There has been a certain continuity of themes in development, with certain ideas coming in and out of fashion. We expect to see more of this trend in the future. We are also hopeful about the necessary global view of development studies, as the Sustainable Development Goals have set the precedent for the move from the 'South' to global development goals. In this article we also provide a short summary of the nine articles in this IDS Bulletin, each tackling the history of a certain topic in development. We draw out the common themes of these development topics, providing complexity, nuance and challenge to existing paradigms.
\end{abstract}

The downtown handicraft market in Accra is bursting with small furniture and trinkets adorned with an ancient Akan symbol, the Sankofa, a bird whose neck is turned backwards and is reaching for an egg placed on its back. The bird represents the importance of looking back, and learning from the past in order to make the best of today as well as the future. One cannot imagine a more fitting lesson for development studies, itself a study of processes and transformations which still appreciates and engages with the nuances and traditions of the past. At 50 years old, the Institute of Development Studies (IDS) is 'looking back, in order to look forward'. This IDS Bulletin tries to do just that, not only by tracing the history of certain topics in development studies, but also by bringing together two generations of scholars, Research Fellows and students, providing insight into our rich past and promising future.

Easily overlooked, the IDS PhD student is an interesting character. After being in a solitary world of reading and writing for one whole year, $\mathrm{PhD}$ students are then allowed to experience, observe and analyse the real world. The idea of this anniversary IDS Bulletin is the result of a mid-term meeting of PhD students with their PhD convenor, Jeremy Allouche. Eager to engage more fully with the wider Institute, the $\mathrm{PhD}$ students decided to take the initiative and envision an IDS Bulletin that 
would bring together students and junior researchers with more senior IDS Research Fellows. The nine articles in this IDS Bulletin represent this collaboration, ${ }^{1}$ forcing $\mathrm{PhD}$ students out of their shells, and making them think about the bigger picture: where has development studies got to today? Where has it come from? And what role has my tiny field of research played in this development of development studies?

Even older than the seemingly endless life of a PhD student is IDS itself! This year we celebrate its 50th Anniversary, and can reflect on how IDS has shaped and continues to shape many powerful ideas within development studies. Some of the key conceptual contributions include: redistribution with growth (Dudley Seers); urban bias (Michael Lipton); structural adjustment with a human face (Richard Jolly); participation (Robert Chambers); and gender and development (Kate Young, Naila Kabeer and others). More recently, programmes on trade and value chains, citizenship, governance, sustainable livelihoods, environmental change and health systems have challenged orthodoxies and thinking in development studies.

Development practitioners have also been another key aspect of IDS' reflexive engagement, with studies such as that by Chambers, Longhurst and Pacey (1981) who highlighted 'tarmac' and 'dry season' bias, where officials and experts tend to visit field sites at times of the most agreeable weather, thus overlooking the harsh environmental realities. In fact, right from the start IDS has been strong at challenging international development aid myths - one of the earliest issues of the IDS Bulletin calls into question how 'we' know what is good for 'them', as pointed out by Jolly (2008). ${ }^{2}$

Today, these IDS traditions continue in our vibrant work across many issues, as we continue to shape development agendas, policy and practice. These include issues around taxation; health and nutrition; gender and sexuality; conflict and violence; resource politics; green transformations; rural futures; and life in cities. We are also extending and connecting our longstanding expertise in state governance and citizen participation by exploring the emerging roles of popular politics, business and markets, and digital technologies in development.

\section{Looking back}

To have an IDS Bulletin on the history of certain ideas, methodologies and themes in development studies, particularly over the last 50 years and highlighting the role that IDS has played, is certainly an ambitious task. This is even more difficult as ideas in development theory and practice cannot be divorced from the broader assumptions, aspirations and beliefs of any age, whether it is the failures of state communism, capitalism and nationalism in the 'Age of Extremes' (Hobsbawm 1994) or today's post-capitalism (Mason 2016).

For us to think about the most influential ideas in development studies, we reflected on the history and meaning of development studies itself. 
The dominant ideas on the nature and genesis of the very process of development have gone through a series of transformations. In the 1950 s, for various political reasons, colonial powers were concerned with the economic progress of the previous colonies. Initially this concern was monopolised by economists and development economists, who had played a major role in the reconstruction of post-war Europe through the Marshall Plan. However, equating progress with economics became increasingly insufficient and limiting, and thus a new multidisciplinary branch of the social sciences was born: development studies.

The overall ideas and theories of development in the early days were in most cases rigid and linear, describing a technological, gendered and monetary evolutionist theory of development (Crewe and Harrison 1998). Whether in modernisation or Marxist theory, technology is seen as an engine of social change, progress and development. Pro-poor technology soon became associated with the idea of intermediate technology (as opposed to high or capital-intensive technology). This push for technological advancement has also led to a gendered bias in development theories and practice as technologies have been associated with men. Finally, economic power, money and materialism have been seen as the major pathway for development. Modernisation and Marxist theories of development became openly criticised after the Cold War, leading some theorists to question the relevance of development studies. In the words of Corbridge, it was 'hopelessly evolutionary, of being colonial in intent, of being masculinist, of being dirigiste, and of being a vehicle for depoliticisation and the extension of bureaucratic state power' (Corbridge 2007: 180). Development studies was reaching a postmodern identity crisis where ideas and concepts had lost any meaning, simply becoming empty buzzwords, leading some to argue that development studies have barely made it to the twenty-first century (Schuurman 2000).

There were, and are still, many uncertainties around the field of development studies. However, the debate has moved on, focusing more on the multidimensional aspects of development and its political nature, and the methodological challenges of being multi- and trans-disciplinary. While the multi-method approach to research provides a more holistic understanding of the topic at hand, some critics believe that the methods taken individually do not live up to the disciplinary standards.

\section{Looking forward}

So what does this very brief intellectual history tell us about looking forward? In some ways, the past influence of evolutionist linear thinking on development studies makes forward thinking a difficult and complex task. Perhaps the most fundamental lesson is that we are talking about a variety and diversity of futures rather than a single linear path. Looking forward could be done in several different ways: what are the new key concepts and ideas? What are the paradigms lost and regained? (This second question contrasts with the first one in that the novelty of these ideas is questioned.) Or finally, are we reaching a new critical juncture in relation to broader transformative changes? 


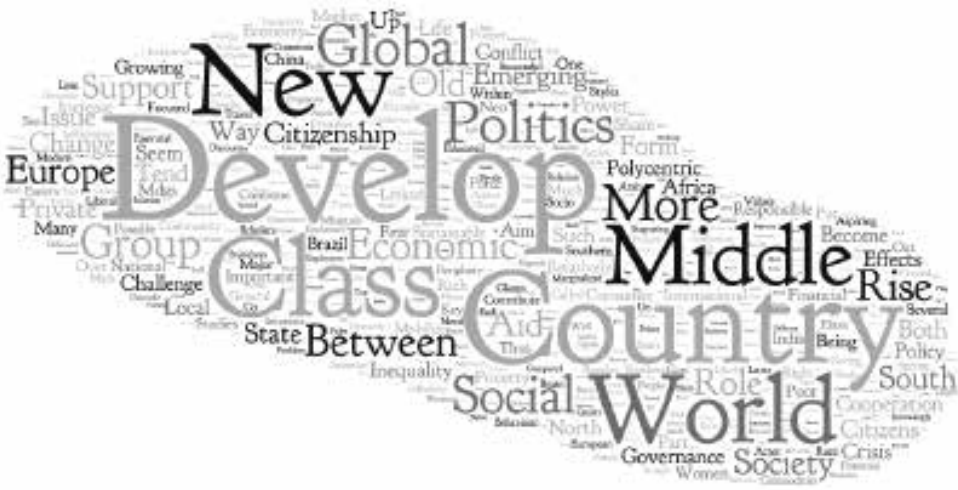

Source Authors' own.

Identifying the new concepts and ideas might seem straightforward. When talking to colleagues, concepts such as complexity, resilience and transformations are seen as the flavour of the day, with some endorsing them while others are openly criticising them. But this may reflect an institutional bias. Another method would be to look at the budget of key international development agencies and see their spending per sectoral theme. The Department for International Development (DFID), for example, has been moving towards allocating and reporting its expenditure by development policy priorities since 2011. Its five pillars were wealth creation; combating climate change; governance and security; the direct delivery of the Millennium Development Goals (MDGs); and global partnerships. Of course, the Sustainable Development Goals (SDGs) will be reflected in the new priorities post 2016. Interestingly, one can see from these priorities that global public goods and partnerships are clearly changing the development landscape priorities and that climate change, the private sector and security are core themes for DFID. Obviously, this is a very limited view of development, illustrating the old paradigm of development as technical aid. Another way to look at it is to analyse the key themes of recent development studies conferences. Figures 1 and 2 illustrate the core themes in the 2014 European Conference on Development Studies and the upcoming 2016 UK Development Studies Association conference in Oxford, respectively.

It becomes obvious that finding a new trend of ideas in development is more difficult than expected. And in fact, these two word clouds show continuity, since words such as politics, power and class are coming back to the forefront. This leads us nicely to our second point.

A second way to think about the future of development is to think about development cycles and paradigms 'lost and regained'. Theories that were popular at the beginning of the twentieth century are being revisited, albeit with more analysis and empirical rigour. For example, with globalisation came the expansion of Western multinational 


\section{Figure 2 Word cloud of core themes from 2016 UK Development Studies Association conference in Oxford}

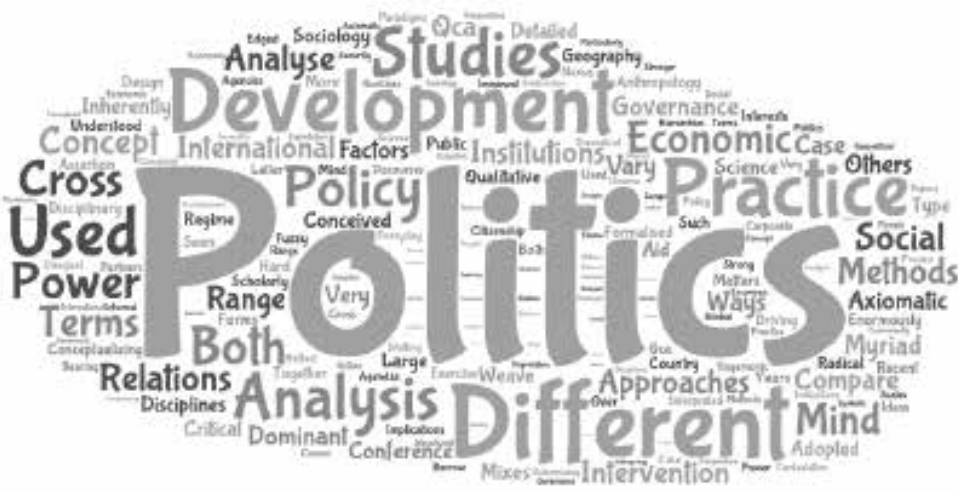

Source Authors' own.

corporations, whose economic power and monopoly in developing countries revived an interest in dependency theory - the idea that rich countries make themselves richer at the expense of the poorer countries. Or more recently, the global financial crisis in 2007-08 was compared to the 1930 financial crisis, and hence one could see the strong return of Polanyi and his idea of Double Movement (1944) in social sciences and development studies. ${ }^{3}$ These patterns make us wonder which lost paradigm, theory or concept may re-emerge in the imminent future.

Our third point is about our understanding and representation of the present era. In our view, this particular moment of time represents a critical juncture in development studies. These paradigm changes, as explained previously, will always be problematic if anchored in viewing development as a North-South issue. Throughout the years, the scope of development studies and development has expanded, and development is not only a concern of the previous colonies, but a global and universal process that aims to better the lives and living standards of people everywhere, as reflected in the SDGs. Of course this should not mean that development tools are applied in the same way universally (Hart 2001). In fact, as shown by many development anthropologists, the global diffusion of this 'regime of truth' of development is very much contested; it either becomes provincialised through cultural encounters (Subramanian 2009), or is localised (and not viewed as culturally foreign) (Pigg 1992). Overall, development, as an idea and practice, is produced and re-produced through existing categories, which it then transforms. International development entails social processes that are inevitably transnational, intercultural, and multi-scalar and involves the interaction and mediation of extensive actor networks, with different logics and world views.

This structural prejudiced framing of development as a North-South issue needs to be removed, and development studies needs to describe and explain social and structural differences that reach across the old 
geographies of the so-called 'North' and 'South'. This paradigm shift is in line with the new universal SDGs, and the IDS strategy for 2015-20, both of which see development in the context of contradictions and complex, globally-interconnected challenges. Development needs to be reframed from narrowly tackling poverty and vulnerability, to navigating complex challenges in ways that reduce inequalities and build more sustainable, inclusive and secure futures for people and societies. We need a universal framing of development that recognises these challenges as matters for everyone, everywhere, from London to Lagos, from South England to the sub-Sahara, and Brighton as well as Beijing.

\section{A selection of topics in development}

This IDS Bulletin brings together nine articles that at first glance seem unrelated. However, in the first place these articles all articulate the development of fields of research and policy in development studies - looking at how far we have come and what the future holds. In accordance to what we have mentioned earlier, the nine articles show that the paths that these topics in development have taken are far from linear. For example, the structural adjustment programmes in the 1980s and 1990s were quite a game changer for social protection and agricultural subsidy policies, but in more recent years we see a reversion to pre-structural adjustment policies that favour a more hands-on approach. Secondly, each of these articles speak to how topics in development studies have critically challenged the existing paradigms, particularly on expanding the focus of development from the 'South' to a universal approach. Thirdly, all of these articles have explored the intersectionality of different aspects to development, say the intersection of climate change and poverty, race and inequality, cities and violence. And finally, reflective of the multidisciplinary approach to development this IDS Bulletin presents a wide range of topics, from gender to urban violence to agriculture input subsidies, documenting how each of these have been tackled using a wide range of research tools, from ethnographies to econometric analysis.

In the first article, Richard Jolly and Ricardo Santos take a look at the colonial roots of development, documenting how it was initiated post-Second World War when developed countries tried to fight underdevelopment in the 'third world'. The belief that the policies and practices of the rich and powerful Western world can and should be applied elsewhere describes much of the thinking about development up to the present time. Wade (2004) and Chang (2002) were instrumental in changing this belief and contesting the idea that Western economic success was due to liberalised policies (the most convincing evidence was the success of the 'Asian Tigers'). Jolly and Santos provide an interesting narrative of IDS' role in these debates, particularly through Bienefeld (1992), Chambers (2008), Kabeer (2006), Lipton (1977), Seers (1967), Jolly (2008) and other researchers who have been or are currently Fellows at IDS.

While Jolly and Santos' article gives a great overview of the development discourse, the next three articles focus on the evolution of 
certain development policies and practices: agricultural input subsidies, climate change policies and social protection. This is followed by four articles focusing on ideas in development: violence and cities, power, gender, and ethnicity. The last article critically discusses the use of Open Access research as a way to disseminate research, ideas and policy recommendations universally.

Tamahi Kato and Martin Greeley focus on a particular agricultural policy that has been popular in sub-Saharan Africa since the 1970s: subsidising agricultural inputs, such as fertiliser and seeds. The agricultural sector is significantly large in developing countries, and subsidies were seen as direct support to poorer farmers, a way to drive down high food prices, and a direct channel to poorer voters. However, the financial burden that subsidies placed on governments, in addition to qualitative evidence of elite capturing, left the policy community divided regarding subsidy programmes. While their popularity had dwindled by the 1990s, following the structural adjustment programmes of the International Monetary Fund (IMF) and World Bank, there has been a re-emergence of 'new and improved' input subsidy programmes since the 2000s. This article evaluates five new input subsidy programmes in Malawi, Zambia, Ghana, Nigeria and Tanzania. In addition, an indepth analysis of an input subsidy programme in Tanzania is provided, courtesy of the $\mathrm{PhD}$ research of one of the co-authors, Tamahi Kato. This article summarises much needed evidence for the debate which has remained contentious throughout the history of development studies: are the efficiencies of free markets superior to the helping hand of the government through state-controlled policies?

The pertinence of climate change today is undeniable. Changing sea-levels and drastic changes to the climatic environment have become hard to ignore, and countries have recently pledged to reduce climate change at COP2 $1 .{ }^{4}$ However, the path to mitigating climate change is less clear. In an example of how development studies challenges existing world views, Rachel Godfrey-Wood and Lars Otto Naess warn us that the focus on adaptation to climate change should not mean that policymakers focus only on incremental treatments of the symptoms of climate change, but in fact a more drastic approach that tackles the root causes of climate change, and the intersectionality between climate change effects and vulnerability. This has resulted in the use of the term 'transformation', rather than adaptation and resilience, or even mitigation in the first place (Ribot 2011; Pelling, O'Brien and Matyas 2015; Tschakert et al. 2013; Bahadur and Tanner 2014). Despite the popularity of 'transformation' in academic circles, Godfrey-Wood and Naess argue that its operationalisation remains unclear, unless accompanied by a political and institutional change along the lines of Tschakert et al. (2013) and Feola (2015).

Social protection was originally a development policy applied in developed countries, taking the form of social security, unemployment benefits and pensions - all redistributive policies aiming to benefit 
the population during times of hardship. Stephen Devereux and Ana Solórzano trace the development origins of social protection to the provision of insurance after income insecurity caused by structural adjustment programmes and other events such as war and famine. One of the most famous and researched social protection programmes is the Oportunidades in Mexico, which has provided grants since the late 1990s, conditional on children attending school and health clinic visits. The success of this programme saw the rise of conditional cash transfers around the developing world, and was seen as a major steppingstone to trying to achieve the MDGs (Fiszbein, Kanbur and Yemtsov 2014). However, as summarised by Devereux and Sabates-Wheeler (2007), the popularity of such programmes led to a critical ideological debate: is social protection a human right, or is it a vehicle to help the poor manage risk? And if so, should social protection be conditional on certain indicators of 'good behaviour'? Devereux and Solórzano provide a fascinating and critical account of IDS' contribution to this debate, to the conceptualisation of social protection, to its implementation, and finally on how to evaluate its success.

Jaideep Gupte and Hadeer Elshafie explain that while IDS' contribution to the fields of cities and urbanisation is relatively sparse (albeit Michael Lipton's (1977) Urban Bias thesis), there is much scope for its development, particularly among a group of up-and-coming researchers at the Institute. DFID has recently described cities and urbanisation as the 'new frontier' for development (DFID 2010). More than half the world currently live in urban areas, and this is expected to increase to two thirds by 2050. In addition, the share of the poor living in urban areas is rising, at a much faster rate than the share in the population as a whole. These new statistics have forced development studies, and IDS, to rethink the urban bias thesis, and reconsider urban studies as an essential part of development. Recently, research has shown that violence is disproportionately located in urban areas (Buhaug and Urdal 2013), and disproportionately affects the urban poor and vulnerable (Justino 2007). Work at IDS has focused on this nexus between cities and violence, understanding how people adapt when exposed to violence as part of the everyday realities of urban life, from Kingston, Jamaica (Pearce, McGee and Wheeler 2011) to Maharashtra, India (Gupte, Justino and Tranchant 2014).

Today, power relations are recognised as embedded within development studies, bringing up crucial questions about power dynamics: who bestows power and who receives it? Who holds knowledge, who passes it on and to whom? And who has the agency? However, this reflective thinking has not always been an integral part of development. Looking back through old issues of the IDS Bulletin, Maro Pantazidou and John Gaventa find that the early references to power refer to economic capital or institutional systems of power, such as 'oil power' (Maull 1976) or a 'monopoly of power' (Brett 1987). However, this view was challenged towards the 1990s and a new approach to power emerged, which focuses on the experience and actions of the relatively powerless, 
accounts for the power dynamics in complex social relationships, and recognises how knowledge production can contribute to and reflect those power relationships. The IDS approach to power led to a fundamental change in the development approach, advocating for participatory, rights-based approaches and empowering the disempowered. This work was pioneered by IDS Research Fellows Robert Chambers and John Gaventa, but currently permeates into all research and practice conducted at IDS, and is represented in IDS' commitment to transforming all types of inequalities and building inclusive societies.

The emergence of gender as an important factor in development can be partly attributed to a group of IDS Masters students who advocated for the appointment of Kate Young in 1977 as an IDS Gender Research Fellow. Zahrah Nesbitt-Ahmed and Jenny Edwards provide a fascinating account of how Kate Young struggled to claim her space even within IDS at the time. IDS has been at the forefront of gender issues and development since the 1980s, initiating the first Masters of Arts in Gender and Development jointly with the University of Sussex, and challenging male bias in the production of knowledge in development studies, which often led to gender-insensitive and dangerous development practices. The 2000s saw the emergence of sexuality and 'pleasure-based development', which challenges the hetero-normative development approach which excludes those who are already marginalised because of their sexuality. IDS has also recently started to shape the discourse around masculinities, calling for gender-sensitive analysis to the 'structural implications of male privilege' (Nesbitt-Ahmed and Edwards, this IDS Bulletin).

Ethnicity theory has evolved from its origins, which assumed ethnicity was a permanent fixture, to acknowledging the more fluid and dynamic role that ethnicity can play regarding self-identity and perceptions of others, and the agency individuals have in constructing their own ethnicity and identity. While the complexity and nuances of ethnic identity are now recognised, Naysan Adlparvar and Mariz Tadros argue for the importance of the intersectionality of ethnicity, and have highlighted some key contributions from IDS in terms of the interconnectedness of ethnicity with development policy, citizenship, violence, health and sexuality, volunteering and interethnic relations. The pertinence of ethnicity and interethnic relations and its influence on development outcomes and practices cannot be ignored, and there is still a need to further research this link.

Hani Morsi and Alison Norwood end this IDS Bulletin with an article on Open Access research, and its implications for development studies and the IDS Bulletin in particular. As some of the other articles in this IDS Bulletin have shown, the production of knowledge in development has profound implications for its practice. In particular, who has access to this knowledge? At the heart of IDS work is the bottom-up approach, and as researchers here we try to make the voices of the poor, marginalised and disempowered, heard. But that is only one step in the process. This knowledge should not be exclusive to those who 
are comfortably situated within the libraries of their ivory towers, but readily available and accessible to everyone, particularly those who will be most affected by its concluding policies. In 2016 the IDS Bulletin became Open Access: its articles that challenge prevailing development discourses, advocate for inclusive policies and participatory approaches, and represent the nuances and complexities of different experiences and identities, are now free for all to access and use.

\section{Notes}

1 Some authors will have graduated by the time of publication. In addition, among the junior authors is an IDS Research Officer (although at the time of publication a Research Fellow), and an ex-Masters student.

2 While these are only a few snapshots of key intellectual contributions from the Institute, we urge readers who are interested to learn more to take a look at $A$ Short History of IDS: A Personal Reflection, written by IDS Emeritus Fellow and contributor to this IDS Bulletin, Sir Richard Jolly (2008). Richard provides an excellent account of the history of IDS, one of the first institutes in the world dedicated to development studies, and the unique challenges it has faced throughout different British governments, changing world views and narratives, and global events, throughout standing as strong as it does today.

3 This idea of Double Movement refers to a dialectical process of marketisation and push for social protection against that marketisation.

4 The 2015 United Nations Climate Change Conference, Paris.

\section{References}

Bahadur, Aditya and Tanner, Thomas (2014) 'Transformational Resilience Thinking: Putting People, Power and Politics at the Heart of Urban Climate Resilience', Environment and Urbanization 26.1: 200-14, DOI:10.1177/0956247814522154

Bienefeld, M. (1992) Rescuing the Dream of Development in the Nineties, Silver Jubilee Paper, Brighton: IDS, http://agris.fao.org/agrissearch/search.do?recordID=GB9137445 $($ accessed 10 March 2016)

Brett, E.A. (1987) 'States, Markets and Private Power in the Developing World: Problems and Possibilities', IDS Bulletin 18.3: 1-7, http://bulletin.ids.ac.uk/idsbo/article/view/1964 (accessed 12 April 2016)

Buhaug, Halvard and Urdal, Henrik (2013) 'An Urbanization Bomb? Population Growth and Social Disorder in Cities', Global Environmental Change 23.1: 1-10, DOI:10.1016/j.gloenvcha.2012.10.016

Chambers, Robert (2008) Revolutions in Development Inquiry, London: Earthscan

Chambers, Robert; Longhurst, Richard and Pacey, Arnold (eds) (1981) Seasonal Dimensions to Rural Poverty, London: Frances Pinter Ltd Chang, Ha-Joon (2002) Kicking Away the Ladder?: Economic Development in Historical Perspective, London: Anthem Press

Corbridge, Stuart (2007) 'The (Im)Possibility of Development Studies', Economy and Society 36.2: 179-211 
Crewe, Emma and Harrison, Elizabeth (1998) Whose Development?: An Ethnography of Aid, London: Zed Books

Devereux, Stephen and Sabates-Wheeler, Rachel (2007) 'Editorial Introduction: Debating Social Protection', IDS Bulletin 38.3: 1-7, http://bulletin.ids.ac.uk/idsbo/article/view/836 (accessed 10 March 2016)

DFID (2010) Cities: The New Frontier, London: Department for International Development, www.gov.uk/government/publications/ cities-the-new-frontier (accessed 10 March 2016)

Feola, Giuseppe (2015) 'Societal Transformation in Response to Global Environmental Change: A Review of Emerging Concepts', Ambio 44.5: 376-90, DOI:10.1007/s13280-014-0582-z

Fiszbein, Ariel; Kanbur, Ravi and Yemtsov, Ruslan (2014) 'Social Protection and Poverty Reduction: Global Patterns and Some Targets', World Development 61: 167-77, DOI:10.1016/j.worlddev.2014.04.010

Gupte, Jaideep; Justino, Patricia and Tranchant, Jean-Pierre (2014) 'Households amid Urban Riots', Fournal of Conflict Resolution 58.8: 1445-73, DOI:10.1177/0022002714547886

Hart, G. (2001) 'Progress Reports Development Critiques in the 1990s: Culs de Sac and Promising Paths', Progress in Human Geography 25.4: 649-58

Hobsbawm, E. (1994) The Age of Extremes: The Short Twentieth Century, 1914-1991, London: Penguin

Jolly, Richard (2008) A Short History of IDS: A Personal Reflection, IDS Discussion Paper 388, Brighton: IDS, www.ids.ac.uk/publication/ a-short-history-of-ids-a-personal-reflection (accessed 11 March 2016)

Justino, Patricia (2007) On the Links Between Violent Conflict and Household Poverty: How Much Do We Really Know?', SSRN Scholarly Paper ID 1116265, Rochester NY: Social Science Research Network, http:/ / papers.ssrn.com/abstract=1116265 (accessed 11 March 2016)

Kabeer, Naila (2006) 'Poverty, Social Exclusion and the MDGs: The Challenge of "Durable Inequalities" in the Asian Context', IDS Bulletin 37.3: 64-78, http://bulletin.ids.ac.uk/idsbo/article/ view/955 (accessed 11 March 2016)

Lipton, M. (1977) Why Poor People Stay Poor: A Study of Urban Bias in World Development, London: Temple Smith

Mason, P. (2016) Postcapitalism, London: Penguin Books

Maull, Hanns (1976) 'The Preconditions for Producer Power: The OPEC Example', IDS Bulletin 7.4: 27-8

Pearce, J.; McGee, R. and Wheeler (2011) Violence, Security and Democracy: Perverse Interfaces and Their Implications for States and Citizens in the Global South, IDS Working Paper 357, Brighton: IDS

Pelling, Mark; O'Brien, Karen and Matyas, David (2015) 'Adaptation and Transformation', Climatic Change 133.1: 113-27, DOI:10.1007/s10584-014-1303-0

Pigg, Stacy Leigh (1992) 'Inventing Social Categories through Place: Social Representations and Development in Nepal', Comparative Studies in Society and History 34.3: 491-513

Polanyi, K. (1944) The Great Transformation, New York NY: Rinehart 
Ribot, Jesse (2011) 'Vulnerability before Adaptation: Toward Transformative Climate Action', Global Environmental Change 21.4: 1160-2, DOI:10.1016/j.gloenvcha.2011.07.008

Schuurman, Frans J. (2000) 'Paradigms Lost, Paradigms Regained? Development Studies in the Twenty-first Century', Third World Quarterly 21.1: 7-20

Seers, Dudley (1967) The Meaning of Development, IDS Communication 44, Brighton: IDS, www.ids.ac.uk/files/dmfile/themeaningofdevelopment.pdf (accessed 11 March 2016)

Subramanian, Ajantha (2009) Shorelines: Space and Rights in South India, Stanford CA: Stanford University Press

Tschakert, Petra; van Oort, Bob; Lera St. Clair, Asuncion; and LaMadrid, Armando (2013) 'Inequality and Transformation Analyses: A Complementary Lens for Addressing Vulnerability to Climate Change', Climate and Development 5.4, DOI:10.1080/17565529.2013.828583

Wade, Robert (2004) Governing the Market: Economic Theory and the Role of Government in East Asian Industrialization, 2nd ed., Princeton NJ: Princeton University Press 


\title{
From Development of the 'Other' to Global Governance for Universal and Sustainable Development
}

\author{
Richard Jolly and Ricardo Santos
}

\begin{abstract}
This article traces the evolution of the ideologies and narratives that have framed 'development' since its post-Second World War inception, through growth and dependency, adjustment and human development, state to market, to more equitable and globally supported sustainable development strategies required for the post-2015 decades. It analyses the ideas that became the main contributors to a multipolar and still contested narrative of national and global development, highlighting what can be learned from the process that led to current perspectives and goals for sustainable development.
\end{abstract}

The article focuses especially on contributions by the Institute of Development Studies (IDS) and its global partners, both as critic of dominant orthodoxies and as creator or supporter of alternatives. It ends with reflections on the adequacy of the current narratives and perspectives in light of the challenges facing a multipolar, interconnected and interdependent world, and conclusions about future directions for thinking, action and research.

\section{Introduction}

In the wake of the Second World War and with the approaching independence of most African and many Asian nations from European colonisation, a concept, a mandate and a path started to take shape. The concept was the development of the 'underdeveloped countries' of the world, renamed in the 1960s the 'Third World' and more recently the 'developing countries'. The mandate was for 'developed' nations, the rich Western economies of Europe and the new world economic powerhouse, the United States (US), to create the conditions to fight 'underdevelopment' in other nations in the world. The 'Third World' could only reach the levels of 'First World Development' by following what, with some re-invention of history, was said to have been the development steps of those that had first walked the same path. 
From President Truman's inaugural speech in 1949, Walt Rostow's The Stages of Economic Growth: A Non-Communist Manifesto in 1960, the International Labour Organization's Employment, Growth and Basic Needs (ILO 1976) in the 1970s and Our Common Future, the Report of the World Commission on Environment and Development (WCED 1987) in the 1980s, the objectives and narratives that defined 'development' changed dramatically. By 2000, Human Rights had been made an integral part of Human Development - and the Millennium Development Goals (MDGs) had been set and endorsed by the United Nations (UN). Many of these components are now found in the universal Sustainable Development Goals (SDGs), adopted in 2015 by all 193 UN member states.

In considerable contrast to these dominant and Western intellectual formulations, actual economic and social advance proceeded along diverse paths, depending on the time and place. Different success stories, from Japan to the 'Asian Tigers', to the BRICS (Brazil, Russia, India, China and South Africa) and Rising Powers, called into question the idea of 'one path'. The collapse of communism dealt a major blow to countries trying the state-led planned economy route. At the same time, the failures of the Washington Consensus, implemented in the 1980s and early 1990s through the conditionalities of structural adjustment programmes in the 1980s, resulted in a 'lost decade' for Africa and Latin America. These failures also cast doubt whether the 'Western recommended path' could achieve the more pragmatic successes of Asia (Korea, Taiwan, Malaysia, Singapore and, more recently, China) as highlighted by Wade (1990) and Lin (2014). Recently, increasing evidence of climate change and growing awareness of planetary boundaries shows clearly that no previous path will be adequate for the challenges of the future (Raworth 2012). There is thus a growing realisation that sustainable development on a worldwide scale cannot be pursued without fundamental changes by all major actors, of each country's own path and in the structures of international global governance supporting - or obstructing - its achievement.

This short review revisits early reflections originating in the Institute of Development Studies (IDS) on these changing development narratives and the role academic research and thought from within it contributed to the debate, supporting, critiquing or warning against the adoption of dominant orthodoxies. It draws particularly on Bienefeld (1992), Ferguson (1998), Thorbecke (2000) and Jolly (2008).

\section{The inception of a voluntarist 'development' dream}

In his critique, Rist (2007) suggests that, from inception, 'development' was an empty concept, a 'public relations gimmick' coined to add some originality to President Truman's inaugural speech. However rhetorical it may have seemed, the speech expressed an optimistic view that 'underdeveloped' countries and peoples could aspire to modernisation and the living conditions of people in 'developed' countries. And within the UN, the effect was positive and electrifying. Hans Singer, then 
employed as one of the UN's first economists, rushed to redraft the UN's budget for technical assistance with a proposal for an Expanded Programme of Technical Assistance (EPTA), giving the entire UN an operational role (Shaw 2002).

Industrialisation, as Thorbecke (2000) points out, was the core of the first main strategy of 'development'. The proposed method, partly inspired by the reconstruction of Western Europe, under the Marshall Plan, and the strong industrialisation of the USSR (ibid.), was also motivated by contemporaneous concepts of critical minimum levels of investment. Theories like Rosenstein-Rodan's 'Big Push' (1943) and Rostow's 'Stages of Growth' (1956) played a significant role in framing these early policies, even supported by anthropological studies on cultural obstacles to economic 'take-off' (Geertz 1963a, b). ${ }^{1}$ With a focus on economic growth, economic theories, policy objectives, strategies and practice of development agencies, all aimed to support investment in the industrial sector as the pathway to development.

These were periods of optimism. In the wake of the Second World War, an era of political decolonisation and consistent and stable economic growth in both 'capitalist' and 'Soviet' blocs suggested that at least one of the competing paths would lead 'underdeveloped' nations to 'development'. Somewhat ignoring the weak administrative starting points in many developing countries, the notion of 'development' soon filled the vision and ambitions of leaders of independence as well as of many others wanting to build a fairer, better world. As Fred Bienefeld, one of the early IDS Fellows, put it:

The dream was human liberation - from poverty and want, from oppression, from violence, from the drudgery of monotonous and stultifying work. The dream was of life in stable communities, rich in human relations, secure, materially prosperous and focused on leisure undertaken for their own sake and not for instrumental reasons (Bienefeld 1992: 3).

The dominant objective of the 1960s and 1970s was economic growth, led by government planning in both Western and Soviet-influenced countries, though with state direction in the latter and much use of the market in the former. It was Dudley Seers, the first director of IDS, who questioned whether growth was enough to fulfil the desired improvements in the living conditions of people in poorer nations. Having earlier been the first director general of the UK's recently created Ministry of Overseas Development (now called Department for International Development, DFID), Seers voiced these concerns and mapped out tests for a wider perspective of development:

The questions to ask about a country's development are therefore: What has been happening to poverty? What has been happening to unemployment? What has been happening to inequality? If all three of these have declined from high levels, then beyond doubt this has 
been a period of development for the country concerned. If one or two of these central problems have been growing worse, especially if all three have, it would be strange to call the result 'development', even if per capita income doubled (Seers 1969).

The importance of an employment focus and an equitable growth path towards poverty reduction was also stressed in the first three reports of the ILO Employment Missions, in all of which IDS played a leading role (Colombia 1970, Sri Lanka 1971 and Kenya 1972). ${ }^{2}$ Each report applied these objectives to the specifics of the countries concerned. From these emerged the IDS/World Bank study, Redistribution with Growth (Chenery et al. 1974), in which the examples of redistributive growth were sought in developing countries and were drawn from the very inadequate data of the time. More influential - and more acceptable politically at the time - was the concept of development strategy directed to the fulfilment of Basic Needs, ${ }^{3}$ which also grew out of the recommendations of the Kenya ILO mission but which was brought together and formulated more analytically in ILO's Employment, Growth and Basic Needs: A One-World Problem (1976). For the last few years of the 1970s, basic needs became development orthodoxy.

The contributions from IDS to alternative thoughts on 'development' in the 1960s and 1970s went well beyond macro-economic strategy. They included the much debated and often cited study by Michael Lipton, 'Why Poor People Stay Poor: A Study of Urban Bias in World Development' (1977). The first examples of pioneering work on participatory methodologies for action and research can be found in the late 1970s with Rapid Rural Appraisals (Chambers 2008: 68). IDS came late to issues of gender and women in development, until Kate Young (1979) established the Subordination of Women programme, launched in two mobilising conferences held at IDS in 1979 (see also NesbittAhmed and Edwards, this IDS Bulletin). ${ }^{4}$ IDS research and teaching identified three alternative paradigms for development analysis: the structuralist, the neoliberal and the Marxian, with some IDS Fellows working within each, though with different degrees of pragmatism in their analysis.

In hindsight, a missing dimension from the three questions of Dudley Seers emerged in the UN's Conference on the Environment, held in Stockholm in 1972. The planet that had hosted a Space Race and landed a man on the moon in 1969 was dangerously nearing the destruction of its own environment. Barbara Ward, one of the early IDS trustees (then called governors), had aptly captured the global challenge in her book Spaceship Earth (1966). This was carried much further 20 years later in Brundtland et al.'s path-breaking report of the WCED, Our Common Future (WCED 1987). By the mid-1980s, hardly three decades from the launch of the development enterprise, the path taken by the world economies, led by those claiming to be 'developed', had brought to the fore a fundamental question: is the planet capable of sustaining these developments? 
The age of optimistic belief in investment-driven, economic growth, supported by 'developed countries', began to wane in the 1970s. A three and a half-fold increase in oil prices in 1973/4 brought the richest countries to their knees and world economic growth shuddered to a halt ${ }^{5}$ - though with the OPEC oil-exporting countries surging in new-found income and wealth. For a short while, developing countries saw the chance for a new global deal - a New International Economic Order (NIEO). At IDS, Reg Green and Hans Singer even spelt out a way forward: 'Toward a Rational and Equitable New International Economic Order: A Case for Negotiated Structural Changes' (Green and Singer 1975). ${ }^{6}$ But the realpolitik of rich country interests and ideas became the order of the day. After a year or two of apparent North-South negotiations, serious talk of NIEO was dead. Instead, the banks of the North had found a way to recycle the oil-generated surpluses from the OPEC countries, the so-called 'petro-dollars', into whichever country wanted them and was prepared to borrow to pay. Any idea of the NOPEC countries - Singer's phrase for the developing countries without oil - directly receiving a share of OPEC income as payment for supporting the OPEC cartel had gone out the window. NOPEC countries borrowed heavily and their debt rose along with price inflation worldwide, setting the stage for the Bretton Woods-led structural adjustment programmes of the 1980s and the lost decade for development in Africa and Latin America - though not in Asia.

\section{Economic crisis in the 'West' turns the 'dream' into 'nightmare'}

Again, the 'development' impetus was drawn from an idealised version of a 'path of righteousness' imposed by the richest economies: 'do as I (claim to) have done'. In the 1980s, mainstream 'development policy' began to advocate 'fiscal conservatism'. Milton Friedman was advocating a monetarist strategy for the US, and over two or three years his rules for strictly controlling the supply of money were seriously implemented in the UK by the new Thatcher government. After some disastrous experiences, these were abandoned, though neoliberal economic policies remained. ${ }^{7}$ In the US, under President Reagan, neoliberal policies were applied more pragmatically. All this created worldwide a newly acquired faith in (or forced conversion to) markets and neoliberalism.

In Latin America and Africa, action to reduce the debt forced serious changes. Basic Needs went out the window, helped in the World Bank by the retirement of Robert McNamara, their great proponent and early defender of poverty-reducing strategy. The shift in strategy was furthered in the case of sub-Saharan Africa by the World Bank's report, Accelerated Development in Sub-Saharan Africa: An Agenda for Action (Berg 1981), drafted mostly by Elliot Berg but with more pragmatic interpolations by others. This neatly shifted the blame in African countries from external factors - debt and the failures of NIEO - to internal failures, especially of government-led action as opposed to reliance on the market and private sector. Also in the Bank's sights was the Lagos Plan of Action, the first truly Africa-born strategy prepared by 
the UN Economic Commission for Africa (ECA) and African ministers of planning and endorsed by heads of state and government for the Economic Development of Africa 1980-2000. ${ }^{8}$ It is still worth reading for its long-term perspectives and political-economic strategy. At IDS, Reg Green wrote a devastating critique of the Berg Report, noting parallels with the book of Genesis, with different sources and authors for different parts of its argument (Green and Allison 1984).

Mainstream orthodoxy - in the West and forced on Africa and Latin America but not in Asia - now looked to the private sector to take up roles that weak and highly indebted governments of new nations had yet fully to assume. The new global pathway to 'development', particularly in the Western 'capitalist' hemisphere, was 'structural adjustment'. Aid was made conditional on implementing policies laid down by the World Bank and the International Monetary Fund (IMF), and mostly also coordinated with the larger donors. Governments of developing countries were no longer seen as the natural engines of industrialisation and growth but as mistrusted over-spenders, needing to be disciplined. Structural adjustment policies cut back on all forms of government spending and on developing governments themselves. ${ }^{9}$ This underlying mistrust of national governments gave rise to a second effect: the increase in the perceived importance of non-governmental organisations (NGOs) as those "better prepared to work with the "poorest of the poor"" (Riddell 2007). Arguably, these two new instruments continued the paternalistic vision that underlay much 'development' from inception, albeit taken one step further. Not only were 'developing' nations to follow the (imagined) footsteps of the 'developed', their institutions were not to be trusted in pursuing the 'right initiatives'. They needed to be conditioned into better practices or even replaced by (international) civil society in assisting the poor and excluded in their societies.

The effects were dismal at best, especially for living standards and public services (Cornia, Jolly and Stewart 1987). The recrudescence of humanitarian crises and the continuing indebtedness of ever-shrinking public systems revealed the failures of a solution that had pushed Africa and Latin America into what is now considered a lost decade.

In contrast to the recipes of the Washington Consensus, the countries of South East Asia stood out as 'shining examples'. These were the 'Asian Tigers', originally hailed as examples of free-market success. After careful research by IDS Fellow Robert Wade, they proved to be notable deviants from orthodoxy - as analysed in his much praised book, Governing the Market: Economic Theory and the Role of Government in East Asian Industrialization (1990). Leadership by a strong state could be combined with the market and with strong export orientation. Other Fellows also worked together at the same time to produce a more general theoretical and operational volume, States or Markets: Neo-Liberalism and the Development Policy Debate (Colclough and Manor 1993). This restored balance to an often polarised debate: excessive intervention and price distortions had held back development, but 
equally a simple ideologically-driven turn to free-market economics was also over-simple and dangerous. At a higher level of generalisation, through this book IDS challenged the narrow orthodoxies of the 1980s and put forward a more balanced view.

The narrow-minded mainstream policies of the 1980s and 1990s should not obscure the various ways in which IDS thinking proposed alternatives to the adjustment remedies. In the early 1980s, after Richard Jolly had joined UNICEF, a first publication was issued, 'The Impact of World Recession on Children' (Jolly and Cornia 1984), which was prepared by an international group that included Hans Singer and dedicated to Dudley Seers who had died in May 1983. This led to further challenges to orthodoxy, notably at the global conference of the Society of International Development (SID) ${ }^{10}$ in 1985 where Jolly presented the Barbara Ward memorial lecture on 'Adjustment with a Human Face'. Two years later, UNICEF issued a major research study, Adjustment with a Human Face (Cornia et al. 1987), widely distributed in three languages. At IDS, the new director, Mike Faber, with Reg Green ran a succession of studies on alternatives to structural adjustment, supported in part by the World Bank.

By 1990, it was clear that many structural adjustment programmes had failed to achieve their objectives. The blame initially was placed on the developing countries themselves - for not having properly implemented the programmes or not having stuck with them for long enough or for some other reason. ${ }^{11}$ This orthodox focus gradually shifted to blaming weaknesses in their administration and the need for strengthening governance and introducing democracy. Strengthening democracy also accorded with Western political policy after the collapse of the USSR.

At IDS, a Governance Team was formed in 1991/02, initially critiquing the emerging donor agenda and putting forward positive ideas for 'Good Governance' (Robinson and Moore 1993). This work developed further and more widely over the next decade or two, researching in detail issues of taxation, finance and the environment, each with particular attention to how smaller groups within countries were being affected, or more often neglected, in the international drive for improving governance.

\section{Governance, globalisation and environment - focused on smaller groups}

One of the more original parts of IDS' work in the 1990s grew out of Mick Moore's work on Taxation, which explored and then demonstrated how the form of public revenue was a major determinant of the quality of a country's governance. Starting in the 1990s and ahead of the curve, this has today become a mainstream development issue, underlying a shift from an aid-centric to a tax-centric debate on resource mobilisation. IDS' focus on economic organisation in developing countries led to research on spreading the gains from globalisation, with the central proposition that the way an economy is organised has major repercussions on the speed and quality of growth, the accumulation of capabilities and the distribution of gains. 
Finance was also (and continues to be) the central focus of the work of Stephany Griffith-Jones, who contributed to research and policy suggestions on how to make the domestic and international financial system more stable so that it can better serve the needs of inclusive economic development and the real economy. In 'The Growth of Multinational Banking, the Euro-Currency Market and their Effects on Developing Countries' (Griffith-Jones 1980), she warned of the risk of excessive international bank lending to developing economies. Her book, Debt and Development Crises in Latin America: The End of An Illusion (Griffith-Jones and Sunkel 1986), showed the negative effects of the 1980s Latin American debt crisis on the region's economic development. Griffith-Jones was an early advocate of debt relief in Latin America and sub-Saharan Africa.

The collective efficiency of small producers was another element which had a major influence on the ability of local enterprises to compete in the global economy. This line of research transformed the research and policy agenda on small-scale industry and the informal sector. The analysis of global value chains was a second line of pioneering work, involving John Humphrey, Raphie Kaplinsky, Hubert Schmitz, Khalid Nadvi, Stephanie Barrientos and Adrian Wood, as well as graduate students and partnerships with Duke University and the Massachusetts Institute of Technology (MIT). The central insight was that the way trade was organised was critical and had major repercussions: on access to markets, prospects for upgrading, distribution of gains and possibilities for successful policy interventions. The importance of this work was that it challenged the triumphalism of export-success globalisation by arguing that the key issue was not whether a country should participate in globalisation but how it should do so. This work was well disseminated through an international conference in 1999, with high-level participation from the World Bank and the UN, a special issue of World Development, an article, 'The Governance of Global Value Chains' (Gereffi, Humphrey and Sturgeon 2005), and several books including Value Chain Analysis for Policy Makers and Practitioners (Schmitz 2005) and Globalization, Poverty and Inequality: Between a Rock and a Hard Place (Kaplinsky 2013).

The work on global value chains led to research on the major shifts in global power and the Asian Drivers Research programme, formally started in 2005, though with recognition of the issues well before this. While the theme is now mainstream, at the time it was ahead of the curve. Now under the Rising Powers and Global Governance programme, IDS seeks to explore the increasing influence of the BRICS and other rapidly changing middle- or low-income countries. In this way, IDS is advocating a restructuring of global development institutions and the governance of global public goods (such as the environment, food and health).

The environment was another area where, in the 1990s, IDS critiqued mainstream thinking and moved research into exploring more positive 
alternatives. Community-based natural resource management was by then a popular approach in environmental circles. Melissa Leach, Ian Scoones and others shared the ambition but showed how practical implementation often fell short of expectations, especially by neglecting intra-community dynamics and the specifics of context, given that ecologies are so heterogeneous. Central to this work was a focus on sustainable livelihoods, which again showed how often mainstream approaches produced systematic 'pathologies' by too narrowly focusing on 'impact'. The IDS environment group then moved on to deal with institutions and uncertainty and paid more attention to the dynamics of ecology. By the mid-2000s, these issues had been brought together in the STEPS programme focused on Social, Technological and Environmental Pathways to Sustainability.

Some of these themes were common to IDS' work on participation, originated and sustained since the 1970s by Robert Chambers, but moving in the 1990s into various forms of Participatory Rural Appraisal and farmer participatory research. John Gaventa carried much of this work further with more attention to power and politics applied to Citizenship, which redefined the agenda for research and policy.

\section{Towards universal and multidimensional objectives of global development}

Globally, the 1990s offered another significant contribution to reflections on development as a multidimensional process, social as well as economic, political and cultural. This was through the Human Development Reports (HDR), the creation of Mahbub ul Haq under the sponsorship of the United Nations Development Programme (UNDP 1990) and with strong philosophical underpinnings from Amartya Sen, who earlier had analysed development in terms of strengthening human capabilities and expanding people's choices. Mahbub ul Haq had long followed the work of IDS and Amartya Sen had been a governor in the 1970s. In 1996 Richard Jolly took over from Mahbub as the Principal Coordinator of the HDR and oversaw reports on human development and economic growth, poverty, consumption and globalisation. The 2000 report on Human Development and Human Rights analysed the links between them, especially what human development adds to human rights and what human rights adds to human development (UNDP 2000).

The advent of the new millennium provided fertile ground for a much broader and multidimensional approach to development to take hold. Kofi Annan, Secretary-General of the UN, issued a major document, We the Peoples: The Role of the United Nations in the 21st Century (UN 2000). This gold-covered document provided the background for the Millennium Declaration, adopted by governments at the Millennium Summit attended by 149 heads of state and government and senior representatives of another 40 countries. The Declaration is an impressive document, much broader than the still-important but more narrowly-focused MDGs.

The years since 2000 have witnessed what arguably has been the world's most ambitious project of coordinated action on multidimensional deprivations, the MDGs. Initially criticised for being little more 
than an international set of 'good intentions' devised by those that claimed success in the 'development process' and bestowed upon those that were still 'developing', the MDGs offered, nonetheless, basic goals and a common language. Time would reveal the MDGs as an instrumental yardstick against which the Rising Powers, particularly China, would defend the success of their own development pathways, affirming alternative narratives on how to proceed in the future. This is particularly noticeable in The Quest for Prosperity by Justin Lin (2014), where he delineates a Chinese-inspired path for 'developing' economies to find prosperity. The MDGs have also provided a frame of goals against which the successes and failures, triumphs and shortfalls could be and were measured and publicised by the UN. There is, of course, much that can be criticised about the MDGs, perhaps especially the reductionist tendency of the World Bank, the media and many others to concentrate almost entirely upon the goal of reducing poverty and economic growth as the main means towards it. The 'dollar a day' indicator of poverty is also seriously inadequate. ${ }^{12}$

In spite of all these inadequacies, the MDGs achieved sustained global attention and were followed up by many countries. IDS was often involved at the country level in helping to critically review progress. ${ }^{13}$ As 2015 approached, it was clear that the MDGs had achieved considerable progress (UN 2015) and governments and a vast number of civil society groups became engaged in the formulation of what should follow. These have become the SDGs, adopted by governments at the UN in September 2015. As before, there is much that can be criticised - though they now encompass, in our view, major advances on the MDGs. The SDGs are universal, applying to all countries. They have been assembled through an unprecedented process of participation, country by country, often with strong civil society participation, in countries of the South as well as in the North. In their diversity and multiplication, the new SDGs appear to have answered concerns of representation. They are the first global set of policies to have truly been originated from the contributions of multiple actors, stepping beyond the 'ivory towers' of 'developed' countries' wisdom or top-down UN leadership.

These are major virtues, in our view, far outweighing their oft-derided number: 17 goals, 169 targets and 304 indicators. As each country is required to adapt the goals to their own situation and set national priorities - in consultation with civil society organisations - these seem narrow criticisms, ${ }^{14}$ compared to the remarkable achievement of all the nations formally agreeing on goals and targets for future development.

\section{The post-2015 development agenda - will the SDGs be enough or is something completely different required?}

A growing awareness of the earth's planetary boundaries, through evidence of climate change, shows clearly that all development paths need fundamental change. No previous path provides adequate guidance for the challenges of the future. New technologies as well as new directions and political alliances are needed. Global sustainable 
development cannot be pursued without fundamental changes by all major actors, of each country's own development structure and path, as well as strengthening the structures of international global governance in support of them. The concept of 'development' itself requires fundamental changes.

Moreover, at the time of writing, many regions of the world are torn by war and civil strife, often aligned with religious and other factions. The global economy has been slowing, with the institutions of global governance weak in their capacity to command consensus, let alone to mobilise action. The multinational corporations seem able to increase their monopolistic dominance in markets throughout the world, with mostly inadequate efforts of governments to exert control let alone to levy reasonable contributions to national taxation.

The future for development needs to be framed by five fundamental objectives - universalism, sustainability, equity, human development and human rights. All five are embodied in the SDGs, an important advance as well as a formal political endorsement, internationally and nationally, even if with varying levels of commitment by the majority of the world's countries.

First, Universalism. This is a great advance, as it removes the longstanding weakness of development, where for 50 years, people from the North prescribed desirable solutions to problems faced by people in the South. In our view, universalism does not mean a total change of content and agenda but a broadening of context and application. It also means, as Dudley Seers demonstrated in his own work during his last ten years, that development experts will use approaches and techniques developed in and for developing countries and apply them in and for developed countries (Seers 1980; Seers, Schaffer and Kiljunen 1979). For many development specialists (though by no means all) universalism may also bring a welcome change of attitude - no longer lording it over others as experts but relating to those in policy positions in a more questioning, learning and empathetic way, recognising the social and political complications which often constrain doing what we experts think is obviously desirable. It may also help strengthen the political economy analysis of strategy and policy action.

What might a more universal development agenda mean for research and teaching? Bringing together analysis of development in so-called developing countries with analysis in so-called developed countries would broaden both approaches. It would combine attention to comparative work in developed countries, with more attention to context and institutions - and long-run changes - and perhaps to the political economy of policy proposals. One can only be surprised and somewhat appalled at the narrow national focus of economic policy debate in the UK, which is so often limited to UK issues with little, if any, attention given to the experience and policy approaches of other countries in Europe, let alone of countries beyond. 
For developing countries, and for teaching in institutions like IDS, a universal approach would deal with one of the curious weaknesses of teaching - bringing students from the South to the North to learn about how to analyse problems and reach policy conclusions in their own countries. IDS students complained about this in the 1970s. In response, Dudley Seers took the students to Scotland to help analyse the consequences of new discoveries of North Sea oil (M.Phil Faculty 2012) and also got policymakers from Norway and Venezuela to share their experiences. This is an example of a new approach, well ahead of the changes which a more universal agenda for development and analysis would bring.

Sustainability. The challenges to achieve sustainability are to keep resource use within the external boundaries of planetary sustainability while ensuring enough production to meet the human needs of the world's population. Many have shown that with reasonable distribution this could be feasible (Leach, Raworth and Rockström 2013; Raworth 2012). Yet at the moment, the needs of the poor and marginalised are mostly seen in poor countries and in rich as requiring more economic growth, both to generate more employment and more taxation to ensure the finance required to create more social services, especially for the youngest and oldest sections of the population. With the older sections of the population increasing in many parts of the world, the implications of this human approach to long-run sustainability are often neglected in the focus on environmental issues and survival of the planet, which though vital, is only part of the total problem. Both elements of sustainability must be explored, and both will require serious challenges to ever-growing consumption among the better-off sections of the population in both rich and poorer countries.

Equity. Inequality has at last been put centre stage, especially thanks to the work of Piketty (2014) and the econometric work of Berg and Ostry (2013) of the IMF. The opportunity of working on inequality must not be missed, because the forces of opposition to action will not remain sidelined for long, even though the extremes of income inequality within countries are at unprecedented levels. Already the dramatic reductions of Gini coefficients in the majority of Latin America countries, as shown by Cornia (2014) and López-Calva and Lustig (2010), are slowing and sometimes being reversed.

The work by Richard Wilkinson and Kate Pickett (2009) is also an important reminder that inequality must be analysed in a multidimensional manner and brought into mainstream policy. The Spirit Level shows ten dimensions of wellbeing where inequality has a major impact on mental illness, child and adult mortality, obesity, educational performance, teenage births, homicide, imprisonment rates, levels of trust and social mobility. Wilkinson increasingly believes that the common factor behind these many and widespread repercussions of inequality is stress - and a reminder that the future universal agenda of human development must encompass a wide range of multidisciplinary 
work. Naila Kabeer's (2010) IDS publication on intersecting inequalities explores a range of issues which merit further research.

Human Development. The human development (HD) paradigm has its own stimulating richness and subtleties. But it needs to be pursued within the framework of capabilities, functionings and choices as so brilliantly set out by Amartya Sen (1999), now also backed up by many others like Martha Nussbaum, Des Gasper, Ingrid Robeyns and Sakiko Fukuda-Parr. ${ }^{15}$ The fact that some 140 countries have produced their own national HDRs is a further example of its widespread application.

Yet one must note that HD is still rarely part of mainstream work, either in the teaching of development or as a frame for policy analysis and policymaking, even among the UN agencies. Human development theory, techniques and applications need to be brought into development teaching, as well as into policy studies and consultancies. This would be an important step towards offsetting the narrow applications of neoliberal economic teaching and policymaking - and the narrowness of austerity policies being promoted across Europe today. As Mahbub ul Haq put it in the 1992 HDR, it is illogical and absurd to think that one can restore balance to a country's economy by unbalancing the lives of its people. Human development analysis is also a better frame for considering the unique problems of different categories of people, perhaps especially today of older people, and how to strengthen their capabilities for the choices that make sense in their stages of life.

Human Rights. Human Rights is not separate from Human Development but integral, although not identical, to it. As Sen has shown, human rights add international legitimacy and a process of law to concern for human rights (Sen 1999; UNDP 2000). Human development adds analysis and experience of national institutions, structures and experiences of how countries can advance economically and socially in development in ways which combine respect for human rights with human rights fulfilment. There are implications for both policy and research, examples for policy in how this has been done and research as to the positives and negatives of these situations and the political economy and costs and benefits of lessons for other countries in the future.

\section{Conclusion}

The above objectives set an international agenda of goals, to which every country needs to take action. For the poorer and least developed countries, international support is still generally required. But for middle-income and richer countries - even the richest - international action and stronger global governance is also required if the world is to ensure a peaceful, inclusive and stable frame within which all nations can advance. As part of this, international regulation and initiatives are needed to ensure the provision of 'global public goods' in such key areas as guarding against the transmission of disease, attacks on cyber-security, as well as moving towards new global policies to control migration and to ensure fairer regimes for trade and technology development. 
All these have important implications for development teaching and research in bodies like IDS. Universality means a broadening of teaching and research to apply development thinking and research from developing countries to problems in the so-called developed countries - and vice versa. The paradigm of Human Development includes the concept of human security and humane global governance. Work on the SDGs in all countries requires support for the process of democratic priority-setting at all levels of policymaking and implementation as well as professional assistance in the processes of review, monitoring and accountability of them, especially by support of regional peer reviews of progress and summary assessments of progress to high-level UN fora. More attention to inequality will involve a wider multidisciplinary approach throughout the whole range of human development concerns, policies and actions.

There will be more than enough work for development professionals in the future - and the shift of focus and broadening of coverage and development approaches will enliven and energise the next generation of committed development professionals. There will be no lack of issues on which IDS can research and teach, increasingly in partnership with others around the world. May the Institute continue to challenge simplistic and self-interested orthodoxies and remedies, to promote a bold and humane global vision, and through research contribute to actions which help and encourage progress towards it.

Whose language brings forth our world and guides our actions? Who defines what words mean? The world brought forth is usually constructed by the powerful in central places or by those well placed to influence them. The words and concepts of development both express and form the mindsets and values of dominant linguistic groups, disciplines and professions, and organisations (Chambers 1997: 1746 quoted in Cornwall and Scoones 2011: 80).

\section{Notes}

1 As noted by Ferguson (1998).

2 For a summary of the ILO Kenya Mission, see Singer and Jolly (1973). A shortened version is included in Jolly (2012: 121-34).

3 'Basic needs' were defined by ILO as comprising two elements: (1) Certain minimum requirements of a family for private consumption: adequate food, shelter and clothing, and also certain household equipment and furniture; and (2) Essential services provided by and for the community at large such as safe drinking water, sanitation, public transport and health and educational facilities (ILO 1976: 32).

4 See also Milestones and Turning Points (Jolly 2012: 237-42).

5 World GDP did not record any growth in 1975.

6 A shortened version is given in Jolly (2012: 278-95).

7 John Kenneth Galbraith described Friedman as having received the compliment of being one of the few economists whose policies were almost perfectly implemented - and found not to work! 
8 See Adedeji (2004). His chapter goes on to describe the Elliot Berg report under the heading of 'Battle for the African Mind'.

9 There is a vast literature on structural adjustment. On the impact on African politics see Herbst (1990).

10 At which Dudley Seers had first presented his views on the meaning of development.

11 In 2007 James Raymond Vreeland reviewed a vast collection of studies on explanations for failures of adjustment policies and concluded that they had a strongly negative and statistically significant impact on economic growth in the long run. As he put it, 'the newly emerging consensus is that IMF adjustment policies hurt economic growth' (Vreeland 2007: 90).

12 Actually the indicator for the World Bank at the time of writing, 2016 , is US\$1.90, a still narrow and inadequate measure, though widely used and dominating internationally.

13 For some notable examples see Bossert (2005), Jolly (2010), Kabeer (2006), Manning (2010), Pollard et al. (2011) and Vandemoortele and Delamonica (2010).

14 See for example, Vandemoortele (2014, 2016).

15 See Fournal of Human Development and Capabilities, www.tandfonline.com/ toc/CJHD20/current.

\section{References}

Adedeji, A. (2004) 'The ECA: Forging a Future for Africa', in Yves Berthelot (ed.), Unity and Diversity in Development Ideas: Perspectives from the UN Regional Commissions, Bloomington IN: Indiana University Press

Berg, E. (1981) Accelerated Development in Sub-Saharan Africa: An Agenda for Action, Washington DC: World Bank

Berg, A.G. and Ostry, J.D. (2013) 'Inequality and Unsustainable Growth: Two Sides of the Same Coin?', International Organisations Research fournal 8.4: 77-99

Bienefeld, Manfred (1992) Rescuing the Dream of Development in the Nineties, IDS Silver Jubilee Papers, Brighton: IDS

Bossert, T. (2005) 'Reaching the Health MDGs with Human Resource Reforms: Financial, Educational and Management Capacities', IDS Bulletin 36.3: 74-82, http://bulletin.ids.ac.uk/idsbo/article/ view/1008 (accessed 4 March 2016)

Chambers, R. (2008) Revolutions in Development Inquiry, Abingdon: Earthscan

Chambers, R. (1997) 'Editorial: Responsible Well-being - A Personal Agenda for Development', World Development 25.11: 1743-54

Chenery, H.; Ahluwalia, M.; Bell, C.L.G.; Duloy, J.H. and Jolly, R. (1974) Redistribution with Growth: Policies to Improve Income Distribution in Developing Countries in the Context of Economic Growth, Oxford: Oxford University Press

Colclough, G. and Manor, J. (1993; reprinted 2000) States or Markets? NeoLiberalism and the Development Policy Debate, Oxford: Clarendon Press

Cornia, G.A. (2014) Falling Inequality in Latin America: Policy Changes and Lessons, WIDER Studies in Development Economics, Oxford: Oxford University Press 
Cornia, G.A.; Jolly, R. and Stewart, F. (1987) Adjustment with a Human Face: Protecting the Vulnerable and Promoting Growth, Oxford: Clarendon Press

Cornwall, A. and Scoones, I. (2011) Revolutionizing Development: Reflections on the Work of Robert Chambers, Abingdon: Earthscan

Ferguson, J. (1998) 'Anthropology and its Evil Twin: "Development" in the Constitution of a Discipline', in F. Cooper and R. Packard (eds), International Development and the Social Sciences: Essays on the History and Politics of Knowledge, Berkeley CA: University of California Press

Geertz, C. (1963a) Peddlers and Princes: Social Development and Economic Change in Two Indonesian Towns, Chicago IL: University of Chicago Press

Geertz, C. (1963b) Agricultural Involution: The Process of Ecological Change in Indonesia, Berkeley CA: University of California Press

Gereffi, G.; Humphrey, J. and Sturgeon, T. (2005) 'The Governance of Global Value Chains', Review of International Political Economy 12.1: 78-104

Green, R.H. and Allison, C. (1984) The Bank's Agenda for Accelerated Development: Dialectics, Doubts and Dialogues, http://opendocs.ids. ac.uk/opendocs/handle/123456789/4812\#.Vsttj0Dp5HI (accessed 22 February 2016)

Green, R.H. and Singer, H.W. (1975) 'Toward a Rational and Equitable New International Economic Order: A Case for Negotiated Structural Changes', World Development 3.6: 427-44, DOI:10.1016/0305-750X(75)90028-5, www.researchgate.net/ publication/4763597_Toward_a_rational_and_equitable_new_ international_economic_order_A_case_for_negotiated_structural_ changes (accessed 22 February 2016)

Griffith-Jones, S. (1980) 'The Growth of Multinational Banking, the Euro-Currency Market and their Effects on Developing Countries', Journal of Development Studies 16.2: 204-23

Griffith-Jones, S. and Sunkel, O. (1986) Debt and Development Crises in Latin America: The End of an Illusion, Oxford: Clarendon Press

Herbst, J. (1990) 'The Structural Adjustment of Politics in Africa', World Development 18.7: 949-58, DOI: 10.1016/0305-750X(90)90078-C, www.researchgate.net/publication/223010623_The_Structural_ Adjustment_of_Politics_in_Africa (accessed 22 February 2016)

ILO (1976) Employment, Growth and Basic Needs: A One-World Problem; The International 'Basic-Needs Strategy' Against Chronic Poverty, and the Decisions of the 1976 World Employment Conference, Washington DC: International Labour Organization and Overseas Development Council

Jolly, R. (2012) Milestones and Turning Points in Development Thinking, London: Palgrave Macmillan

Jolly, R. (2010) 'The MDGs in Historical Perspective', IDS Bulletin 41.1: 48-50, http://bulletin.ids.ac.uk/idsbo/article/view/532 (accessed 4 March 2016)

Jolly, R. (2008) A Short History of IDS: A Personal Reflection, IDS Discussion Paper 388, Brighton: IDS, www.ids.ac.uk/publication/a-short-historyof-ids-a-personal-reflection (accessed 11 March 2016) 
Jolly, Richard and Cornia, Giovanni Andrea (eds) (1984) 'The Impact of World Recession on Children', World Development 12.3, Special Issue, March

Kabeer, N. (2010) 'Can the MDGs Provide a Pathway to Social Justice? The Challenge of Intersecting Inequalities', Child Poverty and Inequality: New Perspectives: 57-62, www.unicef.org/socialpolicy/ files/Child_Poverty_Inequality_FINAL_Web_web.pdf (accessed 22 February 2016)

Kabeer, N. (2006) 'Poverty, Social Exclusion and the MDGs: The Challenge of "Durable Inequalities" in the Asian Context', IDS Bulletin 37.3: 64-78, http://bulletin.ids.ac.uk/idsbo/article/ view/955 (accessed 4 March 2016)

Kaplinsky, R. (2013) Globalization, Poverty and Inequality: Between a Rock and a Hard Place, Cambridge: Polity

Leach, M.; Raworth, K. and Rockström, J. (2013) 'Between Social and Planetary Boundaries: Navigating Pathways in the Safe and Just Space for Humanity', World Social Science Report: 84-9

Lin, J.Y. (2014) The Quest for Prosperity: How Developing Economies can Take Off, Princeton NJ: Princeton University Press

Lipton, M. (1977) 'Why Poor People Stay Poor: A Study of Urban Bias in World Development', Scandinavian Fournal of Economics 80.3: www.researchgate.net/publication/259759897_Why_People_Stay_ Poor_Urban_Bias_in_World_Development (accessed 1 March 2016)

López-Calva, L.F. and Lustig, N. (2010) Declining Inequality in Latin America: A Decade of Progress?, New York NY: United Nations Development Programme (UNDP)

Manning, R. (2010) 'The Impact and Design of the MDGs: Some Reflections', IDS Bulletin 41.1: 7-14, http://bulletin.ids.ac.uk/idsbo/ article/view/548 (accessed 4 March 2016)

M.Phil Faculty (2012) 'Are Development Studies Relevant to British Problems?', in R. Jolly (ed.), Milestones and Turning Points in Development Thinking, London: Palgrave Macmillan: 28-42

Piketty, T. (2014) Capital in the Twenty-First Century, Cambridge MA: Harvard University Press

Pollard, A.; Sumner, A.; Polato-Lopes, M. and de Mauroy, A. (2011) '100 Voices: Southern NGO Perspectives on the Millennium Development Goals and Beyond', IDS Bulletin 42.5: 120-3, http://bulletin.ids.ac.uk/idsbo/article/view/393 (accessed 4 March 2016)

Raworth, K. (2012) A Safe and Just Space for Humanity: Can We Live Within the Doughnut?, Oxfam Discussion Paper, Oxford: Oxfam, http:/ / policy-practice.oxfam.org.uk/publications/a-safe-andjust-space-for-humanity-can-we-live-within-the-doughnut-210490 (accessed 23 February 2016)

Riddell, R.C. (2007) Does Foreign Aid Really Work?, Oxford: Oxford University Press

Rist, G. (2007) 'Development as a Buzzword', Development in Practice 17.4/5: 485-91 
Robinson, M. and Moore, M. (1993) 'Good Government', IDS Bulletin 24.1, http://bulletin.ids.ac.uk/idsbo/issue/view/123 (accessed 8 April 2016)

Rosenstein-Rodan, P.N. (1943) 'Problems of Industrialization of Eastern and South-Eastern Europe', Economic Fournal 53.210/211: 202-11

Rostow, W.W. (1960) The Stages of Economic Growth: A Non-Communist Manifesto, Cambridge: Cambridge University Press

Rostow, W.W. (1956) 'The Take-Off into Self-Sustained Growth', Economic fournal 66.261: 25-48

Schmitz, H. (2005) Value Chain Analysis for Policy Makers and Practitioners, Geneva: International Labour Organization (ILO)

Seers, D. (1980) 'Theoretical Aspects of Unequal Development at Different Spatial Levels', in Dudley Seers and Marja-Liisa Kiljunen (eds), Integration and Unequal Development: The Experience of the EEC, London: Macmillan: 9-23

Seers, D. (1969) 'The Meaning of Development', International Development Review 11.4: 3-4

Seers, D.; Schaffer, B. and Kiljunen, M.-L. (1979) Underdeveloped Europe: Studies in Core-Periphery Relations, Hassocks: Harvester

Sen, A. (1999) Development as Freedom, Oxford: Oxford University Press

Shaw, D.J. (2002) Sir Hans W. Singer: The Life and Work of a Development Economist, London: Palgrave

Singer, H.W. and Jolly, R. (1973) 'Unemployment in an African Setting: Lessons of the Employment Mission to Kenya', International Labour Review 107.2: 103-15

Thorbecke, E. (2000) 'The Evolution of the Development Doctrine and the Role of Foreign Aid, 1950-2000', in F. Tarp (ed.), Foreign Aid and Development: Lessons Learnt and Directions for the Future, London: Routledge

UN (2015) The Millennium Development Goals Report 2015, New York NY: United Nations

UN (2000) We the Peoples: The Role of the United Nations in the 21st Century, New York NY: United Nations

UNDP (2000) HDR 2000 - Human Rights and Human Development, New York NY: United Nations Development Programme

UNDP (1990) HDR 1990 - Concept and Measurement of Human Development, New York NY: United Nations Development Programme Vandemoortele, J. (2016) 'SDGs Indicators: More About Politics than Statistics', Deliver2030.org, blog, http://deliver2030.org/?p=6738 (accessed 22 February 2016)

Vandemoortele, J. (2014) 'Post-2015 Agenda: Mission Impossible?', Development Studies Research 1.1: 223-32

Vandemoortele, J. and Delamonica, E. (2010) 'Taking the MDGs Beyond 2015: Hasten Slowly', IDS Bulletin 41.1: 60-9, http://bulletin.ids.ac.uk/idsbo/article/view/534 (accessed 4 March 2016)

Vreeland, J.R. (2007) The International Monetary Fund: Politics of Conditional Lending, London and New York NY: Routledge 
Wade, R. (1990) Governing the Market: Economic Theory and the Role of Government in East Asian Industrialization, Princeton NJ: Princeton University Press

Ward, B. (1966) Spaceship Earth, Harmondsworth: Penguin

WCED (World Commission on Environment and Development) (1987) Our Common Future, Oxford: Oxford University Press

Wilkinson, R.G. and Pickett, K. (2009) The Spirit Level: Why More Equal Societies Almost Always Do Better, London: Allen Lane

Young, K. (1979) 'The Continuing Subordination of Women in the Development Process', IDS Bulletin 10.3: 14-37 


\title{
Agricultural Input Subsidies in Sub-Saharan Africa
}

\author{
Tamahi Kato and Martin Greeley
}

Abstract The Institute of Development Studies (IDS) has contributed to African agricultural policy debate which has featured prominently in growth and poverty reduction assessment in sub-Saharan Africa. This debate has rekindled interest in the use of agricultural input subsidies to promote food security nationally and at household level. After the enforced withdrawal of these agricultural subsidies during the structural adjustment era, their re-introduction as 'market-smart' subsidies has led to several assessment studies. This article draws on evidence from five countries and a detailed study in Ruvuma Region, Tanzania. These subsidy programmes were reported to be successful in increasing maize yields and reducing poverty and had positive spillover effects on input use by non-recipients and private sector development in rural areas. However, unclear programme objectives and serious implementation problems prevented most of these programmes from being effective. These results underline the controversial nature of subsidy policies, with contemporary debate mirroring historical controversy.

\section{Introduction}

Development theory has built on the historic experience of rich countries to identify a foundational role for agricultural growth in national economic development. The policy implications of this role have been controversial and the Institute of Development Studies (IDS) has made seminal contributions to this central development debate, notably through the publications of Michael Lipton (e.g. Lipton 1968, 1977, 1989 and 1991). Much of the controversy has centred on the role of agricultural subsidies. Key actors, especially the international financial institutions, have supported different policies - in favour of subsidies and then opposed - in response to shifting ideological influence and the contestation between state and market. IDS (e.g. Colclough and Manor 1991) was deeply involved in the critique of neoliberal orthodoxy which advocated an unhealthy dependence on market-based solutions to development problems. Policy debates were especially vehement in the 1980s in sub-Saharan Africa (SSA) which experienced the enforced adoption of structural adjustment, including the withdrawal of agricultural subsidies along with a wide range of market-based agricultural policies. 
Agricultural input subsidies are again contentious today in policy debate over 'market-smart' subsidies, making this a particularly pertinent topic to explore in this IDS Bulletin. This article examines the use of agricultural subsidies policies through an analysis of design and implementation issues in five SSA countries before drawing on a detailed Tanzanian case study. It provides policy conclusions relevant to the current enthusiasm for 'market-smart' subsidies.

In the years before the mid-1970s, a number of SSA countries developed food security programmes by providing subsidised inputs, farm credit, extension services and marketing facilities to farmers as well as by controlling markets and food crop prices (Maxwell 2001). These subsidies supported nationalistic policies by providing direct support to farmers and were seen as a key tool for development through agricultural intensification. However, subsidies also represented a huge financial burden (Chirwa and Dorward 2013; Jayne and Rashid 2013). Their effectiveness has become increasingly questioned due to capture by wealthier farmers (Pan and Christiaensen 2012; Ricker-Gilbert and Jayne 2012). Due to the fiscal unsustainability and inefficiency of these state-controlled policies, structural adjustment programmes were introduced in the agricultural sector in the 1980s and 1990s. These programmes created liberalised input and output markets with the abolition of pan-territorial prices, the privatisation of state-owned enterprises and the removal of input subsidies. Although a positive growth rate of agricultural gross domestic product (GDP) per capita has been reported since then, food crop yields have been stagnant in the region (World Bank 2007). One of the reasons for this low productivity has been the low level of input use (Crawford, Jayne and Kelly 2006).

Subsidy programmes have been popular among politicians since they provided direct support to rural voters and 'compensate(d) for the lack of longer-term investment for infrastructure and short-cut the need for more complex coordination efforts for market development' (Poulton, Dorward and Kydd 2009: 1416). Subsidy programmes were continued in Malawi and Zambia, justified on the basis of the threat of food insecurity from drought and a stagnant economy. Since the early 2000s, other SSA countries have also gradually reintroduced input subsidy programmes using resources generated through debt cancellation under the HighlyIndebted Poor Countries (HIPC) initiative and General Budget Support.

The reintroduction of input subsidies often caused considerable tension between government and donors. The main opponents cited a history of inefficiencies due to mismanagement and fraud. However, the donors' positions varied over time and were not consistent even within the same institutions (Potter 2005; Chirwa and Dorward 2013), due either to differing ideologies or to the lack of evidence available as to the effects and efficiency of the subsidies.

At least eight countries have introduced or reintroduced input subsidies in the region (Crawford et al. 2006; Druilhe and Barreiro-Hurle 2012). 
These input subsidies have evolved from demonstration packs to large subsidy programmes, but have mainly shifted to targeting small-scale farmers, as in Kenya, Malawi, Rwanda, the United Republic of Tanzania, Zambia, Mozambique, Nigeria and Ghana ${ }^{1}$ (Druilhe and Barreiro-Hurle 2012; Liverpool-Tasie 2012b). We focus here on 'market-smart' subsidies, targeting small-scale farmers and promoting private sector development. Evidence shows that these subsidies have increased fertiliser use, average food crop yields and food crop production. But success depends on the context, and their design and implementation features (Dorward and Kydd 2005; Druilhe and Barreiro-Hurle 2012; Chirwa and Dorward 2013).

Input subsidies have been contentious. Opponents suggest that they are too expensive and suffer from fraud and mismanagement (World Bank 2007: 115; Ricker-Gilbert, Jayne and Shively 2013: 1). In addition, they tend to benefit wealthier farmers the most, rather than poor farmers, creating a widening gap between these two groups (Ricker-Gilbert and Jayne 2012). Proponents suggest that they educate farmers on input use and, if used properly, will develop the private sector which will give farmers better access to inputs (Crawford et al. 2006; Minot and Benson 2009; Chirwa and Dorward 2013). This article provides a review of the features and effects of these new subsidies. We first review five input subsidy programmes in Malawi, Zambia, Ghana, Nigeria and Tanzania, as these countries conducted the principal 'market-smart' subsidy programmes in SSA. We then focus on a case study carried out using mixed methods in Ruvuma Region in the Southern Highlands of Tanzania, which is a 'high-potential area' for input use. We conclude with an overview of the challenges posed by these programmes and opportunities for their strengthening.

\section{Overview of five 'market-smart' subsidy programmes in SSA}

\subsection{Design and implementation of 'market-smart' input subsidies}

Contemporary agricultural subsidy programmes generally have two objectives: (1) to increase national food security and accelerate economic growth through increased maize/rice production; and (2) to reduce poverty among small-scale farmers by improving household food security through increased production from increased use of inputs (Chirwa and Dorward 2013; Ricker-Gilbert et al. 2013). Targeting small-scale farmers explicitly supports the second objective and perhaps increases the effectiveness of the programme by increasing input use, given that these farmers generally had not used inputs before the programme. ${ }^{2}$

In aiming to overcome the past deficiencies of input subsidies, 'market-smart' input subsidies: (1) target small-scale vulnerable farmers who did not use inputs before but are expected to find it profitable to do so; (2) promote private sector development, where the private sector procures and distributes inputs by using vouchers, matching grants and loan guarantees; and (3) have an 'exit' strategy, because of their huge financial burden on governments and because of their possible contribution to market distortion (Morris et al. 2007; Chirwa and 
Vol. 47 No. 2 May 2016: 'Development Studies - Past, Present and Future'

Table 1 Characteristics of five input subsidy programmes in sub-Saharan Africa

\begin{tabular}{|c|c|c|c|c|c|}
\hline & Malawi & Zambia & Ghana & Tanzania & Nigeria \\
\hline Programme & $\begin{array}{l}\text { Farm Input } \\
\text { Subsidy } \\
\text { Programme }\end{array}$ & $\begin{array}{l}\text { Farm Input } \\
\text { Subsidy } \\
\text { Programme }\end{array}$ & $\begin{array}{l}\text { Fertiliser Subsidy } \\
\text { Programme }\end{array}$ & $\begin{array}{l}\text { National } \\
\text { Agricultural Input } \\
\text { Voucher Scheme }\end{array}$ & $\begin{array}{l}\text { Growth } \\
\text { Enhancement } \\
\text { Support Scheme }\end{array}$ \\
\hline Year implemented & 2005/06 & 2009 & 2008-13, 2015 & 2008/09-2013/14 & 2012 \\
\hline $\begin{array}{l}\text { Programme } \\
\text { objectives }\end{array}$ & $\begin{array}{l}\text { Improve resource- } \\
\text { poor smallholder } \\
\text { farmers' access to } \\
\text { improved inputs in } \\
\text { order to achieve } \\
\text { household and } \\
\text { national food self- } \\
\text { sufficiency, and } \\
\text { raise incomes }\end{array}$ & $\begin{array}{l}\text { Improve } \\
\text { household and } \\
\text { national food } \\
\text { security, incomes, } \\
\text { and small-scale } \\
\text { farmers' access to } \\
\text { agricultural inputs }\end{array}$ & $\begin{array}{l}\text { Enhance national } \\
\text { food production } \\
\text { and security }\end{array}$ & $\begin{array}{l}\text { Reduce poverty } \\
\text { and household } \\
\text { food insecurity as } \\
\text { well as achieve } \\
\text { economic growth } \\
\text { and national food } \\
\text { security }\end{array}$ & $\begin{array}{l}\text { Promote fertiliser } \\
\text { demand and } \\
\text { private input } \\
\text { sector }\end{array}$ \\
\hline Targeted crop & $\begin{array}{l}\text { Maize, legumes, } \\
\text { and other cash } \\
\text { crops (reverting } \\
\text { to maize and } \\
\text { legumes only since } \\
\text { 2009/10) }\end{array}$ & Maize & $\begin{array}{l}\text { Maize or rice, and } \\
\text { legumes (soya } \\
\text { bean) }\end{array}$ & Maize or rice & Maize or rice \\
\hline $\begin{array}{l}\text { Targeted } \\
\text { beneficiaries }\end{array}$ & $\begin{array}{l}\text { Smallholder } \\
\text { farmers, with } \\
\text { female-headed } \\
\text { households a } \\
\text { priority }\end{array}$ & $\begin{array}{l}\text { Small-scale } \\
\text { farmers (less than } \\
5 \text { ha) }\end{array}$ & $\begin{array}{l}\text { Smallholder food } \\
\text { crop farmers } \\
\text { (maize, rice, } \\
\text { sorghum and } \\
\text { millet) }\end{array}$ & $\begin{array}{l}\text { Small-scale } \\
\text { farmers (less than } \\
\text { 1ha, although } \\
\text { this criterion } \\
\text { was eliminated } \\
\text { in 2010) able } \\
\text { to pay for and } \\
\text { use inputs with } \\
\text { female-headed } \\
\text { households as a } \\
\text { priority }\end{array}$ & $\begin{array}{l}\text { Smallholder } \\
\text { farmers }\end{array}$ \\
\hline $\begin{array}{l}\text { Beneficiary } \\
\text { selection } \\
\text { mechanism }\end{array}$ & $\begin{array}{l}\text { Varied with } \\
\text { time - through } \\
\text { traditional } \\
\text { authorities, varied } \\
\text { stakeholders, } \\
\text { village } \\
\text { development } \\
\text { committees, open } \\
\text { meetings for } \\
\text { allocation led by } \\
\text { the Ministry of } \\
\text { Agriculture and } \\
\text { Food Security }\end{array}$ & $\begin{array}{l}\text { Cooperative } \\
\text { boards, extension } \\
\text { officers, and } \\
\text { local leaders } \\
\text { are involved in } \\
\text { selection }\end{array}$ & Extension officers & $\begin{array}{l}\text { Village voucher } \\
\text { committee }\end{array}$ & $\begin{array}{l}\text { Farmer } \\
\text { registration }\end{array}$ \\
\hline Subsidy delivery & Coupons & $\begin{array}{l}\text { Farmer } \\
\text { cooperatives } \\
\text { (piloted } \\
\text { e-voucher) }\end{array}$ & Coupons & Voucher & $\begin{array}{l}\text { E-voucher } \\
\text { through mobile } \\
\text { phone }\end{array}$ \\
\hline
\end{tabular}


Table 1 Characteristics of five input subsidy programmes in sub-Saharan Africa (cont.)

\begin{tabular}{|c|c|c|c|c|c|}
\hline & Malawi & Zambia & Ghana & Tanzania & Nigeria \\
\hline $\begin{array}{l}\text { Subsidised input } \\
\text { package }\end{array}$ & $\begin{array}{l}50 \mathrm{~kg} \text { of fertiliser } \\
+2-4 \mathrm{~kg} \text { of seeds }\end{array}$ & $\begin{array}{l}200 \mathrm{~kg} \text { of fertiliser } \\
+10 \mathrm{~kg} \text { of maize }\end{array}$ & $\begin{array}{l}\text { No standard } \\
\text { package } \\
\text { (compound } \\
\text { fertiliser + urea) }\end{array}$ & $\begin{array}{l}100 \mathrm{~kg} \text { of fertiliser } \\
+10 \mathrm{~kg} \text { of seeds }\end{array}$ & $\begin{array}{l}100 \mathrm{~kg} \text { of fertiliser } \\
+ \text { seeds }\end{array}$ \\
\hline Subsidy amount & $\begin{array}{l}\text { About } 64-93 \text { per } \\
\text { cent of input cost }\end{array}$ & $\begin{array}{l}\text { About } 50-75 \text { per } \\
\text { cent of input cost }\end{array}$ & $\begin{array}{l}\text { About } 50 \text { per cent } \\
\text { of input cost }\end{array}$ & $\begin{array}{l}\text { About } 50 \text { per cent } \\
\text { of input cost }\end{array}$ & $\begin{array}{l}\text { About } 40 \text { per } \\
\text { cent of input cost }\end{array}$ \\
\hline Exit strategy & Not explicit & $\begin{array}{l}\text { Scaling-down as } \\
\text { the years go by }\end{array}$ & $\begin{array}{l}\text { No - one-year } \\
\text { programme }\end{array}$ & $\begin{array}{l}\text { Three-year exit } \\
\text { plan }\end{array}$ & No \\
\hline $\begin{array}{l}\text { Monitoring and } \\
\text { evaluation system }\end{array}$ & $\begin{array}{l}\text { Yes - numerous } \\
\text { evaluation studies } \\
\text { implemented } \\
\text { (SOAS et al. 2008; } \\
\text { Dorward et al. } \\
\text { 2010) }\end{array}$ & Yes & Not reported & $\begin{array}{l}\text { Yes - conducted } \\
\text { impact evaluation } \\
\text { (Patel 2011; } \\
\text { URT 2014) }\end{array}$ & Not reported \\
\hline $\begin{array}{l}\text { Private sector } \\
\text { development }\end{array}$ & $\begin{array}{l}\text { Yes, but limited; } \\
\text { the private } \\
\text { sector has been } \\
\text { involved in parallel } \\
\text { with parastatal } \\
\text { distribution and } \\
\text { retailing (Chirwa } \\
\text { and Dorward } \\
\text { 2013) }\end{array}$ & $\begin{array}{l}\text { Yes, but limited to } \\
\text { a few contracted } \\
\text { retailers. Concerns } \\
\text { were raised that } \\
\text { the programme } \\
\text { discouraged private } \\
\text { participation } \\
\text { (Mason et al. 2013) }\end{array}$ & $\begin{array}{l}\text { Yes, but limited to } \\
\text { big input supplier } \\
\text { companies, } \\
\text { which reduced } \\
\text { competition and } \\
\text { sales by smaller } \\
\text { retailers (Benin et al. } \\
\text { 2013; Chirwa and } \\
\text { Dorward 2013) }\end{array}$ & $\begin{array}{l}\text { Yes. In some cases } \\
\text { small agro-dealers } \\
\text { could not deliver } \\
\text { the inputs, and big } \\
\text { retailers tended } \\
\text { to be assigned for } \\
\text { delivery by district } \\
\text { government }\end{array}$ & $\begin{array}{l}\text { Yes (Liverpool- } \\
\text { Tasie and } \\
\text { Takeshima 2013) }\end{array}$ \\
\hline
\end{tabular}

Dorward 2013; Jayne and Rashid 2013). ${ }^{3}$ In addition, the use of vouchers emerged as a mechanism for simultaneously targeting subsidies and promoting the private sector. The overview of several features of these programmes in the five SSA countries under study is given in Table 1.

Most of these programmes used decentralised targeting, through traditional authorities, local key stakeholders, voucher committees, or farmer cooperatives. Use of local stakeholders' knowledge during targeting reduces administrative cost, and is common in various antipoverty programmes (Grosh et al. 2008). In the case of Tanzania, voucher committees were established from national to village levels (World Bank 2009). The national level decides the rules and regulations of the programme and evaluates it. This multisectoral arrangement encompasses the government, private sector and farmers' groups. The regional and district committees decide voucher allocation to the lower levels and monitors the programme implementation. The village-level committees select the beneficiary and monitor whether they use inputs.

Though targeting methods varied, all the programmes studied here target small-scale farmers. However, studies suggest that leakage to wealthier 
farmers and elite capture were found in most of the countries (Pan and Christiaensen 2012; Chirwa and Dorward 2013; Jayne and Rashid 2013). In our case study in Tanzania (see Section 3) and in other programmes, decentralised targeting using vouchers based on eligibility criteria - albeit ostensibly more cost-effective and a better way of targeting those in needhas often been subject to elite capture and fraud, and therefore does not work efficiently (Pan and Christiaensen 2012). Liverpool-Tasie (2012a) analysed how the programme in Nigeria targeted farmer groups which would later distribute inputs among smallholder farmers; she suggests that social capital and intragroup dynamics were important in voucher allocation. Femaleheaded households were prioritised in several countries including Malawi, Zambia and Tanzania. However, the evidence in Malawi and the qualitative information in our study in Tanzania show that female-headed households had difficulty obtaining subsidised inputs (Chirwa et al. 2011). An e-voucher system, which avoids manipulation by government officers, politicians, village leaders and agro-dealers by delivering inputs via private input traders directly to the recipients' mobile phones, was piloted in Zambia and is also currently being implemented in Nigeria.

\subsection{Input delivery}

After attempts such as the Starter Pack and the Targeted Input Programme, Malawi launched the first modern Farm Input Subsidy Programme (FISP) across much of the country in 2004/05. This programme aimed to overcome the problems of previous input subsidies: it was targeted at small-scale farmers and achieved wide coverage through the use of vouchers (sometimes known as 'coupons'); and it used the private sector for the procurement and delivery of inputs in order not to distort the input market. This innovative approach, called a 'market-smart' subsidy (Minot and Benson 2009), led to increasing maize production and yields from 2005/06 to 2008/09 (Dorward and Chirwa 2011). This success gave impetus to the pro-subsidy lobby and led to the unanimous commitment of the African Union states to increasing input use through 'market-smart' subsidies to promote food crop yields, mainly of maize (AU 2006). Since the food and input price spikes in 2008, donors such as the World Bank have been supporting these programmes (Benin et al. 2013).

In terms of input procurement and delivery, the Malawi programme used parastatal agencies for input distribution and retailing, but with some participation by private agents in order for mutual trust between government and the private sector to be developed (Chirwa and Dorward 2013). In Tanzania and Nigeria these activities were undertaken by the private sector, which promoted the development of a private input sector through the increased input demand created by subsidies (Liverpool-Tasie and Takeshima 2013; URT 2014), while in Zambia and Ghana input delivery was limited to a few contracted, big input supplier companies, which reduced competition (Mason et al. 2013; Benin et al. 2013). There were problems in input delivery - late input delivery being the inherent problem - due to lack of administrative capacities of the government and/or lack of capacity of the agro-dealers. 


\subsection{Effects and challenges of the 'market-smart' input subsidies}

Studies suggest that most of the programmes brought about increased maize production and maize yields when climatic and economic conditions were favourable. However, a synthesis of recent studies Jayne and Rashid 2013) suggests that the costs of the programme outweighs their benefits. The production gains have been found to be limited due to low fertiliser use efficiency, missing vouchers, and displacement of previously commercial input use (ibid.). The studies reported that the programmes in Malawi, Nigeria, Tanzania and Zambia found increased maize land productivity and output, and in Malawi and Nigeria also increased household income and reduced poverty (Xu et al. 2009b; Yawson et al. 2010; Awotide et al. 2013; URT 2014). Examining the field results of rice-producing farms in Ghana, Wiredu, Zeller and Diagne (2015) suggest that the programme increased land productivity, but reduced labour productivity because more family labour was used in weeding and harvesting.

Meanwhile, most of the programmes were found to be ineffective, due to leakage to wealthier farmers which promoted displacement of commercial input purchase, and late delivery of vouchers and inputs. Using nationally representative panel data in Zambia, Xu et al. (2009a) suggest that the less developed the private sector, the more subsidies tend not to be displacing as they create fertiliser demand. One apparent solution for displacement is e-vouchers, as they deliver subsidised inputs directly to the small-scale farmer recipients' mobile phone, not via government officials, by which Nigeria tripled fertiliser use from 2011 to 2013 per hectare (World Bank 2015).

Studies suggest that input subsidies have had a wider impact on the economy through increased food crop production: this led to a reduction in consumer food prices, to the benefit of poor food consumers; and an increase in rural agricultural wages (Druilhe and Barreiro-Hurle 2012; Chirwa and Dorward 2013; Dorward and Chirwa 2013). However, the benefit has varied with the nature of the subsidies and their context in the market, as well as with the weather. Chirwa and Dorward (2013) suggest that the large scale of the programme relative to the past fertiliser demand brought a reduction in real maize prices, and that it promoted private sector development and agricultural growth. An increase of input use by non-recipient farmers which was probably due to the informational spillover effect was observed in Tanzania (URT 2014). The right benefit- ${ }^{-}$ost ratio (BCR) was keenly debated in the case of Malawi (Jayne et al. 2013, 2015; Dorward and Chirwa 2015). Jayne et al. (2015) suggest that the ratio is negative and that investment in traditional public goods such as agricultural R\&D and extension, or road, rural electrification or other productivity-enhancing investment should be priorities rather than continuous investment in unproductive subsidy programmes (Fan, Gulati and Thorat 2007).

Compared to previous subsidy programmes, all the new programmes found it challenging to improve targeting, transparency, timely delivery 
of voucher distribution, or monitoring and evaluation. Subsidies may also have preferentially benefited areas where the government leadership had a political interest (Banful 2011). The programme in Tanzania found that the late redemption of vouchers by the National Microfinance Bank caused reluctance among the agro-dealers to continue in the subsidy business.

\section{The case of Tanzania - the National Agricultural Input Voucher Scheme (NAIVS)}

This section provides a mixed-methods case study on the Tanzanian voucher scheme (NAIVS) carried out in Ruvuma Region in Tanzania. By using mixed methods we could provide evidence on the impact quantitatively and the qualitative research provided crucial insight into the factors that impacted upon programme performance and outcomes. As Ruvuma normally has a good rainfall, and received a relatively substantial amount of subsidy per farmer - 10 per cent of the subsidy distributed in the country for 3 per cent of the national population - the study could expect to observe some impact. It could thus be relevant as a case study for input subsidies in general in SSA. The study employs: (a) panel data from 340 farm households collected in Ruvuma during the agricultural season previous to the pilot year of the subsidy programme ${ }^{4}$ and again in its third year in order to measure the programme's impact; (b) qualitative information from 130 keyinformant interviews; (c) five farmer-group discussions which were mainly conducted in the region; and (d) secondary data sources.

The intention of the programme was to respond to the food and input crisis in 2008 by ensuring food security, especially that of the poor and vulnerable households facing food and input price hikes. This accords with poverty reduction and economic growth under the overall framework of the National Strategy for Growth and Reduction of Poverty and to prioritising the provision of inputs and services in the Agricultural Sector Development Programme (ASDP). The programme was originally meant to be short term and had an 'exit' strategy.

Our quantitative and qualitative studies found that unclear programme design and various problems in implementation made it unlikely that the programme would yield the expected effects. The panel data regression results do not show any statistically significant impact of voucher receipt on maize yield, income poverty, calorie consumption, household assets or sending children to school among recipient households. Meanwhile, the qualitative data revealed a positive impact on maize yields, food security and poverty reduction. These contradictory results between quantitative and qualitative findings might have been due to the way the panel households were selected, or to the reporting errors in both methods of data collection, such as conformational bias of the interviewees (Copestake and Remnant 2015) and recalling errors (Deaton 1997). While recognising this data limitation, we suggest that the programme did not bring about the expected direct impact on poverty and farmers' livelihoods due to flaws in design and implementation. 
The programme had originally a dualistic design of aiming for national as well as household food security. After the crisis ended, in 2011 the targeted group officially changed from small-scale farmers with less than one hectare under maize or rice cultivation to middle-scale farmers, who cultivate more than one hectare of maize or rice and are able to pay a top-up. However, this reflected the reality revealed since the pilot year. In the first years in practice, better-off farmers became the main users of vouchers because small farmers often did not understand the benefits of input use and anyway could not afford to pay a top-up. It became more difficult for the poor farmers to pay a top-up as the years went by due to the increase in input prices. And the change in the target group also made it difficult to target the same households for three years in order to achieve the stated 'exit' strategy, which was actually hindered from the egalitarian distribution of vouchers by village leaders. This made a thin distribution of vouchers, with 68 per cent of recipient households receiving vouchers for only one or two years.

The implementation of the programme was also flawed due to the frequent late delivery of vouchers, corruption, patron-client relationship, politicised voucher allocation, illegal collusion between leaders and agro-dealers, missing vouchers and resale of vouchers by farmers. We found a large gap between the government data on the number of vouchers distributed in the region and the number of vouchers received as reported by panel households. According to government data, the number of vouchers distributed in the region was nearly three vouchers per farm household during four years of the programme. The practice was very different; a little more than half of panel recipient households were actually issued with vouchers but only in one or two years. The 'missing vouchers' might have been captured by agro-dealers, or by leaders from regional to village level. Vouchers are exchangeable for money, and thus became a source of conflict. When fewer vouchers were distributed, tension became higher among villagers, village leaders, agro-dealers, government officers and lower level politicians. But in the end, politicians, government officials, village leaders and agro-dealers got most of the benefit, while small-scale, poor farmers benefited least from the programme.

An unforeseen problem was the increasing real top-up price which voucher recipients had to pay. This was due to the rise in international market prices, which was also promoted by the power of multinational input supplier companies who provided the inputs to NAIVS. Due to the rise of input market prices, the real value of vouchers to farmers was reduced. With relatively stagnant real maize prices, this made it increasingly difficult for small-scale farmers to pay a top-up.

The challenges of effectiveness and efficiency could be met by making the programme intention clear, strengthening programme design and having a proper implementation plan, while developing sufficient institutional capacity to run the programme well. A mechanism for voucher delivery which is independent of the government administration system needs 
to be established. The implementation plan put in place must seek to prevent the illegal behaviours described above. Effective monitoring and evaluation is necessary for implementation to be accountable.

Part of the subsidy was used as intended, which increased maize production due to the expansion of the total cultivated area, brought about better food security in the region, and raised awareness of the effects of the inputs on maize production. We also found the subsidy had an indirect wider impact on lowering real maize prices and increasing real agricultural wages in the region, which benefited net-food buyer and labour-surplus poor farmers but negatively affected net-food sellers, who were the majority of households in Ruvuma. We also found that the private input sector developed. The programme played an important part in input procurement, and especially in delivery to rural areas. The agro-dealers who worked with NAIVS expressed their intention to carry on after the programme ends, since they know that there is increased demand, and have established links between themselves and farmers. Meanwhile, the increased input demand has been hampered by the increased price of urea in recent years, which has caused a decrease in import quantity.

\section{Successes of and challenges to input subsidy programmes in SSA}

This article has so far provided an overview of the generic features and effects of agricultural subsidies in SSA. This concluding section focuses on challenges to consider for future development of the new 'marketsmart' subsidies now been framed and explored in many SSA countries.

The recent input subsidy programmes were reported to be generally successful in increasing input use, maize production, maize yields and food security, at least under favourable economic and weather conditions, and in promoting private rural input business. A fall in maize prices and an increase in local agricultural wages were also reported in Malawi and our study in Ruvuma Region. These effects benefit net-food buyers and labour-surplus smallholders (Chirwa and Dorward 2013).

However, unclear programme objectives and the various implementation problems prevented most input subsidy programmes from being effective and efficient. A common challenge existed around the programme objectives; whether these were greater national maize production and national food security, or the increased use of productivity-enhancing inputs by poor, small-scale farmers to increase their household food security. In the programmes recently implemented, these two objectives, with different implications for targeting, run alongside each other. With a national food security concern, effectiveness would suggest more emphasis upon increasing the marketed surplus and therefore a preference for targeting larger farmers. However, from an efficiency perspective, marginal productivity might be expected to increase most on farms using lower levels of input use per hectare, which tend to be the small farms. Targeting smaller farmers is clearly also likely to better serve poverty reduction 
and is also more likely to promote more widespread use of inputs in the long term when these smaller farmers are persuaded of the gains from use of improved seed and fertiliser because of their learning through the subsidy programme. Thus, it is quite possible that these different objectives are best served by different targeting strategies. Addressing effectiveness and efficiency concerns meaningfully therefore requires clarity in programme objectives and appropriate design and implementation plans to achieve them.

These results serve to underline the controversial nature of subsidy policies and contemporary debate mirrors historic controversy. One of the historic challenges has been to base policy reform on evidence rather than ideology. Today at last, the evidence to support specific policy agendas is beginning to emerge. The studies suggest that there were frequent reports of elite capture and illicit behaviour. As seen in Ruvuma Region, input subsidy can be a source of tension and conflict in the villages and can increase the gap between middle-scale and poor farmers, where the wealthier and more powerful win most of the benefit. Input subsidies should be targeted more effectively at poor, small-scale farmers, which would also serve social protection needs (Ellis, Devereux and White 2009; FAO 2015).

Despite the negative effects noted, there were positive impacts, such as spillover effects on input use to non-recipients and private sector development in rural areas. The mechanisms to deliver vouchers should be reconsidered in order to reduce the risk of embezzlement of vouchers. Also, the involvement of the private sector for procurement and delivery should be considered depending on the stages of input private sector development. Improved programme monitoring and evaluation is also important, for example to assess the efficacy of promising institutional innovation in delivery such as subsidies provided by e-voucher, piloted in Zambia and implemented in Nigeria.

\section{Notes}

1 The ones in Burkina Faso, Senegal and Mali were universally distributed.

2 There are no scale economies in fertiliser use; nevertheless, an alternative argument is that larger farmers might be better educated or more experienced in fertiliser use and achieve higher marginal productivity. The evidence either way is not wholly conclusive but the evidence on lower fertiliser use per hectare by smaller farmers and the normal assumption of declining returns suggest the marginal productivity argument supports the small farm case.

3 However, among the subsidy programmes studied, only that in Tanzania explicitly mentioned 'exit'.

4 Household Vulnerability Panel conducted by the World Bank and FAO (Christiaensen and Pan 2009). 


\section{References}

AU (2006) Abuja Declaration on Fertilizer for African Green Revolution, Abuja: African Union

Awotide, B.A.; Karimov, A.; Diagne, A. and Nakelse, T. (2013) 'The Impact of Seed Vouchers on Poverty Reduction among Smallholder Rice Farmers in Nigeria', Agricultural Economics 44.6: 647-58

Banful, A.B. (2011) 'Old Problems in the New Solutions? Politically Motivated Allocation of Programme Benefits and the "New" Fertilizer Subsidies', World Development 39.7: 1166-76

Benin, S.; Johnson, M.; Abokyi, E.; Ahorbo, G.; Jimah, K.; Nasser, G.; Owusu, V;; Taabazuing, J. and Tenga, A. (2013) Revisiting Agricultural Input and Farm Support Subsidies in Africa - The Case of Ghana's Mechanization, Fertilizer, Block Farms, and Marketing Programs, Washington DC: International Food Policy Research Institute (IFPRI)

Chirwa, E. and Dorward, A. (2013) Agricultural Input Subsidies: The Recent Malawi Experience, Oxford: Oxford University Press

Chirwa, E.W.; Mvula, P.M.; Dorward, A. and Matita, M. (2011) Gender and Intra-Household Use of Fertilizers in the Malawi Farm Input Subsidy Programme, Brighton: Future Agricultures Consortium

Christiaensen, L. and Pan, L. (2009) Household Vulnerability Panel Survey 3, Washington DC: World Bank

Colclough, Christopher and Manor, James (eds) (1991) States or Markets? Neo-Liberalism and the Development Policy Debate, IDS Development Studies Series, Oxford: Clarendon Press

Copestake, J. and Remnant, F. (2015) 'Assessing Rural Transformations: Piloting a Qualitative Impact Protocol in Malawi and Ethiopia', in K. Roelen and L. Camfield (eds), Mixed Methods Research in Poverty and Vulnerability - Sharing Ideas and Learning Lessons, Hampshire: Palgrave Macmillan

Crawford, E.W.; Jayne, T.S. and Kelly, V.A. (2006) Alternative Approaches for Promoting Fertilizer Use in Africa, Agriculture and Rural Development Discussion Paper 22, Washington DC: World Bank

Deaton, A. (1997) The Analysis of Household Surveys, Baltimore MD and London: Johns Hopkins University Press

Dorward, A.R. and Chirwa, E.W. (2015) 'Crowding Out, Diversion, and Benefit/Cost Assessments in Fertilizer Subsidy Programs in Sub Saharan Africa: A Comment on Jayne, T.S., Mather, D., Mason, N., Ricker-Gilbert, J., 2013. How do Fertilizer Subsidy Programs Affect Total Fertilizer Use in Sub-Saharan Africa? Crowding Out, Diversion, and Benefit/Cost Assessments, Agric. Econ. 44(6), 687-703', Agricultural Economics 46.6: 739-44

Dorward, A. and Chirwa, E. (2013) Impacts of the Farm Input Subsidy Programme in Malawi: Informal Rural Economy Modelling, Brighton: Future Agricultures Consortium

Dorward, A. and Chirwa, E. (2011) The Malawi Agricultural Input Subsidy Programme: 2005-6 to 2008-9, http://eprints.soas.ac.uk/9598/1/ Malawi_fertilizer_case_-_Dorward_\%26_Chirwa_Final_R.pdf (accessed January 2016) 
Dorward, A.; Chirwa, E. and Slater, R. (2010) Evaluation of the 2008/9 Agricultural Input Subsidy Programme, Malawi: Report on Programme Impact, London: SOAS, University of London

Dorward, A. and Kydd, J. (2005) 'Starter Pack in Rural Development Strategies', in S. Levy (ed.), Starter Packs: A Strategy to Fight Hunger in Developing Countries?, Reading: CABI International

Druilhe, Z. and Barreiro-Hurle, J. (2012) Fertilizer Subsidies in Sub-Saharan Africa, ESA Working Paper 12-04, Rome: Food and Agriculture Organization (FAO)

Ellis, F.; Devereux, S. and White, P. (2009) Social Protection in Africa, Cheltenham: Edward Elgar Publishing Ltd

Fan, S.; Gulati, A. and Thorat, S. (2007) Investment, Subsidies and ProPoor Growth in Rural India, Discussion Paper 00716, Washington DC: International Food Policy Research Institute (IFPRI)

FAO (2015) 'The State of Food and Agriculture 2015', Social Protection and Agriculture: Breaking the Cycle of Rural Poverty, Rome: Food and Agriculture Organization (FAO)

Grosh, M.; Del Ninno, C.; Tesluiuc, E. and Ouerghi, A. (2008) For Protection and Promotion: The Design and Implementation of Effective Safety Nets, Washington DC: World Bank

Jayne, T.S. and Rashid, S. (2013) 'Input Subsidy Programs in Sub Saharan Africa: A Synthesis of Recent Evidence', Agricultural Economics 44.6: 547-62

Jayne, T.S.; Mather, D.; Mason, N. and Ricker-Gilbert, J. (2013) 'How do Fertilizer Subsidy Programs Affect Total Fertilizer Use in Sub-Saharan Africa? Crowding Out, Diversion, and Benefit/Cost Assessments', Agricultural Economics 44.6: 687-703

Jayne, T.S.; Mather, D.; Mason, N.M.; Ricker-Gilbert, J. and Crawford, E.W. (2015) 'Rejoinder to the Comment by Andrew Dorward and Ephraim Chirwa on Jayne, T. S., D. Mather, N. Mason, and J. Ricker-Gilbert. 2013. How do Fertilizer Subsidy Programs Affect Total Fertilizer Use in Sub-Saharan Africa? Crowding Out, Diversion, and Benefit/Cost Assessments. Agric. Econ. 44(6), 687-703', Agricultural Economics 46.6: 745-55

Lipton, Michael (1991) Market Relaxation and Agricultural Development', in G. Colclough and J. Manor (eds), States or Markets?, Oxford: Oxford University Press

Lipton, Michael (with Longhurst, Richard) (1989) New Seeds and Poor People, London and Baltimore MD: Unwin Hyman and Johns Hopkins University Press

Lipton, Michael (1977) Why Poor People Stay Poor: Urban Bias and World Development, London and Cambridge MA: Temple Smith and Harvard University Press

Lipton, Michael (1968) 'The Theory of the Optimising Peasant', Fournal of Development Studies 4.3: 327-51

Liverpool-Tasie, L.S. (2012a) Farmer Groups, Input Access and Intragroup Dynamics: A Case Study of Targeted Subsidies in Nigeria, Washington DC: International Food Policy Research Institute (IFPRI) 
Liverpool-Tasie, L.S. (2012b) Targeted Subsidies and Private Market Participation, Washington DC: International Food Policy Research Institute (IFPRI) Liverpool-Tasie, L.S.O. and Takeshima, H. (2013) 'Input Promotion Within a Complex Subsector: Fertilizer in Nigeria', Agricultural Economics 44: 581-94

Mason, N.M.; Jayne, T.S. and Mofya-Muhuka, R. (2013) 'Zambia's Input Subsidy Programs', Agricultural Economics 44.6: 613-28

Maxwell, S. (2001) 'Agricultural Issues in Food Security', in S. Devereux and S. Maxwell (eds), Food Security in Sub-Saharan Africa, London: ITDG Publishing

Minot, N. and Benson, T. (2009) 'Fertilizer Subsidies in Africa', IFPRI Issue Brief 60, Washington DC: International Food Policy Research Institute (IFPRI)

Morris, M.; Valerie, A.K.; Kopicki, R.J. and Byerlee, D.R. (2007) Fertilizer Use in African Agriculture: Lessons Learned and Good Practice Guidelines, Washington DC: World Bank

Pan, L. and Christiaensen, L. (2012) 'Who is Vouching for the Input Voucher?: Decentralized Targeting and Elite Capture in Tanzania', World Development 40.9: 1619-33

Patel, S. (2011) Tanzania National Agricultural Input Voucher Scheme Impact Evaluation: Baseline Report, Washington DC: World Bank

Potter, H. (2005) 'The Players and the Policy Issues', in S. Levy (ed.), Starter Packs: A Strategy to Fight Hunger in Developing Countries? Lessons from the Malawi Experience 1998-2003, Reading: CABI Publishing

Poulton, C.; Dorward, A. and Kydd, J. (2009) 'The Future of Small Farms: New Direction for Services, Institutions, and Intermediation', World Development 38.10: 1413-28

Ricker-Gilbert, J. and Jayne, T.S. (2012) 'Do Fertilizer Subsidies Boost Staple Crop Production and Reduce Poverty Across the Smallholders in Africa? Quantile Regression from Malawi', International Association of Agricultural Economists Terrenial Conference, Foz do Iguaçu, 18-24 August

Ricker-Gilbert, J.; Jayne, T. and Shively, G. (2013) 'Addressing the "Wicked Problem" of the Input Subsidy Programs in Africa', Applied Agricultural Economic Perspectives and Policy 35.2: 322-40

SOAS, Wadonda Consult and Michigan State University (2008) 'Evaluation of the 2006/7 Agricultural Input Subsidy Programme, Malawi, Final Report', unpublished

URT (United Republic of Tanzania ) (2014) Tanzania Public Expenditure Review: National Agricultural Input Voucher Scheme (NAIVS), Dar es Salaam: Ministry of Agriculture, Food and Cooperatives (MAFC)

Wiredu, A.N.; Zeller, M. and Diagne, A. (2015) Impact of Fertilizer Subsidy on Land and Labor Productivity of Rice-Producing Households in Northern Ghana, Oxford: Centre for the Study of African Economies

World Bank (2015) World Bank Develoment Indicators, http://data.worldbank. org/products/wdi (accessed 26 February 2016)

World Bank (2009) Accelerated Food Security Program of the United Republic of Tanzania under the Global Food Crisis Response Program, Washington DC: World Bank 
World Bank (2007) World Development Report 2008: Agriculture for Development, Washington, DC: International Bank for Reconstruction and Development/World Bank

Xu, Z.; Burke, W.J.; Jayne, T.S. and Govereh, J. (2009a) 'Do Input Subsidy Programs Crowd In or Crowd Out Commercial Market Development? Modeling Fertilizer Use Decisions in a Two-Channel Marketing System', Agricultural Economics 40.1: 79-94

Xu, Z.; Guan, Z.; Jayne, T.S. and Black, R. (2009b) 'Factors Influencing the Profitability of Fertilizer Use on Maize in Zambia', Agricultural Economics 40.4: 437-46

Yawson, D.O.; Ahmah, F.A.; Afrifa, E.K.A. and Dadzie, S.K.N. (2010) 'Ghana's Fertilizer Subsidy Policy: Early Field Lessons from Farmers in the Central Region', Journal of Sustainable Development in Africa 12.3: 191-203 


\title{
Adapting to Climate Change: Transforming Development?
}

\author{
Rachel Godfrey-Wood and Lars Otto Naess
}

\begin{abstract}
This article examines the implications of the growing discussion around transformation and adaptation for development policy and practice. While there is increasing agreement that incremental approaches are insufficient to tackle climate change, and that deeper transformative change is also necessary, the ways in which transformation is understood vary significantly, and hence how it is to be operationalised remains unclear. Tracing the emergence of transformation in adaptation debates, and linking them to the intellectual roots of the idea of transformation, we interrogate different approaches that exist towards transformation in terms of moving beyond dominant neoliberal development trajectories. The article discusses some of the conceptual and practical challenges in bringing about transformational change in international development, concluding with some suggestions for the way forward in operationalising transformation for development in line with long-term climate change adaptation goals.
\end{abstract}

\section{Introduction}

There is a growing realisation that the threat of climate change, primarily to the world's poor, asks profound questions of existing paradigms of development, both in causing and perpetuating vulnerability to climate-related risks, and their suitability to address future climate change (Brooks, Grist and Brown 2009; Manuel-Navarrete 2010). This has led to a proliferation of analytical approaches emphasising the need to radically change existing structures in order to successfully adapt to climate change, most notably represented by the growing literature on transformation and adaptation to climate change (O'Brien 2011; Ribot 2011; Pelling, O’Brien and Matyas 2015; Tschakert et al. 2013; Bahadur and Tanner 2014). Transformation has emerged in climate change debates as a response to concerns that the key terms that frame policy debates, adaptation, and increasingly, resilience, put the focus solely on incremental adjustments to an increasingly unstable climate, overlooking both the relational causes of vulnerability and the need for systemic and structural changes to address vulnerability to climate change. The increasing prominence of transformation in mainstream adaptation literature is reflected in the latest Intergovernmental Panel on Climate 
Change (IPCG) report, which distinguishes between incremental and transformational adaptation, and defining the latter as 'adaptation that changes the fundamental attributes of a system in response to climate and its effects' (Agard et al. 2014: 1758).

However, there is as yet little evidence or clarity on what transformation is. This article examines the implications of the discussion around transformation in adaptation for development policy and practice. The motivation is that while there is increasing agreement that transformation is needed to successfully adapt to climate change, the way in which transformation is understood varies significantly, and hence how it is to be operationalised remains unclear. While transformation may be understood as an analytical concept which has no inherent superiority over more incremental forms of adaptation or resilience building (see Béné et al. 2014; Matyas and Pelling 2014), it can also be used in a normative sense as part of a necessarily radical political project of deep-seated institutional change (Tschakert et al. 2013; Feola 2015). In this article we are primarily concerned with exploring the implications of transformation in the second sense, borne out of the need to challenge unequal systems of power and distribution of wealth.

In doing so, we will argue, along with other authors (e.g. Tschakert et al. 2013; Feola 2015), that the concept is necessary, and also that it needs to be accompanied by a clear definition which does not shy away from its political message. For the purposes of this article, we will understand transformation as processes which fundamentally redefine social, political or economic structures. As we will see, these should not always be assumed to be positive, and it can be argued that many past transformations have served to accentuate inequalities or generate new ones.

The article begins with tracing the emergence of transformation in adaptation debates, and the contribution of the Institute of Development Studies (IDS) to these debates (Section 2). We then link these debates to the intellectual roots of the idea of transformation, and chart some of the different approaches that exist towards transformation in terms of moving beyond dominant neoliberal - and arguably unsustainable - development trajectories (Section 3). Following this, we discuss some of the conceptual and practical challenges in bringing about transformational change in international development (Section 4). Finally, we conclude with some suggestions for the way forward in operationalising transformation for development in line with long-term climate change adaptation goals.

\section{Adaptation and the emergence of transformation}

While adaptation was part of the goals of the United Nations Framework Convention on Climate Change (UNFCCG) from the outset in 1992, the global climate change research and policy debate focused almost exclusively on mitigation for most of the 1990s. At this stage, climate change policy was very much in the realm of 'environmentalist' organisations and researchers, and few if any development organisations had considered climate change in their thinking and projects. This 
began to change with IPCC's Second Assessment report in 1995, which put increasing weight on adaptation, but more significantly with the 2001 Third Assessment report, which for the first time devoted a separate chapter to adaptation, sustainable development and equity (Smit et al. 2001). While some development agencies (government as well as non-governmental organisations (NGOs)) started emphasising the importance of climate change in the late 1990s (Burton and van Aalst 1999), adaptation only gained widespread focus in the early 2000s (Klein 2001; AfDB et al. 2003; Eriksen and Naess 2003).

Adaptation is not a new idea, however. As a term it has its origin in evolutionary biology (Smit and Wandel 2006), and emerged in social sciences in the hazards literature (e.g. Burton, Kates and White 1978). It became a severely contested concept, particularly from political ecology scholars, who argued that adaptation theory failed to address power relations and structural inequalities as causes of vulnerability (Watts 1983). Following this, adaptation became a term 'not to be mentioned in polite society' (Burton 1994), until it was revived through IPCC and UNFCGC in the late 1980s and early 1990s.

Until the early to mid-2000s, adaptation to climate change was overwhelmingly considered as a technical and managerial challenge of responding and adjusting to the impacts of climate change. Structural and social causes of vulnerability were occasionally mentioned, but often downplayed and framed in vague terminology such as 'political and institutional inefficiencies' (Bassett and Fogelman 2013; Ribot 2014). Watts (2015) argues that the current discussion of adaptation recycles much of what was wrong about the earlier theories of adaptation to environmental hazards, namely that they depended on biological metaphors that obscure unequal power relations and emphasise proximate outcomes rather than structural processes. As Ribot $(2011,2014)$ argues, through its focus on proximate causes and asking 'who' is vulnerable rather than 'why', adaptation runs the risk of taking attention away from the social and political causes of vulnerability, focusing on the impacts of climate change but not on the inequalities that generate vulnerability. This facilitates climate change assessments which exclude root-cause analysis, leading to ahistorical and apolitical accounts of adaptation (Ribot 2014).

Arguably, transformation has emerged in response to these concerns, as a number of scholars have over recent years advanced the concept of 'transformation' (sometimes referred to as 'transformative adaptation') as a means of highlighting the need for systemic change to the social systems generating vulnerability (Ribot 2011; O'Brien 2011; Pelling 2010), and to highlight the political nature of adaptation (e.g. Tschakert et al. 2013; Eriksen, Nightingale and Eakin 2015). In doing so, the development of transformation has adopted the earlier political ecology critique of the hazards literature, namely that it overlooks the fact that vulnerability is socially produced through unequal relations of power (e.g. O'Keefe, Westgate and Wisner 1976; Watts 1983; Taylor 2015). 
IDS has made several key contributions in this area, both conceptually in understanding, challenging and developing the concepts of resilience and transformation and their interrelations (e.g. Bahadur, Ibrahim and Tanner 2010; Bahadur and Tanner 2012, 2014; Tanner and Bahadur 2013; Béné et al. 2012, 2014). Furthermore, it has provided studies which have shaped future debates on transformation, for example by highlighting the importance of power relations in processes of change (e.g. Gaventa 2006), and the perils of top-down approaches to conservation (Leach and Mearns 1996). Over recent years, the University of Sussex-IDS STEPS Centre has played a central role investigating alternative pathways to transformation (e.g. Leach, Scoones and Stirling 2010; Smith 2014; Smith and Ely 2015).

The fact that transformation has moved into the mainstream of the adaptation research and policy debate over the past two to three years could in some ways be interpreted as a tilt back in the favour of political ecology-influenced interpretations of structural vulnerability and the need for radical change. However, as Feola (2015) argues, 'transformation' is often used as a vague metaphor to convey the idea of a 'radical' but poorly defined change of a given system. Its uses vary from psycho-social processes whereby humans commit to changing their behaviour, new technological or social innovations, or the use of participatory methods during NGO project interventions (Tanner and Bahadur 2013). While all these can be seen as important changes, it is unclear whether they reflect fundamentally different approaches, or whether they represent serious structural change, creating the possibility that the term could be used in rather non-transformative ways. While as noted above the IPCC has started using the term 'transformative adaptation', this has not significantly altered its conceptual approach to adaptation overall, which continues to be viewed as adjustments to climate stimuli (Bassett and Fogelman 2013; Watts 2015). As with resilience, one might argue that transformation allows researchers of different disciplines to find common ground, but without necessarily acknowledging the different ways in which it is understood. In turn, this creates significant challenges for how to operationalise transformation as a normative goal to support adaptation and development goals.

\section{Radical transformations to address climate change}

The argument about the need for radical transformations to tackle climate change begins from the starting point that the current status quo is itself an outcome of a series of historical transformations. Polanyi (2001: 138) used the term 'transformation' to refer to a project to drive towards a disembedded market which would be unregulated by the rest of society. Although this project was ultimately utopian due to the impossibility of a genuinely disembedded market, it nonetheless profoundly destabilised the existing pre-industrial society, generating counter-movements and pushes towards social protection by actors 'affected by the deleterious action of the market'. Colonialism accentuated this by bringing transformations to the developing world, in the process undermining existing social orders and generating new 
forms of vulnerability, in many cases causing devastating famines as documented by Watts (1983) and Davis (2002), among others. This is not to deny the gains made through development. Rather, it points to the fact that it is the very success of the capitalist transformation which has generated the social and ecological challenges we face today, improving material standards tremendously but at the same time locking human development into unsustainable consumption patterns (Schmitz and Scoones 2015). Concurrently, it is also clear that capitalism in its current neoliberal form has created huge inequalities of wealth. Stiglitz (2012) shows how this enables global elites to exert decisive influence over political systems, in turn undermining democracy and destabilising the global economy through rent-seeking practices. While recent decades have seen important improvements in living standards, these have not been caused by financialised globalisation per se, but rather by longer-term processes of scientific and technological change, suggesting there is no trade-off between higher living standards and equity (Smith 2016).

All of this points towards the inadequacy of the existing paradigm to address climate change in an equitable way, an idea popularised recently by Klein (2014). The author argues that key neoliberal policies such as privatisation, corporate deregulation and low taxes all reduce the capacity of the state to bring about the necessary transformations in society and rather subordinate it to the interests of the private sector. Similarly, Sterling (2014) argues that unless unequal power relations are challenged, and alternative pathways are identified, there is a real danger that the pressure for 'transformation' will lead to approaches that further concentrate power, for example through nuclear energy, carbon trading and geoengineering. This raises the question of which types of transformations will be necessary if human development is to generate sustainable and equitable wellbeing for the world's inhabitants. Schmitz and Scoones (2015) identify four narratives for transformation: marketled, technology-led, state-led and citizen-led. Market-led approaches, exemplified by carbon trading, are closely aligned with the existing status quo, and are more likely to accentuate existing injustices than bring about the types of changes that are required (e.g. Lohmann 2012). Academics and activists have also increasingly debated the possibility that land and resources could be appropriated for environmental ends, in a phenomenon dubbed as 'green grabbing' (Fairhead, Leach and Scoones 2012). This argument is rooted in the understanding that conventional approaches to environmental conservation have historically accentuated the marginalisation of particular groups and closed down democratic spaces in the name of environmental sustainability (e.g. Brockington 2002; Hutton, Adams and Murombedzi 2005; Ribot 2006; Li 2007). The danger therefore is not simply that market-led 'solutions' could prove ineffective, but that they could generate new risks and distract from the radical transformations necessary to tackle climate change.

Klein (2014), in the time-honoured tradition of many radical environmentalists, places much of her faith in social movements, in what 
might be termed a 'citizen-led' narrative. She argues that environmentalist movements, particularly ones led by indigenous people, are leading the way by opposing fossil-fuel extraction, thus raising environmental awareness and forcing the rest of society into changing course. This strategy, however, relies heavily on a rather simplistic and romanticised view of indigenous people as the final moral reserves of humanity (see Ramos 1998 for a critique of the approach of environmentalists towards indigenous people), and fails to seriously address the need for massive state-led investments in a new energy system in order for the world to transition away from fossil fuels (Hoexter 2014). A more sophisticated approach to citizen-led transformation is to combine it with a technology-led approach, emphasising the potential of new technologies to decentralise power and promote green technology at the same time (Fressoli et al. 2014; Smith and Ely 2015). A particularly ambitious version of a technology-plus-citizen approach to transformation argues that new technology is bringing the cost of reproducing information to zero, thus undermining the pricing mechanisms inherent to capitalism, and facilitating new forms of decentralised, citizen-led initiatives which can progressively move towards a 'postcapitalist' society (Mason 2015). A paradigmatic example of a citizen-plus-technology-led initiative is that of the Lucas Plan of the 1970s in the UK, which was devised by workers facing the threat of job losses, and who proposed redirecting public funding from arms production to socially useful production including renewable energy (Smith 2014). Crucially, such initiatives are likely to require nurturing from the state if they are to be both transformative and also operate at scale. ${ }^{1}$

State-led narratives emphasise the possibility of coordinated public action to undertake environmental planning, based on the compelling evidence that technological transformations have historically been driven by the state (Mazzucato 2013). If combined with serious efforts to redistribute wealth and power, such an approach could address both climate change and inequality simultaneously. However, the potential of actors to enact the required progressive change through the state raises age-old questions about the difficulty of reorienting state institutions which have been established and fine-tuned to achieve fundamentally different objectives, and which are manned by actors (i.e. the civil service) who are hostile to transformative change (Miliband 2009). Even well-intentioned governments may be too structurally dependent on the interests of capital and too electorally dependent on the support of the groups who either already have, or aspire to, high consumption and fossil fuel-dependent lifestyles (Sayer 2009). Moreover, while there is clearly a growing global constituency in favour of breaking with the status quo, be that in the form of neoliberal austerity in Western Europe or authoritarianism in the Middle East, these demands are occurring at the same time that options for political and economic alternatives appear more restricted than ever. In 2015 even the Syriza-led Greek government's demand for a shift towards greater public investment and social safety nets was deemed to be unacceptable by Europe's elite, who exercised their control over the country's liquidity to force them into implementing the very policies they had previously criticised. Meanwhile, the Arab Spring has been largely overwhelmed by a combination of reactionary Islamist movements and authoritarianism. These events 
demonstrate that regardless of the approach taken towards transformation, unequal power relations can prevent any transformative change, regardless of the undoubted strengths of the movements concerned.

\section{Challenges for radical transformation of development to support adaptation}

The difficulties of achieving radical transformation through changes of governments and social movements are mirrored, albeit on a smaller scale, by the problems facing researchers and NGOs interested in transformation in the development sector. The need for radical transformation to tackle climate change and its impacts in developed countries is mirrored by researchers working on climate change in developing countries, who agree that the issue demands a radical break with existing models of development (e.g. Brooks et al. 2009). There is a growing literature emphasising the roles of inequality and power relations in generating and perpetuating vulnerability to climate change (e.g. Eriksen and O'Brien 2007; Pelling 2010; Eriksen et al. 2015; Brown 2015). This realisation is linked to a broader scepticism of adaptation which depends solely on technological interventions, for failing to take into account the social relations and structures which drive inequality, and which in turn could be subject to elite capture and increase vulnerability for the poorest. A notable historical example of this is the Bangladesh Flood Action Plan, critiqued by Blaikie et al. (1994) as being top-down and ultimately benefiting non-poor groups disproportionately, and making the poorest more vulnerable. More recently, political ecology scholars (e.g. Peet, Robbins and Watts 2011; Taylor 2013) call for close attention to the precise mechanisms of 'adverse inclusion' which link the security of some to the vulnerability of others. In a case study of Andhra Pradesh, Taylor (2013) shows how, in the context of agrarian liberalisation, exploitative debt and credit relationships combined with the over-exploitation of groundwater reserves harmed human security, and ultimately manifested in a spate of farmer suicides. Addressing this seriously, he emphasises, requires a fundamental challenge to the balance of power in the region, which would require implementing not only the existing social protection scheme (the MGNREGA), but also a range of policy changes including redistributive land reform, protection of agriculture from imports, and guaranteed prices for crops.

However, in spite of the fact that there is a growing number of researchers and development professionals who agree on the need for radical transformation to tackle climate change, this understanding has not yet translated into change on the ground in adaptation projects and programmes. In practice, most adaptation projects preserve rather than challenge existing structures and relationships. This is unlikely to be the result of an intellectual failure among the climate change and development community, but rather more deep-rooted structures in how adaptation is conceived and carried out. Many government agencies or development organisations invested with climate policy will often have a stake in maintaining the status quo rather than changing it (Pelling et al. 2015). Radical and political 'policy recommendations' that researchers 
might make are simply not what donors want to hear, akin to what Ferguson (1990) reports as the response to his recommendation of boycotting the apartheid regime in South Africa to help reduce poverty in Lesotho. This draws attention to the political agendas of the research process itself (Crane 2014). In the field, NGOs, development and government agencies are under pressure to come up with 'practical' policy recommendations and solutions which, as Taylor acknowledges, tend to become confused once the deeper structural issues are analysed (Taylor 2013). Moreover, even in the cases where development professionals and researchers come to the conclusion that 'radical' solutions are necessary, they are often in a poor position to advocate for these, particularly when operating in a different political context. Even with radical intentions, there are tactical questions about how much can be achieved if indeed the poor are structurally dependent on elites, requiring a more nuanced approach (e.g. Wong 2010), and legitimate ethical questions about how far foreign or foreign-backed organisations should go in attempting to 'transform' power relations in developing countries.

Many researchers advocating more transformative approaches to adaptation call for the inclusion of the voices of the poorest and most vulnerable actors (e.g. Eriksen and Marin 2014). However, ensuring that vulnerable people have a 'voice' cannot necessarily be equated with transformative outcomes, and may have little effect unless they are accompanied by changes in structures for representation and power. External actors may lack the necessary understanding of existing patterns of resource use or access, obscuring the reality that most people's livelihoods span across different places and scales and leading to poorly thought-out attempts to form local institutions (Leach et al. 2010; Scoones 2015).

Even when local institutions are responsive to local concerns, it does not necessarily mean that there will be transformative outcomes, or transformative outcomes that benefit the poorest and most vulnerable groups. Pelling et al. (2015: 12) argue that in participatory methodologies 'there is a tendency for communities to prioritize immediate risks (such as road traffic accidents) and discount the importance of future risks'. Ultimately, such approaches may lead to solutions which delay transformation and increase long-term risk (Matyas and Pelling 2014). Meanwhile, there is by now significant evidence of elite capture of participatory projects by particular stakeholders, while the most vulnerable groups are often excluded and cannot exercise the same levels of influence, challenging the assumption that participatory approaches are necessarily transformative (Cleaver 2007; Mansuri and Rao 2012).

\section{Conclusion}

In this article we have interrogated the term 'transformation' in relation to adaptation to climate change, and its implications for development policy and practice. The article traced the origins of current discussions concerning the issue of transformation, charting their roots back to the political ecology critique of the 'hazard' paradigm in the late 1970s. The resurgence of this in the critique of the mainstream approach 
to climate change adaptation, until recently overlooking structural inequalities and power relations driving vulnerability, is undoubtedly necessary, particularly during a period of history when there is growing questioning of the dominant paradigm of neoliberal capitalism.

Nevertheless, we see two key challenges to take this forward and ensure that transformation is useful in supporting adaptation to climate change among the poorest and most vulnerable. The first is the need to demand a minimum degree of ideological clarity about what transformation means. This means going beyond references to 'systemic change', and to be more explicit in what is required in order to support its aims, notably bringing about redistribution of power and wealth. Second, as proponents of what we term radical transformation, there is a need to go beyond the critiquing of mainstream approaches to adaptation, to better understand how transformation happens, for whose benefit. Both these are obviously challenging given that, as we have argued, there are fundamental limits to what can be achieved from within the development sector.

However, there are different approaches which could lead the way to better understanding transformational adaptation to climate change, many of which have roots in existing development practice. One of these is described by Ribot (2014), who calls for, among other things, a redirection towards emancipatory approaches addressing rights and representation of citizens to address the root causes of vulnerability, focusing on the poor and climate-vulnerable and their organisations. Examples here may be groups of smallholders and slum-dwellers, or trade unions, a sector often overlooked by development organisations but who are unquestionably crucial actors in any strategy aiming to bring about fairer distributions of wealth and power. For the reasons outlined in the previous section, this is not a 'silver bullet' for radical change, but could help in the building up of representative organisations and ownership with the potential to affect long-term change, while avoiding the pitfalls of external dictation of policies to support the poor.

\section{Notes}

1 Indeed the Lucas Plan itself benefited from the support shown to it briefly by the Ministry of Industry in 1974-5 under the Labour government.

2 Full list of authors: African Development Bank (AfDB); Asian Development Bank (ADB); Department for International Development (DFID); Dutch Ministry of Foreign Affairs (DGIS); European Commission (EC); Federal Ministry for Economic Cooperation and Development (BMZ); Organisation for Economic Co-operation and Development (OECD); United Nations Development Programme (UNDP); United Nations Environment Programme (UNEP) and World Bank.

3 Full list of authors: Agard, J.; Schipper, E.L.F.; Birkmann, J.; Campos, M.; Dubeux, C.; Nojiri, Y.; Olsson, L.; Osman-Elasha, B.; Pelling, M.; Prather, M.J.; Rivera-Ferre, M.G.; Ruppel, O.C.; Sallenger, A.; Smith, K.R.; St. Clair, A.L.; Mach, K.J.; Mastrandrea, M.D and Eren Bilir, T. 


\section{References}

AfDB (African Development Bank) et al. ${ }^{2}$ (2003) Poverty and Climate Change: Reducing the Vulnerability of the Poor through Adaptation, Nairobi: United Nations Environment Programme (UNEP)

Agard, J. et al. ${ }^{3}$ (2014) Glossary, IPCC Fifth Assessment Report, Geneva: Intergovernmental Panel on Climate Change (IPCG)

Bahadur, A.V. and Tanner, T. (2014) 'Transformational Resilience Thinking: Putting People, Power and Politics at the Heart of Urban Climate Resilience', Urbanization and Environment 26.1: 200-14

Bahadur, A.V. and Tanner, T. (2012) Transformation: Theory and Practice in Climate Change and Development, Brighton: IDS, www.ids.ac.uk/ publication/transformation-theory-and-practice-in-climate-changeand-development (accessed 29 February 2016)

Bahadur, A.V.; Ibrahim, M. and Tanner, T. (2010) The Resilience Renaissance? Unpacking of Resilience for Tackling Climate Change and Disasters, Strengthening Climate Resilience (SCR) Discussion Paper 1, Brighton: IDS, http://community.eldis.org/.59e0d267/resilience-renaissance.pdf (accessed 29 February 2016)

Bassett, T.J. and Fogelman, C. (2013) 'Déjà Vu or Something New? The Adaptation Concept in the Climate Change Literature', Geoforum 48: 42-53

Béné, C.; Godfrey-Wood, R.; Newsham, A. and Davies, M. (2012) Resilience: New Utopia or New Tyranny? Reflection about the Potential and Limits of the Concept of Resilience in Relation to Vulnerability Reduction Programmes, IDS Working Paper 405, Brighton: IDS, www.ids.ac.uk/ files/dmfile/Wp405.pdf (accessed 29 February 2016)

Béné, G.; Newsham, A.; Davies, M.; Ulrichs, M. and Godfrey-Wood, R. (2014) 'Review Article: Resilience, Poverty, and Development', fournal of International Development 26.5: 598-623

Blaikie, P.M.; Cannon, T.; Davis, I. and Wisner, B. (1994) At Risk: Natural Hazards, People's Vulnerability and Disasters, London and New York NY: Routledge

Brockington, D. (2002) Fortress Conservation: The Preservation of the Mkomazi Game Reserve, Oxford: James Currey

Brooks, N.; Grist, N. and Brown, K. (2009) 'Development Futures in the Context of Climate Change: Challenging the Present and Learning from the Past', Development Policy Review 27.6: 741-65

Brown, K. (2015) Resilience, Development and Global Change, Abingdon: Routledge

Burton, I. (1994) 'Deconstructing Adaptation... and Reconstructing', Delta 5.1: 14-15

Burton, I. and van Aalst, M.K. (1999) Come Hell or High Water: Integrating Climate Change Vulnerability and Adaptation into Bank Work, World Bank Environment Department Papers 72, Washington DC: World Bank

Burton, I.; Kates, R.W. and White, G.F. (1978) The Environment as Hazard, New York NY: Oxford University Press

Cleaver, F. (2007) 'Understanding Agency in Collective Action', fournal of Human Development 8.2: 222-44 
Crane, T.A. (2014) 'Bringing Science and Technology Studies into Agricultural Anthropology: Technology Development as Cultural Encounter between Farmers and Researchers', Culture, Agriculture, Food and Environment 36.1: 45-55

Davis, M. (2002) Late Victorian Holocausts: El Niňo Famines and the Making of the Third World, London: Verso

Eriksen, S.H. and Marin, A. (2014) 'Sustainable Adaptation under Adverse Development? Lessons from Ethiopia', in T.H. Inderberg, S. Eriksen, K. O'Brien and L. Sygna (eds), Climate Change Adaptation and Development: Transforming Paradigms and Practices, Abingdon: Routledge

Eriksen, S. and Naess, L.O. (2003) Pro-Poor Climate Adaptation: Norwegian Development Cooperation and Climate Change Adaptation: An Assessment of Issues, Strategies and Potential Entry Points, CICERO Report 2003:02, Oslo: Centre for International Climate and Environmental Research (CICERO)

Eriksen, S. and O'Brien, K. (2007) 'Vulnerability, Poverty and the Need for Sustainable Adaptation Measures', Climate Policy 7.4: 337-52

Eriksen, S.H.; Nightingale, A.J. and Eakin, H. (2015) 'Reframing Adaptation: The Political Nature of Climate Change Adaptation', Global Environmental Change 35: 523-33

Fairhead, J.; Leach, M. and Scoones, I. (2012) 'Green Grabbing: A New Appropriation of Nature?', Journal of Peasant Studies 39.2: 285-307

Feola, G. (2015) 'Societal Transformation in Response to Global Environmental Change: A Review of Emerging Concepts', Ambio 44.5: 376-90

Ferguson, J. (1990) The Anti-Politics Machine: Development, Depoliticization and Bureaucratic Power in Lesotho, Minneapolis MN: University of Minnesota Press

Fressoli, M.; Around, E.; Abrol, D.; Smith, A.; Ely, A. and Dias, R. (2014) 'When Grassroots Innovation Movements Encounter Mainstream Institutions: Implications for Models of Inclusive Innovation', Innovation and Development, http://steps-centre.org/wp-content/ uploads/FressoliEtAl-Second-Revised-Paper-rh-MF-x-STEPS.pdf (accessed 31 July 2015)

Gaventa, J. (2006) 'Finding the Spaces for Change: A Power Analysis', IDS Bulletin 37.6: 23-33, http://bulletin.ids.ac.uk/idsbo/article/ view/898 (accessed 8 March 2016)

Hoexter, M. (2014) 'Book Review: Naomi Klein's "Hard-Money" Ideas Undermine Her Laudable Climate Action Goals', New Economics Perspective blog, http://neweconomicperspectives.org/2014/11/ naomi-kleins-hard-money-ideas-undermine-laudable-climate-actiongoals.html (accessed August 2015)

Hutton, J.; Adams, W.M. and Murombedzi, J.C. (2005) 'Back to the Barriers? Changing Narratives in Biodiversity Conservation', Forum for Development Studies 32.2: 341-70

Klein, N. (2014) This Changes Everything: Capitalism vs the Climate, London: Penguin

Klein, R.J.T. (2001) Adaptation to Climate Change in German Official Development Assistance - An Inventory of Activities and Opportunities with 
a Special Focus on Africa, Eschborn: Deutsche Geschellschaft for Technische Zusammenarbeit

Leach, M. and Mearns, R. (eds) (1996) The Lie of the Land: Challenging Received Wisdom on the African Environment, Oxford: James Currey

Leach, M.; Scoones, I. and Stirling, A. (2010) Dynamic Sustainabilities: Technology, Environment, Social Justice, London: Earthscan

Li, T.M. (2007) The Will to Improve: Governmentality, Development, and the Practice of Politics, London: Routledge

Lohmann, L. (2012) 'Financialization, Commodification and Carbon: the Contradictions of Neoliberal Climate Policy', Socialist Register 48: 85-107

Mansuri, G. and Rao, V. (2012) Localizing Development: Does Participation Work?, World Bank Policy Research Report, Washington DC: World Bank

Manuel-Navarrete, D. (2010) 'Power, Realism, and the Ideal of Human Emancipation in a Climate of Change', Climate Change 1: 781-85

Mason, P. (2015) Postcapitalism: A Guide to Our Future, London: Allen Lane

Matyas, D. and Pelling, M. (2014) 'Positioning Resilience for 2015: The Role of Resistance, Incremental Adjustment and Transformation in Disaster Risk Management Policy', Disasters 39.Suppl 1: S1-18

Mazzucato, M. (2013) The Entrepreneurial State: Debunking Public vs Private Sector Myths, London: Anthem Press

Miliband, R. (2009, first published 1969) The State in Capitalist Society, London: Merlin Press

O'Brien, K. (2011) 'Global Environmental Change II: From Adaptation to Deliberate Transformation', Progress in Human Geography: 1-10

O'Keefe, P.; Westgate, K. and Wisner, B. (1976) 'Taking the Naturalness out of Natural Disasters', Nature 260.5552: 566-7

Peet, R.; Robbins, P. and Watts, M.J. (2011) Global Political Ecology, London: Routledge

Pelling, M. (2010) Adaptation to Climate Change: From Resilience to Transformation, London: Routledge

Pelling, M.; O'Brien, K. and Matyas, D. (2015) 'Adaptation and Transformation', Climatic Change 133.1: 113-27

Polanyi, K. (2001, first published 1944) The Great Transformation: The Political and Economic Origins of Our Time, Boston MA: Beacon Press Books

Ramos, A. (1998) Indigenism: Ethnic Politics in Brazil, Maddison WI: University of Wisconsin Press

Ribot, J. (2014) 'Cause and Response: Vulnerability and Climate in the Anthopocene', Fournal of Peasant Studies 41.5: 667-706

Ribot, J. (2011) 'Vulnerability Before Adaptation: Toward Transformative Climate Action', Global Environmental Change 21.4: 1160-2

Ribot, J. (2006) 'Choose Democracy: Environmentalists' Social Responsibility', Global Environmental Change 16.2: 115-19

Sayer, A. (2009) 'Geography and Global Warming: Can Capitalism be Greened?', Area 41.3: 350-3

Schmitz, H. and Scoones, I. (2015) Accelerating Sustainability: Why Political Economy Matters, IDS Evidence Report 152, Brighton: IDS, 
www.ids.ac.uk/publication/accelerating-sustainability-why-politicaleconomy-matters (accessed 29 February 2016)

Scoones, I. (2015) Sustainable Livelihoods and Rural Development, Rugby: Practical Action Publishing

Smit, B.; Pilifosova, O.; Burton, I.; Challenger, B.; Huq, S.; Klein, R.J.T. and Yohe, G. (2001) 'Adaptation to Climate Change in the Context of Sustainable Development and Equity', in J. McCarthy, O. Canziana, N. Leary, D. Dokken and K. White (eds), Climate Change 2001. Impacts, Adaptations and Vulnerability, Cambridge: Cambridge University Press

Smit, B. and Wandel, J. (2006) 'Adaptation, Adaptive Capacity and Vulnerability', Global Environmental Change 16: 282-92

Smith, J. (2016) Financialised Globalisation Enhances, not Reduces, Global Inequality, www.primeeconomics.org/articles/ g1nvlzmiub7dg8bthgs 1c80n4g7msu (accessed 29 February 2016)

Smith, A. (2014) Socially Useful Production, Steps Centre Working Paper 58, Brighton: Steps Centre, http://steps-centre.org/ wp-content/uploads/Socially-Useful-Production.pdf (accessed 19 February 2016)

Smith, A. and Ely, A. (2015) 'Green Transformations from Below? The Politics of Grassroots Innovation', in I. Scoones, M. Leach and P. Newell (eds), The Politics of Green Transformations, London: Routledge/Earthscan

Stiglitz, J. (2012) The Price of Inequality: How Today's Divided Society Endangers our Future, New York NY: W.W. Norton

Stirling, A. (2014) 'Transforming Power: Social Science and the Politics of Energy Choices', Energy Research and Social Science 1: 83-95

Tanner, T.M. and Bahadur, A.V. (2013) Distilling the Characteristics of Transformational Change in a Changing Climate, Proceedings of Transformation in a Changing Climate, international conference, Oslo, 19-21 June 2013: 33-42, www.sv.uio.no/iss/english/research/ news-and-events/events/conferences-and-seminars/transformations/ proceedings-transformation-in-a-changing-climate_interactive.pdf (accessed October 2015)

Taylor, M. (2015) The Political Ecology of Adaptation: Livelihoods, Agrarian Change and the Conflicts of Development, Abingdon: Routledge

Taylor, M. (2013) 'Climate Change, Relational Vulnerability and Human Security: Rethinking Sustainable Adaptation in Agrarian Environments', Climate and Development 5.4: 318-27

Tschakert, P.; van Oort, B.; Lera St. Clair, A. and LaMadrid, A. (2013) 'Inequality and Transformation Analyses: A Complementary Lens for Addressing Vulnerability to Climate Change', Climate and Development 5.4: 340-50

Watts, M.J. (2015) 'Now and Then: The Origins of Political Ecology and the Rebirth of Adaptation as a Form of Thought', in T. Perreault, G. Bridge, and J. McCarthy (eds), The Routledge Handbook of Political Ecology, London and New York NY: Routledge

Watts, M.J. (1983) Silent Violence: Food, Famine and Peasantry in Northern Nigeria, Berkeley CA: University of California Press 
Wong, S. (2010) Elite Capture or Capture Elites?' Lessons from the 'Counterelite' and 'Co-opt-elite' Approaches in Bangladesh and Ghana, United Nations University World Institute for Development Economics Research (UNU-WIDER) Working Paper 2010/82, www.wider. unu.edu/publications/working-papers/2010/en_GB/wp2010-82/ (accessed August 2015) 


\title{
Broadening Social Protection Thinking
}

\section{Stephen Devereux and Ana Solórzano*}

\begin{abstract}
This article argues that the Institute of Development Studies (IDS) has made substantial contributions to the global social protection discourse, initially through its work on vulnerability, accountability and participatory approaches, and more recently through the work of the Centre for Social Protection (CSP) on social protection as a mechanism for achieving both economic development and social justice. These contributions are discussed at the 'ideas' level, where IDS/CSP has contributed three influential conceptual frameworks - 'transformative', 'adaptive' and 'inclusive' social protection - as well as at the 'instruments' level, where the CSP has been active in debates and policy processes from programme design through to impact evaluation.
\end{abstract}

\section{Introduction}

The social protection agenda has grown steadily in the last two decades. From its original conception as 'social safety nets' to more complex programmes with sophisticated theories of change, social protection is now mainstreamed in development programming. Countries and donor agencies across the world have adopted social protection strategies to complement and strengthen their efforts at reducing poverty and vulnerability. Within this evolution, an ideological tension underpins social protection's ultimate goal: is it primarily a means to achieve economic development targets (an 'instrumentalist' agenda), or is it a means to achieve social justice (an 'activist' agenda)? These two highly politicised narratives have influenced technical choices in social protection policy design, implementation and evaluation, reflecting the power of global development agencies as well as the nature of the social contract negotiated between the state and citizens in each country context.

We argue that the Institute of Development Studies (IDS) has influenced this debate by challenging development orthodoxies throughout its half-century of existence, and that this tradition pointed the way towards a progressive alternative to 'social protection as safety nets' thinking. IDS' work over several decades - on topics such as 
vulnerability, food security, participation, empowerment and social justice - all laid the foundations for a rights-based approach to social protection. More directly, the Centre for Social Protection (CSP), established at IDS in 2006, has developed several frameworks as conceptual contributions to this alternative paradigm.

Section 2 of this article briefly reviews the origins of social protection and its evolution within the global development policy agenda. Section 3 reflects on the main contributions of IDS to the global social protection discourse, divided into 'ideas' and 'instruments'. Section 4 concludes by briefly reflecting on future social protection trajectories.

\section{Where did social protection come from?}

Until the 1980s social protection in the developing world was dominated by the Bismarckian model of social security, with an emphasis on employment-related social insurance, following the International Labour Organization (ILO) 'minimum standards' categories (ILO 1952). ${ }^{1}$ This meant that social protection targeted mainly formally employed workers, who paid contributions into unemployment insurance and pension funds that protected them against income shocks if they lost their jobs or retired from work.

This left self-employed and informal sector workers excluded from any formal social security arrangements. However, in low-income economies the formal sector employs only a small minority of the workforce, while the majority make their livelihood as subsistence-oriented farmers, urban street traders and informal service providers, and a significant proportion of youth and working-age adults are unemployed, having never made any social security contributions.

All these categories of poor and vulnerable people had no access to social protection, except possibly humanitarian assistance in emergencies (such as food aid during droughts). Social assistance to the poor, especially 'handouts' of food or cash, was seen as economically harmful - potentially causing 'dependency syndrome' by discouraging beneficiaries from looking for work - and as fiscally unaffordable at the scale required in countries with high poverty rates and a small tax base.

A series of events in the 1980s and 1990s increased income insecurity across the world, and exposed the limitations of the social security model. These shocks and processes included:

structural adjustment programmes, that cost millions of civil servants their jobs and imposed cutbacks in government spending on food subsidies and essential social services;

political and economic transitions in former socialist economies of Europe and Asia, that were accompanied by an erosion of the 'cradle to grave' social protection that citizens had been entitled to receive from the state; 
mass mortality famines in Ethiopia, Sudan, North Korea and elsewhere, which were increasingly understood as 'human-made' rather than 'natural' disasters;

the HIV and AIDS pandemic, that 'hollowed out' families by attacking working adults, leaving behind orphans without carers or living with grandparents in 'skip generation' households;

the Asian financial crisis that, like public sector reform programmes, also displaced millions of workers from the formal sector into the informal economy or unemployment; and

ongoing 'informalisation' in labour markets worldwide, that has created a 'precariat' class of workers (Standing 2011) with insecure employment and no social security benefits.

Instead of social security and 'decent work' conditions being steadily extended to cover higher proportions of the workforce, following a linear 'modernisation' paradigm, social security access and benefits as well as workers' rights were increasingly threatened and reduced. People were left to rely on their own resources or on informal social protection, which proved inadequate to meet the range of vulnerabilities and depth of needs.

The immediate response by many governments was to introduce 'social safety nets', mainly in the form of in-kind transfers and public works, which were designed to support affected people through a transitional period (Barrientos and Santibañez 2009). Livelihood packages such as the Programme of Actions to Mitigate the Social Costs of Adjustment (PAMSCAD) in Ghana provided some relief, but only to a small number of people for a limited period. More structured and comprehensive alternatives to these residual and reactive interventions were needed.

At the end of the 1990s the World Bank launched the first globally influential social protection framework: 'social risk management' (Holzmann and Jørgensen 1999). This approach understood poverty as being driven and exacerbated by uninsured risk, and asserted that risk management is fundamental for economic growth. The World Bank subsequently published its Social Protection Sector Strategy: From Safety Net to Springboard (World Bank 2001), which identified three main objectives for social protection: it should contribute to jobs, security and equity. The underlying paradigm was based on the imperative of economic growth and trickle-down economics. Pro-poor services and programmes are relevant only to the extent to which they are a means to increase economic growth, and this will only be achieved through trade and capital market liberalisation, urban job creation, deregulation and privatisation.

In the first decade of the 2000 s social protection became internationally recognised as an entry-point for poverty reduction. To a large extent, this was a consequence of the economic crisis that occurred during the 1990s and the associated increased levels of poverty and inequality. 
A pro-poor growth approach to economic policy emerged, where economic growth was to be achieved by paying due attention to poor and vulnerable populations. In this context, many countries implemented social protection programmes such as conditional cash transfers, social grants and 'productive safety nets' on a large scale, targeting millions of poor households. Famous examples include Bolsa Família in Brazil and Oportunidades in Mexico, the Productive Safety Net Programme in Ethiopia and the Child Support Grant in South Africa, all of which were evaluated as successful in terms of achieving a number of desirable outcomes. Social protection, as a key mechanism for poverty alleviation and enhanced access to essential services, gathered political support in the global development discourse. It became a 'silent partner' (Fiszbein, Kanbur and Yemtsov 2013: 4) for the achievement of the Millennium Development Goals (MDGs).

Nonetheless, the social protection discourse was deeply divided, not only on technical questions like how - and whether - to target the poor, or whether cash transfers should be made conditional on children attending health clinics and schools, but more fundamentally, on the diametrically opposed ideological visions of society that were encapsulated in these ostensibly 'technical' choices (Kabeer 2007, 2014). The two visions can be categorised as an 'instrumentalist' approach and an 'activist' approach (Devereux and Sabates-Wheeler 2007). The former is reflected in the 'social risk management' framework, and draws from orthodox economics to hypothesise that social protection, by helping poor people manage risk better, is efficient for development. The 'activist' approach advocates for social protection as a right and a vehicle for achieving social justice, for instance by establishing a 'universal social minimum' as a right of citizenship (Thomson 2007). This thinking draws from sociology and politics as well as development studies, and asserts that poverty is embedded in complex social and political contexts that create social as well as economic risks, which interact with and reinforce each other.

After the financial crisis in 2008 there was a stronger recognition of rights-based approaches to social protection. The International Labour Office (ILO) and the World Health Organization (WHO) introduced their 'Social Protection Floor Initiative' (ILO and WHO 2009). In 2012 the International Labour Conference adopted the 'Social Protection Floors Recommendation', which encourages member states to establish rights-based social protection floors as a fundamental element of their national social security systems, to ensure progressively higher levels of social protection throughout the life-cycle (ILO 2012). In the context of the post-2015 development agenda, agencies representing both the 'activist' and 'instrumentalist' strands of the discourse - the ILO and the World Bank - are now collaborating on the 'universal social protection' agenda, concurring that social protection systems are 'an essential part of National Development Strategies to achieve inclusive growth and sustainable development with equitable social outcomes' (ILO and World Bank 2015: 1). 
Currently, an estimated 1.9 billion people in the world receive social safety net programmes in the form of conditional or unconditional cash transfers; nutritional feeding programmes; public works programmes; and/or fee waivers. Likewise, virtually every country in the world has at least one social safety net programme in place. Nevertheless, only one third of the world's poor are covered by these social protection programmes (Honorati, Gentilini and Yemtsov 2015).

\section{What has IDS contributed to social protection thinking and practice?}

IDS' specific contributions to the evolution of the global social protection discourse are twofold. Firstly, IDS has influenced the conceptualisation of social protection - what it is and what it is for ('ideas'). Secondly, IDS has informed the design, implementation and evaluation of social protection policies and interventions - what to do and how to do it ('instruments').

However, several strands of IDS work influenced the genesis and evolution of the global social protection agenda, even before it emerged as a central pillar of development policy in the early 2000s. This includes IDS work on conceptualising vulnerability (Chambers 1989; Swift 1989a), policy responses to food insecurity (Swift 1989b; Maxwell 1991) and linking relief and development (Maxwell 1994), as well as the political economy analysis of instruments such as public works, school feeding programmes and food aid (Singer, Wood and Jennings 1987).

\subsection{Ideas}

IDS contributes to the development discourse by engaging directly with topical debates and by asking questions that challenge mainstream thinking and practice, to move development policies and programmes forward in a socially progressive direction. As social protection has evolved, IDS has played various roles, ranging from enthusiastic proponent to critical friend.

In the 1980s, Robert Chambers' thinking on policy responses to vulnerability anticipated the social protection agenda by at least a decade. In a classic 1989 IDS Bulletin article, ${ }^{2}$ Chambers observed that: 'Vulnerability... is not the same as poverty. It means not lack or want, but defencelessness, insecurity, and exposure to risk, shocks and stress.' It follows that ' $[\mathrm{p}]$ rogrammes and policies to reduce vulnerability - to make more secure - are not, one for one, the same as programmes and policies to reduce poverty - to raise incomes'. Nonetheless, given the devastating consequences of risks and shocks, especially but not only for poor people, '[r] educing vulnerability can be as important an objective as reducing poverty' (Chambers 1989: 1, 5).

This fundamental distinction seems to have been forgotten by many governments and international development agencies, who have appropriated social protection for the poverty reduction agenda. Making the 'business case' for social protection and demonstrating its 'value-for-money' increasingly requires demonstrating its contribution to reducing income poverty. But this was not the original intention. Social 
protection was originally conceived as a mechanism for managing uninsured risk and minimising the damaging consequences of life-cycle stresses and livelihood shocks; it was never intended as a mechanism for propelling people out of poverty.

Early approaches to social protection, such as the World Bank's 'social risk management' framework, which emerged out of the social safety nets and social security paradigms, were oriented towards protecting economically vulnerable people against livelihood-related risks, such as unemployment and retirement. The basic tools of social insurance and social assistance were clearly essential, but IDS felt that social protection should equally be about protecting socially vulnerable people and achieving social inclusion and social justice. In 2004 IDS published a working paper called Transformative Social Protection (Devereux and Sabates-Wheeler 2004) that argued for a focus on social equity and a rights-based approach. Transformative social protection has subsequently been adopted or adapted by several agencies (including UNICEF and the World Bank) to orient their development support and programming, and by several countries (including Rwanda and Zambia) to frame their National Social Protection Strategy or Policy.

The IDS Bulletin has always offered a platform for exploring issues in a more engaging way than is possible in peer-reviewed academic journals. ${ }^{3}$ For example, in 2007 a special issue titled Debating Social Protection invited the originators of the World Bank's Social Risk Management and IDS' Transformative Social Protection frameworks to present their approaches and have them critically scrutinised - including by IDS MA students - following which the proponents were given a right to reply. Other contributions took the form of pithy articles that took sides for or against hot topics in social protection, such as cash versus food transfers, targeted versus universal programmes, and conditional versus unconditional social grants. The devil's advocate tone was set by the anti-conditionality paper, provocatively titled 'Superfluous, Pernicious, Atrocious and Abominable? The Case against Conditional Cash Transfers' (Freeland 2007). ${ }^{4}$

Migration poses particular challenges and dilemmas for social protection worldwide - an issue that became highly topical in 2015 with the so-called 'migrant crisis' in Europe. At the legal and ethical levels, should social rights and claims to social protection be 'portable' across borders, and do host countries have a responsibility to ensure that non-citizens have access to domestic social protection schemes? IDS research together with the Sussex Centre for Migration Research culminated in several articles and a book in which Sabates-Wheeler and Feldman (2011) explored the ways in which legal, physical and political environments influence the extent to which poor, and often irregular, migrants are able to access and benefit from social protection. This work drew on policy analysis and case studies of migrants in Africa, Asia, Europe and Latin America.

As global policy attention shifted towards climate change and resilience, IDS engaged by bringing together the three linked policy arenas of 
climate change adaptation (CCA), disaster risk reduction (DRR) and social protection (SP), in a synthesised framework called 'adaptive social protection' (Davies et al. 2008), which highlighted the potential for social protection to reduce or manage vulnerability to future climatic risk, while achieving socially just outcomes. An IDS/CSP working paper with another provocative title, Resilience: New Utopia or New Tyranny?, pointed out that resilience 'is not a pro-poor concept, and the objective of poverty reduction cannot simply be substituted by resilience building' (Béné et al. 2012: 3).

A new IDS/CSP working paper 'Can Social Protection Increase Resilience to Climate Change?' (Solórzano 2016) shows how conventional forms of social protection, such as Oportunidades, a conditional cash transfer programme in Mexico, have limited impact on building households' resilience. The role of these programmes is mainly preventative, by increasing the adoption of self-insurance mechanisms and anticipation of risk behaviour. The paper cautions against expectations that households will develop strong and secure livelihoods in order to adapt to climate change as a consequence of productivity-enhancing safety nets. Adaptive capacity is dependent on other factors over which social protection has very little influence. However, the safety net role of social protection is fundamental to reduce vulnerability to climate change.

In 2010 the CSP partnered with the Overseas Development Institute (ODI) and others to produce two online briefing papers - 'Social Protection in Africa: Where Next?' and 'Social Protection in Africa: A Way Forward' (CSP et al. 2010a, 2010b) - which argued against complacency and warned that the rapid gains achieved during social protection's 'honeymoon decade' could be lost just as rapidly if it turned into just another development fashion. Ten guiding principles were proposed to guide the engagement of development partners with social protection policy processes in Africa, including 'Support national policy priorities' to ensure that policies and programmes are nationally owned rather than replicating standardised imported models.

In 2011 IDS hosted a conference titled 'Social Protection for Social Justice', which reinforced the argument that a transformative approach to social protection should address social injustices and iniquitous power relations as well as material deprivations. Several participants argued for upgrading social protection from charitable donations to a justiciable right: 'From social protection recipients to citizens', according to the subtitle of one contribution to the subsequent IDS Bulletin (Tessitore 2011). The conference concluded that adopting this political rather than technocratic approach to social protection has profound implications for local, national and global governance, such as the need to ground social protection in a social contract and to establish effective accountability mechanisms (Chopra and te Lintelo 2011).

The CSP's contribution to the post-MDG discussion was 'inclusive social protection' (Roelen and Devereux 2013), which argues for extending 
coverage, institutionalising and building social protection systems, and moving explicitly towards a rights-based approach. These themes and preoccupations are mirrored by powerful actors such as the United Nations agencies which campaigned successfully to get social protection into the Sustainable Development Goals (SDGs) - notably as Target 3 under Goal 1: 'Implement nationally appropriate social protection systems and measures for all, including floors, and by 2030 achieve substantial coverage of the poor and the vulnerable' (UN DESA 2015).

\subsection{Instruments}

IDS' approach to social protection resonates with calls to put people at the centre of development programming. Complementing his conceptual work on vulnerability versus poverty, Chambers' championing of participatory approaches has been seminal in the shift from top-down to bottom-up approaches in development programming. Chambers and colleagues emphasised the importance of 'putting poor people first' throughout the project cycle, from programme design to implementation and evaluation in this IDS Bulletin. Increasing community participation in identifying poor and vulnerable people is one way of ensuring local ownership of targeting decisions, for instance. While community-based targeting raises many challenges, such as the potential for 'elite capture' of benefits, later work has provided answers on how more effective participatory processes can overcome this tendency (Chambers 2014).

Related strands of IDS work over the years - notably in areas such as power and empowerment - have informed thinking on integrating rights into social protection programmes. IDS fully supports bottom-up accountability mechanisms such as social audits and grievance procedures or 'complaint response mechanisms' to rectify targeting errors and ensure that all citizens and residents claim their right to social protection as an entitlement (Goetz and Gaventa 2001; Vij 2011). Cornwall and Gaventa (2001) argued for an actor-oriented approach to participation, whereby recipients of social policies are empowered to act as citizens on their own behalf, as opposed to functional concepts of participation that frame recipients exclusively as 'users' or 'consumers' of predetermined public services. By expanding participation into more active citizen engagement, social rights and responsibilities are included, exercised through selfaction and regulated through social accountability mechanisms.

Social protection emerged partly out of 'safety net' responses to food insecurity, especially in sub-Saharan Africa and South Asia. IDS' work on food security dates back to the Institute's founding in the 1960s. Throughout the 1970s and 1980s, IDS engaged critically with food aid as an instrument to address humanitarian crises (e.g. emergency food aid), seasonal hunger (e.g. public works programmes) and chronic hunger (e.g. school feeding schemes). In Food Aid: The Challenge and the Opportunity, Hans Singer and co-authors asked prescient questions that anticipated the 'cash versus food' debate some 20 years later: 'Is food aid doing more harm than good?... Would a cheque not be better than food?' (Singer et al. 1987). More recently, IDS led a report for the Committee on World 
Food Security on how social protection can contribute to realising the right to adequate food for all, which included a proposal for a 'food security floor' to complement the 'social protection floor' (HLPE 2012).

School feeding and public works (food- or cash-for-work) are now considered as indispensable instruments in the social protection toolkit, but they have also been subjected to critical scrutiny, by IDS and others. Old-style school feeding schemes were criticised for 'dumping' Western food aid in low-income countries, undermining local agricultural production and trade. Recently, 'home-grown school feeding' (HGSF) has emerged as an alternative approach that contracts local farmers to supply food and local caterers to prepare school meals, creating 'structured demand' to stimulate local production while ensuring that schoolchildren receive meals that are compatible with local diets. Despite its intuitively appealing theory of change, Sumberg and Sabates-Wheeler (2011: 341) question whether HGSF can actually 'promote transformational change in family farming systems' and deliver social protection and agricultural development simultaneously, or are there tensions between the social and economic objectives that could compromise both outcomes?

IDS has supported the shift in public works, from discretionary temporary 'workfare' programmes towards demand-driven 'right to work' programmes, as exemplified by the employment guarantee schemes in India. Joshi and Moore (2000) explored whether the Maharashtra Employment Guarantee Scheme (MEGS) in India has the potential for political mobilisation of the poor. Chopra (2014) examines the extent to which the Mahatma Gandhi National Rural Employment Guarantee Act (MGNREGA) represents an effective pathway towards establishing a rights-based social contract in India.

In Ethiopia, IDS has been influential in debates about using public works as both an employment-based safety net and a developmental tool since the 1990s, when food-for-work was seen as a mechanism for 'linking relief and development' (Maxwell 1993; Maxwell and Lirenso 1994). This thinking evolved into the Productive Safety Net Programme (PSNP), which was launched in 2005 and comprised Public Works (temporary employment on community infrastructure projects for food-insecure people who can work) and Direct Support (free food or cash transfers for food-insecure people who cannot work). The CSP has engaged continuously in design debates and evaluations of the PSNP, including exploring how it can be adapted from highland farming communities to lowland (agro-)pastoralist communities (Sabates-Wheeler, Lind and Hoddinott 2013), and arguing that Direct Support should evolve into one pillar of a 'comprehensive institutionalised social protection system for all vulnerable Ethiopians’ (Devereux and Teshome 2013: 101).

Recently, 'graduation model' programmes have enjoyed attention and popularity, because of their claims - backed up by evaluation evidence from several countries - to be able to graduate people sustainably out of extreme poverty, by delivering a carefully sequenced package of support 
for a period of about two years (Banerjee et al. 2015). These interventions bring together elements of social protection (cash transfers, financial inclusion) and livelihood programmes (asset transfers and skills training). They are popular with governments and agencies who are attracted by the evidence of success and the promise of an 'exit strategy'. The CSP cautioned against overambitious expectations, and proposed a framework for analysing the factors that 'enable' or 'constrain' graduation outcomes in practice (Sabates-Wheeler and Devereux 2013). In 2014 the CSP hosted an international conference in Rwanda to share experiences from the original graduation projects in Bangladesh with researchers, policymakers and practitioners from Africa, Latin America and other Asian countries. The CSP's contributions included the idea of 'intergenerational graduation', which argues that graduation can only be considered truly sustainable if children grow up better-off than their parents (Roelen 2015).

\section{Conclusion}

Social protection has come a long way in a short time, and it looks like it is here to stay. Where is it going next? In 2014 the CSP convened online discussions and ran Foresight scenario workshops to address this question: 'Where next for social protection?' (Devereux, Roelen and Ulrichs 2015). Key drivers that were predicted to influence the evolution of social protection in the coming years include widening inequalities, demographic ageing in some countries and youthful populations in others, large-scale migration and urbanisation with implications for social protection 'portability', and ongoing 'flexibilisation' of labour markets with associated loss of social security benefits.

Instead of a linear convergence towards a single model, multiple trajectories are likely, depending on political ideologies and institutional capacities in each country at different points in time. Progressive governments with adequate financial and human resources might adopt rights-based approaches such as a universal Social Protection Floor, while regressive governments with limited resources will continue to favour minimal safety nets targeting subgroups among the poor.

Social protection is a richly rewarding area of development policy to work in, because it offers a direct pathway from thinking and research to policy influence, and because the impacts are visible almost immediately, in new or improved programmes that are bringing positive changes to the lives of millions of poor and vulnerable people. Many technical and ideological debates in social protection remain hotly contested, and advocating for 'what's right' is as important as building the evidence base on 'what works'.

In the coming years, IDS and the CSP will continue to argue for a social justice approach, and will support efforts to build or strengthen national social protection systems in low- and middle-income countries. This implies not just scaling up social protection projects and extending their coverage, but recognising that social protection is just one component of an integrated strategy to reduce vulnerability and achieve social justice for all. 


\section{Notes}

* The authors are grateful to Rachel Sabates-Wheeler and Keetie Roelen and an anonymous reviewer for their insightful comments on earlier drafts of this article.

1 The Social Security (Minimum Standards) Convention, 1952 (No. 102) provides for nine contingencies: medical care and family benefits, as well as benefits in the event of sickness, unemployment, old age, employment injury, maternity, invalidity and death of the breadwinner.

2 This article was selected as a 'classic' contribution in a compilation that celebrated 40 years of the IDS Bulletin, ten years ago (Devereux and Knowles 2006).

3 Early issues of the IDS Bulletin included this frontispiece: 'The major aim of the Bulletin is to publish brief and direct - sometimes provocative - articles on themes of current importance to those concerned with problems of development: students, teachers, and above all, practitioners'.

4 The author explained his choice of title: 'In his comic novel of [1817], "Melincourt", Thomas Love Peacock wrote of the trade in sugar that it was "economically superfluous, physically pernicious, morally atrocious and politically abominable". Much the same could be said of 'Conditional Cash Transfers' (CCTs) today' (Freeland 2007: 75).

\section{References}

Banerjee, A.; Duflo, E.; Goldberg, N.; Karlan, D.; Osei, R.; Parienté, W.; Shapiro, J.; Thuysbaert, B. and Udry, C. (2015) 'A Multifaceted Program Causes Lasting Progress for the Very Poor: Evidence from Six Countries', Science 348.1260799: 1-16

Barrientos, A. and Santibañez, C. (2009) 'New Forms of Social Assistance and the Evolution of Social Protection in Latin America', Fournal of Latin American Studies 41.1: 1-26

Béné, C.; Godfrey Wood, R.; Newsham, A. and Davies, M. (2012) Resilience: New Utopia or New Tyranny? Reflection about the Potentials and Limits of the Concept of Resilience in Relation to Vulnerability Reduction Programmes, IDS Working Paper 405/CSP Working Paper 006, Brighton: Centre for Social Protection, IDS

Chambers, R. (2014) Good Practices for Effective Participation in Social Protection Design and Implementation, Geneva: United Nations Research Institute for Social Development, www.unrisd.org/unrisd/website/newsview. nsf/0/7A7C8F4B1D5C2E9BC1257CA80058501B?OpenDocument (accessed 3 November 2015)

Chambers, R. (1989) 'Editorial Introduction: Vulnerability, Coping and Policy', IDS Bulletin 20.2: 1-7, http://bulletin.ids.ac.uk/idsbo/ article/view/1821 (accessed 8 April 2016)

Chopra, D. (2014) 'The Mahatma Gandhi National Rural Employment Guarantee Act, India: Examining Pathways Towards Establishing Rights-Based Social Contracts', European Fournal of Development Research 26.3: 355-69 
Chopra, D. and te Lintelo, D. (2011) 'Democratic Governance for Social Justice: The Politics of Social Protection', IDS Bulletin 42.6: 10-12, http://bulletin.ids.ac.uk/idsbo/article/view/355 (accessed 4 March 2016)

Cornwall, A. and Gaventa, J. (2001) From Users and Choosers to Makers and Shapers: Repositioning Participation in Social Policy, IDS Working Paper 127, Brighton: IDS

CSP (Centre for Social Protection), Overseas Development Institute (ODI), School of International Development at the University of East Anglia (UEA-DEV) and Regional Hunger and Vulnerability Programme (RHVP) (2010a) Social Protection in Africa: Where Next?, www.ids.ac.uk/files/dmfile/SocialProtectioninAfricaWhereNext.pdf (accessed 3 October 2015)

CSP (Centre for Social Protection), Overseas Development Institute (ODI), School of International Development at the University of East Anglia (UEA-DEV) and Regional Hunger and Vulnerability Programme (RHVP) (2010b) Social Protection in Africa: A Way Forward, www.ids.ac.uk/news/new-approach-to-social-protection-in-africaannounced (accessed 3 October 2015)

Davies, M.; Guenther, B.; Leavy, J.; Mitchell, T. and Tanner, T. (2008) "Adaptive Social Protection": Synergies for Poverty Reduction', IDS Bulletin 39.4: 105-12, http://bulletin.ids.ac.uk/idsbo/article/ view/752 (accessed 4 March 2016)

Devereux, S. and Knowles, C. (eds) (2006) 'Challenging Orthodoxies, Influencing Debates', IDS Bulletin 37.4, http://bulletin.ids.ac.uk/ idsbo/issue/view/66 (accessed 4 March 2016)

Devereux, S. and Sabates-Wheeler, R. (2007) 'Editorial Introduction: Debating Social Protection', IDS Bulletin 38.3: 1-7, http://bulletin.ids.ac.uk/idsbo/article/view/836 (accessed 4 March 2016)

Devereux, S. and Sabates-Wheeler, R. (2004) Transformative Social Protection, IDS Working Paper 232, Brighton: IDS

Devereux, S. and Teshome, A. (2013) 'From Safety Nets to Social Protection: Options for Direct Support Beneficiaries of the Productive Safety Net Programme', in D. Rahmato, A. Pankhurst and J-G. van Uffelen (eds), Food Security, Safety Nets and Social Protection in Ethiopia, Addis Ababa: Forum for Social Studies

Devereux, S.; Roelen, K. and Ulrichs, M. (2015) Where Next for Social Protection?, IDS Evidence Report 124, Brighton: IDS

Freeland, N. (2007) 'Superfluous, Pernicious, Atrocious and Abominable? The Case Against Conditional Cash Transfers', IDS Bulletin 38.3: 75-8, http://bulletin.ids.ac.uk/idsbo/article/view/855 (accessed 4 March 2016)

Fiszbein, A.; Kanbur, R. and Yemtsov, R. (2013) Social Protection, Poverty and the Post-2015 Agenda, Policy Research Working Paper 6469, Washington DC: World Bank

Goetz, A.M. and Gaventa, J. (2001) Bringing Citizen Voice and Client Focus into Service Delivery, IDS Working Paper 138, Brighton: IDS 
HLPE (2012) Social Protection for Food Security, report by the High Level Panel of Experts (HLPE) on Food Security and Nutrition of the Committee on World Food Security (CFS), Rome: CFS

Holzmann, R. and Jørgensen, S. (1999) Social Risk Management: A Nerw Conceptual Framework for Social Protection and Beyond, Social Protection Discussion Paper 6, Washington DC: World Bank

Honorati, M.; Gentilini, U. and Yemtsov, R.G. (2015) The State of Social Safety Nets 2015, World Bank, http://documents.worldbank. org/curated/en/2015/07/24741765/state-social-safety-nets-2015 (accessed 15 February 2016)

ILO (2012) Social Protection Floors Recommendation 202, Geneva: International Labour Organization, www.ilo.org/dyn/normlex/ en/f?p=NORMLEXPUB:12100:0::NO::P12100_INSTRUMENT_ ID:3065524 (accessed 30 October 2015)

ILO (1952) Social Security (Minimum Standards) Convention 102, Geneva: International Labour Organization, www.ilo.org/dyn/normlex/en/ f?p=NORMLEXPUB:12100:0::NO::p12100_instrument_id:312247 (accessed 30 October 2015)

ILO and WHO (2009) The Social Protection Floor: A foint Crisis Initiative of the UN Chief Executives Board for Co-ordination on the Social Protection Floor, Geneva: International Labour Office and World Health Organization

ILO and World Bank (2015) A Shared Mission for Universal Social Protection: Concept Note, International Labour Organization, www.ilo.org/ wcmsp5/groups/public/---dgreports/---dcomm/documents/ genericdocument/wcms_378996.pdf (accessed 30 October 2015)

Joshi, A. and Moore, M. (2000) The Mobilising Potential of Anti-Poverty Programmes, IDS Discussion Paper 374, Brighton: IDS

Kabeer, N. (2014) 'The Politics and Practicalities of Universalism: Towards a Citizen-Centred Perspective on Social Protection', European Fournal of Development Research 26.3: 338-54

Kabeer, N. (2007) 'A "Vision" Thing? Debate and Difference within the OECD-DAC Poverty Network Approaches to Social Protection', IDS Bulletin 38.3: 51-3, http://bulletin.ids.ac.uk/idsbo/article/view/848 (accessed 4 March 2016)

Maxwell, S. (ed.) (1994) 'Linking Relief and Development', IDS Bulletin 25.4, http://bulletin.ids.ac.uk/idsbo/issue/view/115 (accessed 8 April 2016)

Maxwell, S. (1993) 'Can a Cloudless Sky have a Silver Lining? The Scope for an Employment-Based Safety Net in Ethiopia', in H. Thrimm and H. Hahn (eds), Regional Food Security and Rural Infrastructure, Hamburg: Lit Verlaug Munster-Hamburg

Maxwell, S. (ed.) (1991) To Cure All Hunger: Food Policy and Food Security in Sudan, London: Intermediate Technology Publications

Maxwell, S. and Lirenso, A. (1994) 'Linking Relief and Development: An Ethiopian Case Study', IDS Bulletin 25.4: 65-76, http://bulletin.ids.ac.uk/ idsbo/article/view/1582 (accessed 8 April 2016)

Roelen, K. (2015) 'The "Twofold Investment Trap": Children and their Role in Sustainable Graduation', IDS Bulletin 46.2: 25-34, 
http://bulletin.ids.ac.uk/idsbo/article/view/107 (accessed 4 March 2016)

Roelen, K. and Devereux, S. (2013) 'Promoting Inclusive Social Protection in the Post-2015 Framework', IDS Policy Briefing 39, Brighton: IDS

Sabates-Wheeler, R. and Devereux, S. (2013) 'Sustainable Graduation from Social Protection Programmes', Development and Change 44.4: 911-38

Sabates-Wheeler, R. and Feldman, R. (eds) (2011) Migration and Social Protection: Claiming Social Rights Beyond Borders, London: Palgrave Macmillan

Sabates-Wheeler, R.; Lind, J. and Hoddinott, J. (2013) 'Implementing Social Protection in Agro-pastoralist and Pastoralist Areas: How Local Distribution Structures Moderate PSNP Outcomes in Ethiopia', World Development 50: 1-12

Singer, H.; Wood, J. and Jennings, T. (1987) Food Aid: The Challenge and the Opportunity, Oxford: Oxford University Press

Solórzano, A. (2016) Can Social Protection Increase Resilience to Climate Change? A Case Study of the Oportunidades Programme in Rural Yucatan, Mexico, IDS/CSP Working Paper 465/13, Brighton: IDS

Standing, G. (2011) The Precariat: The New Dangerous Class, London: Bloomsbury Academic

Sumberg, J. and Sabates-Wheeler, R. (2011) 'Linking Agricultural Development to School Feeding in Sub-Saharan Africa: Theoretical Perspectives', Food Policy 36.3: 341-9

Swift, J. (1989a) 'Why are Rural People Vulnerable to Famine?', IDS Bulletin 20.2: 8-15, http://bulletin.ids.ac.uk/idsbo/article/ view/1823 (accessed 8 April 2016)

Swift, J. (1989b) 'Planning Against Drought and Famine in Turkana: A District Famine Contingency Plan', in T. Downing, K. Gitu and C. Kamau (eds), Coping with Drought in Kenya: National and Local Strategies, Boulder CO: Lynne Rienner

Tessitore, S. (2011) 'One Step Beyond: From Social Protection Recipients to Citizens', IDS Bulletin 42.6: 13-20, http://bulletin.ids. ac.uk/idsbo/article/view/356 (accessed 4 March 2016)

Thomson, K. (2007) 'A Universal Social Minimum as a Foundation for Citizenship', IDS Bulletin 38.3: 56-60, http://bulletin.ids.ac.uk/ idsbo/article/view/850 (accessed 4 March 2016)

United Nations Department of Economic and Social Affairs (UN DESA) (2015), Open Working Group Proposal for Sustainable Development Goals, https://sustainabledevelopment.un.org/focussdgs. html\#goall (accessed 3 October 2015)

Vij, N. (2011) 'Collaborative Governance: Analysing Social Audits in MGNREGA in India', IDS Bulletin 42.6: 28-34, http://bulletin.ids. ac.uk/idsbo/article/view/358 (accessed 4 March 2016)

World Bank (2001) Social Protection Sector Strategy: From Safety Net to Springboard, Washington DC: World Bank 


\title{
The Dialectics of Urban Form and Violence*
}

\author{
Jaideep Gupte and Hadeer Elshafie
}

\begin{abstract}
Over a 50 -year span, Institute of Development Studies (IDS) research has not focused on cities or urbanisation to the extent it might have. We find that there is good reason for cities to now be described as the 'new frontier' for international development. In particular, violence is increasingly a defining characteristic of urban living in both conflict and non-conflict settings. This has important consequences for the relatively under-researched links between urban violence, the processes of state building, and wider development goals. Benefiting from key IDS contributions to the debates on the security-development nexus, citizenship and the hybrid nature of the governance landscape, we argue that the moment is opportune for the Institute to deepen its research and policy expertise on urban violence 'in the vernacular'.
\end{abstract}

\section{Introduction}

There is good reason for cities to be described as the 'new frontier' for international development (DFID 2010). More than half of the world's people live in urban areas, and 50 per cent of these people currently live in cities with a population of 500,000 or more. Nearly all of the urban growth expected in the coming two decades is projected to occur in the developing world, with the urban population in South Asia and sub-Saharan Africa, two of the world's poorest regions, expected to double. The share of the poor living in urban areas is rising, and in a number of countries, it is rising more rapidly than the population as a whole. The urban share of poverty in eastern Asia is nearly 50 per cent, while a quarter of those living in poverty in sub-Saharan Africa are found in urban locations. This implies that one in seven people worldwide live in poverty in urban areas.

We find that over a 50-year span, Institute of Development Studies (IDS) research has not focused on cities or urbanisation to the extent it might have. The influential 'urban bias thesis' offered by Michael Lipton in the 1970s correctly identified the lopsided nature of development policies and practices that favoured urban areas to the detriment of rural populations, and research patterns at IDS reflected

(C) 2016 The Authors. IDS Bulletin (C) Institute of Development Studies | DOI: 10.19088/1968-2016.133 
this. Though we find that the majority of work in this area has occurred outside of IDS, three themes central to the understanding of the urban condition today, namely the security-development nexus, citizenship and the hybrid nature of the governance landscape, have all benefited significantly from IDS research. As we move towards an increasingly urbanised world, the moment is opportune for IDS to build on these foundational contributions.

\section{Urban bias revisited}

Unlike most other fields in development, the key academic contributions on the links between urbanisation and poverty have not been made at IDS, but elsewhere. This may partly be explained by a historical view of cities as sources of prosperity. In the mid to late 1960s, around the time when IDS was established, the urban anthropologist Jane Jacobs had already established detailed observations on how city economies work at the micro level, and how particular ways of urban living and interacting were the building blocks of prosperity. Jacobs opined that ignoring these would likely produce socioeconomic 'dynamics of decline' (Jacobs 1961). We were thus presented with a view of the world wherein 'without cities we would all be poor' (Jacobs 1969). By then, Arthur Lewis had also highlighted the significant presence of underemployment in rural areas, while Hans Singer (who was one of the first Fellows of IDS) and Raoul Prebisch had argued there was a long-run tendency for the terms of trade to adversely affect primary goods. As former IDS Director Richard Jolly puts it, 'One reason [for a rural focus to IDS research in the 1970s] was that rural issues seemed to be of overwhelming importance, in terms of population and poverty. A second may have been that economically the urban issues were taken to be a bi-product of industrialisation, which was a core focus of economic analysis of growth at the time.'

These points of view were famously consolidated into the immensely influential urban bias thesis. Put forth by Michael Lipton - in work produced at IDS - the thesis saw development policies as being systematically distorted in favour of the interests of urban areas, and poignantly, to the detriment of the majority living in rural areas (Lipton 1968, 1977). This was also once the topic of a lively debate between Dudley Seers, the first director of IDS, and Michael Lipton (see Seers and Lipton 1977). Several decades on, Lipton maintains that 'the reduction of anti-rural (specifically, anti-agricultural) price bias - a welcome side-effect of the generally undesirable State shrinkage forced on sub-Saharan Africa [where urban bias has been most severe] by fiscal crises plus outside pressures - has not, as intended and hoped by the World Bank, led to a reduction in urban bias overall. That is because, given the lack of change in the urban-rural power balance, reduced price bias has been offset by growing fiscal bias: specifically, falls in pro-rural and pro-agricultural public expenditure (agricultural research, farm output data gathering, extension, even rural law and order)'. ${ }^{2}$

The validity of this point of view cannot be refuted outright, particularly because it did reflect conditions across the developing world 
at the time in very real terms. The current poverty statistics presented at the start of this article, however, do present cause to re-examine the urban bias thesis, even if only in the context of some countries. Two decades on from the seminal works on the urban bias thesis, a collection of papers, again with contributions from IDS, laid out four critiques of the urban bias thesis, namely, (1) it neglects political institutions: the bias is not evident through all political systems or the ideological orientations of the ruling elite; (2) it neglects the impact of technological change that over time could make the rural sector more powerful; (3) it neglects that ethnic and religious identities cut across urban and rural landscapes - and this may limit the agglomeration of power solely in cities; and (4) that most often boundaries between what is urban and what is rural are at best blurred (Varshney 1993).

\section{Cities, violence and state building}

Picking up on the political economy critiques of the urban bias, recent work views cities as not only nodes of governance in the global North and South, but also ones which play a 'critical role in the processes of state consolidation, transformation and erosion' (Beall, Goodfellow and Rodgers 2013: 1). Indeed, as Charles Tilly (2010) argued, the changing relationships between cities and states can help us understand the centrality of cities in such processes. Importantly to our argument in this article, violent change is also central to these processes, but not necessarily in a socially deconstructive sense. Indeed, as revealed by Dennis Rodgers' work in Nicaragua - in certain circumstances, violence can trigger innovation and even be socially constructive. The (overseen) constructive attribute of violence should be situated within the inherent nature of how cities thrive and grow. Historically, a safe and secure city is arguably a dying city, while violence has been a characteristic of urban change (Rodgers 2015).

This does, however, need to be reconciled with key trends in the incidence of destructive violence today. Recent research points to the increasingly urban geography of violence (Buhaug and Urdal 2013; Raleigh 2015), which moves us beyond thinking of urban violence only as a periodic segment of war which is otherwise a rural phenomenon. When the violence of war does spill into urban areas, it is invariably indicative of changing strength ratios between rebels and government (see, for example, Holtermann 2014). Twenty-three of the 31 most fragile and conflictaffected countries today are projected to be significantly urban in the near future (Gupte 2016).We also know that violence against civilians during civil wars now occurs predominantly in urban areas (Raleigh 2012).

Moreover, the forms of violence that are typically associated with war or armed conflict are not the only significant modalities of urban violence. The destructive impacts of criminal and everyday violence can be more acute than traditional war - the United Nations Office on Drugs and Crime (UNODC) finds that 'by far the largest aspect of the global burden of armed violence is the deaths and injuries that occur in non-conflict or non-war settings' (Geneva Declaration Secretariat 2008: 67). Much of this violence is centred in cities (UNODC 2013). 
This brings us right to the confluence of three thematic areas - the security-development nexus (see Allouche and Lind 2013; Justino 2011; Luckham 2015), citizenship (Gaventa 2002) and the hybrid nature of the governance landscape (Cornwall and Coelho 2006) - that have each benefited tremendously from a long history of IDS research, even if this work was not directly focused on cities or urbanisation. These areas developed in a context where the state was no longer regarded as the sole or uncontested provider of security on the one hand, and on the other, there was a growing crisis of legitimacy characterising the relationship between citizens and the institutions that had an impact on their lives.

From a cities perspective, two key advances in knowledge help contemporise these debates: first, in the literature on cities as units of government, they grew to be distinct from the nation state weakened in an ever-globalised world (see, for example, Schiller and Fouron 2003). As Friedman (2003: 8) argues:

the focality of the state in identity formation is giving way to competing identities from indigenous, regional, and migratory populations. The latter has also entailed a decentralisation of resources within the state... and an increasing division of powers, between the state as the representative of the nation and the subgroups that tend to displace it.

Second, the state was increasingly described as only one of several actors centrally involved in the processes and actions that produce and mitigate violence (see, for example, Punch 2012), alongside local, non-state and other sovereign groups (Muggah 2014, 2015b). In parsing out the nature of state violence, the focus has therefore shifted away from a singular understanding of the role of the nation state, and moved towards processes of governance (Nugent 2004) and multiple sovereignties (Rodgers 2006) that come together to produce outcomes of security and insecurity. In turn, the diverse types of violent encounters so produced only bear a superficial connection with the structures of the nation state, but instead, play out in the everyday (even intimate) spaces in the city (Datta 2012).

The most complex of these relationships are invariably playing out in the cities of low- and middle-income countries (Muggah 2015a), where most of the urban population growth in the coming three decades is set to take place (United Nations 2014). It is in these contexts that everyday lived experiences of violence undermine the confidence of citizens in government systems directly, indirectly have a negative impact on livelihoods, and frequently reduces the quality and quantity of service provision (for example, across urban Maharashtra riot victimisation is positively associated with economic vulnerability and weak social interactions, as found by Gupte, Justino and Tranchant 2014). Though these impacts are varied and often characterised as hyper-local, they do collectively shape wider discussions on governance and state fragility at the national scale (Commins 2010). 


\section{The dialectics between urban form, violence and security in the vernacular}

Violence, therefore, is increasingly a defining characteristic of urban living in both conflict and non-conflict settings. It is shaped by and shapes the physical and social landscapes of urban communities. For example, fear of violence prompts the physical separation of highviolence neighbourhoods from surrounding areas, and can force women, men and children to adapt their daily life to avoid areas prone to violence on their way to work, around their homes, or when they play. Beyond the psychological impacts of such circumstances (see, for instance, review in Miller 2009), adapting one's way of living in this manner usually also has a direct financial cost resulting out of the need to build barriers, take longer routes to work, or forego livelihood opportunities due to concern for safety (see, for example, review in World Bank 2010).

As violence is 'non-linear, productive, destructive and reproductive' (ScheperHughes and Bourgois 2004: 1), it has multiple and overlapping forms, which range by virtue of their motivations (e.g. economic, political, criminal), their modalities (e.g. armed, physical, sexual, psychological), by the nature of the victims (e.g. gender-based, youth) as well as the nature of the perpetrators (e.g. gang, mob). The relative importance of these characteristics is contextspecific, with sociocultural norms and prevailing notions of what it means to live well in a city, playing as important a role as physical locations (e.g. megacity versus small towns; inner-city versus periphery).

The ways these forms of urban violence interact have important consequences on the one hand, on people's lived experiences of poverty and vulnerability, and on the other, on the processes of state building in both conflict and non-conflict settings. Some views have romanticised the relation between political systems and (absence) presence of violence. These top-down approaches to studying violence explained safety in terms of state provisions, i.e. legislations, regulations and services. However, reality speaks otherwise. There are both conceptual and empirical gaps between the state's discourse of security and that of the society. Observe for example the study by Pearce, McGee and Wheeler (2011), which studied everyday violence in Brazil, Jamaica, Mexico and Nigeria. The study found that the relationship between state-provision of security and violence was far from straightforward, and ironically, in the instances when state-security interacted with non-state actors in the name of security provision, violence increased. Having been conducted in countries with democratic political systems, the study also pointed at implications on the relation between democracy and violence. Democratic political systems are not, and should not, be viewed as guaranteed vanguards against violence in the vernacular. Quite to the contrary, societies legitimise parallel discourses of security and violence through informal channels.

This leads us to highlight the wealth of potential findings that could be elicited from the complexities of peoples' everyday realities when we adopt innovative approaches to studying urban violence. Capturing the nature of violence in everyday life requires a departure from traditional methodological tactics that focus on legal, formalised and 
institutionalised channels. But above all, researching violence requires honed communication skills by the researcher who must negotiate the space between the participant's safety and confidentiality as well as the safety of the researcher (De Silva 2009; Justino, Leavy and Valli 2009). Life histories, story-telling and video are among some of the alternative methods which we can use (Abah, Okwori and Alubo 2009). Studying violence exposes us to the deep nature of vulnerability, especially when the researcher is dealing with children. How do children perceive of violence for example? Observe this quote from Moncrieffe's study, when a little boy invited himself to a conversation that was taking place between the researcher and another child:

Miss, people always die in my community. We had a war between my community and another one and them [they] give mi [my] uncle ten shots in his head and mi next uncle say him can't teck [sic] it no more [my other uncle said he couldn't bear conditions anymore] and went to country and one youth go country and shot him. (A young man went to the country to execute him. In Jamaica, urban residents normally refer to the rural areas as 'country') (Moncrieffe 2009: 52).

From these points of view, then, violence prevention or security provision may also be seen as 'in the vernacular' (Luckham 2015: 20), that is, 'through the eyes of "end-users" of security arrangements, and how it is determined in the power laden and multi-levelled contexts of contemporary violent conflicts' (Luckham and Kirk 2013: 339). This 'end-user' approach to security, wherein security is a basic entitlement of those who are supposed to be protected, and contrasts with understandings of security as the creation and maintenance of authoritative social orders, is highly relevant to the lived experiences of violence in the city today. Observe how the 'everyday' constructs a fluid meaning of violence that reflects the immediate social and cultural environments in which people live. Take the example of David, from Mumbai, who is

a handyman who has taken on a Christian name since he works for both Hindus and Muslims, and is presently a member of one of the large Mumbai gangs, asks why people are so frightened of bullets 'after all, the [local] word for a bullet and a sweet candy is the same!' While showing me a bullet, he says he sometimes coats his goli (bullet) with jaggery to make it a proper goli (candy). 'I am then no different from the shopkeeper who sells candies; we both make a living from candies, no?' (as quoted in Gupte 2011: 190).

Our ongoing work focusing on Mumbai and Cairo, two of the developing world's great primate cities, looks at the dialectics between urban form, violence and security in the vernacular. We look at how the urban grid defines crowd behaviour in the public spaces - such as squares, bridges, alleyways, and residential and commercial zones during moments of public violence and protests, as well as how those same spaces are products of historical, socioeconomic and political processes that operate over long periods of time. These spaces also 
eventually vernacularise the provision of security. Take, for example, the beautification policies of Cairo during Khedive Isma'il's rule when the government embarked on a new urban plan that replaced narrow streets with wider ones and built many schools in the city centre (Mitchell 1988). The aim was to increase pockets of discipline and order through the building of schools. The strict systems of schools would enforce a certain public display in the city centre. Students were dressed in a uniform, they learned strict codes of conduct in schools, and this became part of the spatial fabric of the city centre. In other words, the behaviour of people in the city centre complemented the architectural façade of the city. In modern times, however, one of Khedive Isma'il's palaces became what we call today Tahrir Square - a space so popularly linked to the recent revolution that it eventually had grave consequences for state building in Egypt (Lababidi 2008; Sims 2010).

In Mumbai, a group of inner-city neighbourhoods experienced a particularly high intensity of violence during an intense phase of riots that gripped the city in 1992 and 1993, in which nearly 1,000 people were killed and more than 2,000 injured (Srikrishna 1998). Being some of the oldest, these neighbourhoods provide critical insights into how outcomes of violence and order in a contemporary mega-city are both interrelated, as well as path-dependent. Through the early twentieth century, despite the dilapidated living conditions in these neighbourhoods, they continued to attract wealthier and more established workers because of their proximity to the mills. In recent decades, however, the area has been transformed into a predominantly low-income area. Following the riots in the early 1990s, there was a steady exodus of business-owning Hindu families from the area, coupled with an inflow of poorer Muslim households who were being persecuted in other localities (as described in Masselos 2007: 176). An elevated viaduct was completed in 2002, allowing thoroughfare traffic an uninterrupted run, by-passing nearly all inner-city neighbourhoods. At the time of its construction, the flyover was heralded not only as an ingenious solution to Mumbai's traffic, but also as a symbol of urban ingenuity as it stood to be the longest viaduct in India. Much less attention was given to those neighbourhoods that fell under the shadow of the giant concrete structure, and even less to the recent history of violence that had so critically shaped the lives of those who now lived below it.

\section{Looking ahead at the next $\mathbf{5 0}$ years}

Nearly two thirds of the global population of 9.1 billion in 2050 is projected to be urban. This implies the number of people residing in cities and towns will double from 3.3 billion currently, to 6 billion in 2050 (United Nations 2014). Tokyo is the world's largest city today, with an agglomeration of 38 million inhabitants, Mumbai has just over 21 million, while Cairo is edging towards 19 million. But by 2030, the world is projected to have 41 mega-cities with more than 10 million inhabitants each. Even by the most conservative of outlooks, the drawing power of cities will continue to attract not only those migrants who come in pursuit of economic opportunities, but also the most vulnerable among us, for the same reasons. Today, most refugees 
worldwide are located in urban areas, ${ }^{3}$ and this trend is likely to consolidate further as vulnerable people flee violence and persecution to look for opportunities and services in cities in their time of crisis.

This makes understanding the dialectics between urban form, violence and security provision a critical pursuit for international development in the coming years. How will the cities that receive large influxes of vulnerable populations respond? What will be the impact on local markets and services? How will security be provided, and for whom? And conversely, dare we ask, in what situations does violence have the potential to trigger socially constructive innovations? These are some of the questions driving research on cities today. And yet, this conversation is not complete without an incrementally complex and locally rooted understanding of the lived experiences of poverty and vulnerabilities in cities (Satterthwaite 2014). This, in particular, is an area well suited for contributions from the IDS tradition of privileging bottom-up perspectives.

As we have argued, the dialectics between urban form (in all its physical, social and political avatars) and violence are key to understanding not only the everyday realities of urban life, but also the very processes that produce and sustain poverty in the world today. Returning to Dudley Seers (1979), if the purpose of development is to reduce poverty, inequality and unemployment, then we believe cities must feature prominently; not only as spaces in which each of these are in sharp evidence, but also as sociopolitical, economic entities that help us frame and understand the world in which we live.

\section{Notes}

* Acknowledgements: while any errors are our own, we would like to thank Prof. Michael Lipton, Prof. Sir Richard Jolly, Prof. Dennis Rodgers, and Prof. John Gaventa for their comments and guidance. We would also like to thank the editors of this IDS Bulletin, as well as the blind reviewer for their helpful suggestions.

1 Richard Jolly, pers. comm., 15 January 2016.

2 Michael Lipton, pers. comm., 23 December 2015.

3 As per UNHCR's 'Policy on Refugee Protection and Solutions in Urban Areas', 58 per cent of refugees worldwide are currently located in cities and towns.

\section{References}

Abah, Oga Steve; Okwori, Jenkeri Zakari and Alubo, Ogoh (2009) 'Participatory Theatre and Video: Acting Against Violence in Northern Nigeria', IDS Bulletin 40.3: 19-26, http://bulletin.ids.ac.uk/ idsbo/article/view/657 (accessed 15 March 2016)

Allouche, J. and Lind, J. (2013) A New Deal? Development and Security in a Changing World, Brighton: IDS, www.ids.ac.uk/publication/anew-deal-development-and-security-in-a-changing-world 1 (accessed 22 February 2016)

Beall, Jo; Goodfellow, Tom and Rodgers, Dennis (2013) 'Cities and Conflict in Fragile States in the Developing World', Urban Studies Special Issue: 1-19 
Buhaug, H. and Urdal, H. (2013) 'An Urbanization Bomb? Population Growth and Social Disorder in Cities', Global Environmental Change 23.1: $1-10$

Commins, Stephen (2010) 'Non-State Providers, the State, and Health in Post-Conflict Fragile States', Development in Practice 20.4-5: 594-602

Cornwall, Andrea and Coelho, Vera Schatten (eds) (2006) Spaces for Change? The Politics of Citizen Participation in New Democratic Arenas, London: Zed Books

Datta, Ayona (2012) The Illegal City: Space, Law and Gender in a Delhi Squatter Settlement (Gender, Space and Society), Farnham and Burlington VT: Ashgate

De Silva, Jani (2009) 'Researching Masculinity and Violence in Sri Lankan Politics: Subject Construction as Methodology', IDS Bulletin 40.3: 86-93, http://bulletin.ids.ac.uk/idsbo/article/view/666 (accessed 15 March 2016)

DFID (2010) Cities: The New Frontier, London: Department for International Development, www.gov.uk/government/uploads/ system/uploads/attachment_data/file/67689/cities-new-frontier.pdf (accessed 22 February 2016)

Friedman, Jonathan (2003) Globalization, the State, and Violence, Walnut Creek CA: AltaMira Press

Gaventa, John (2002) 'Introduction: Exploring Citizenship, Participation and Accountability', IDS Bulletin 33.2: 1-14, http://bulletin.ids.ac.uk/ idsbo/article/view/1210 (accessed 15 March 2016)

Geneva Declaration Secretariat (2008) The Global Burden of Armed Violence, Geneva: Geneva Declaration Secretariat and Small Arms Survey, www.genevadeclaration.org/fileadmin/docs/Global-Burdenof-Armed-Violence-full-report.pdf (accessed 22 February 2016)

Gupte, Jaideep (2016) 'Rethinking Approaches to Peace-Building and Political Settlements in an Increasingly Urbanised World', Policy Briefing 112, Brighton: IDS, www.ids.ac.uk/publication/rethinkingapproaches-to-peace-building-and-political-settlements-in-anincreasingly-urbanised-world (accessed 14 March 2016)

Gupte, Jaideep (2011) 'Linking Urban Vulnerability, Extra-Legal Security and Civil Violence: The Case of the Urban Dispossessed in Mumbai', in R. Desai and R. Sanyal (eds), Urbanizing Citizenship: Contested Spaces in Indian Cities, New Delhi: Sage

Gupte, Jaideep; Justino, Patricia and Tranchant, Jean-Pierre (2014) 'Households Amid Urban Riots: The Economic Consequences of Civil Violence in India', fournal of Conflict Resolution 58.8: 1445-73

Holtermann, Helge (2014) 'Relative Capacity and the Spread of Rebellion: Insights from Nepal', Fournal of Conflict Resolution 60.3: 501-29

Jacobs, Jane (1969) The Economy of Cities, New York NY: Random House Jacobs, Jane (1961) The Death and Life of Great American Cities, London: Cape Justino, Patricia (2011) 'War and Poverty', in Michelle Garfinkel and

Stergios Skaperdas (eds), Handbook of the Economics of Peace and Security, Oxford: Oxford University Press

Justino, Patricia; Leavy, Jennifer and Valli, Elsa (2009) 'Quantitative Methods in Contexts of Everyday Violence', IDS Bulletin 40.3: 41-9, 
http://bulletin.ids.ac.uk/idsbo/article/view/660 (accessed 8 April 2016)

Lababidi, Lesley (2008) Cairo's Street Stories Exploring the City's Statues, Squares, Bridges, Gardens, and Sidewalk Cafés, Cairo: American

University in Cairo Press

Lipton, Michael (1977) Why Poor People Stay Poor: A Study of Urban Bias in World Development, London: Temple Smith

Lipton, Michael (1968) 'Urban Bias and Agricultural Planning', IDS mimeo series, Brighton: IDS

Luckham, Robin (2015) Whose Security? Building Inclusive and Secure Societies in an Unequal and Insecure World, IDS Evidence Report 151, Brighton: IDS, www.ids.ac.uk/publication/whose-security-buildinginclusive-and-secure-societies-in-an-unequal-and-insecure-world (accessed 22 February 2016)

Luckham, Robin and Kirk, Tom (2013) 'Understanding Security in the Vernacular in Hybrid Political Contexts: A Critical Survey', Conflict, Security and Development 13.3: 339-59

Masselos, Jim (2007) 'Formal and Informal Structures of Power in Mumbai', in K. Segbers, Simon Raiser and K. Volkmann (eds), The Making of Global City Regions: Fohannesburg, Mumbai/Bombay, Sao Paolo, and Shanghai, Baltimore MD: Johns Hopkins University Press: 168-85

Miller, Laurence (2009) 'Family Survivors of Homicide: I. Symptoms, Syndromes, and Reaction Patterns', American Journal of Family Therapy 37.1: 67-79

Mitchell, T. (1988) Colonising Egypt, London: University of California Press

Moncrieffe, Joy (2009) 'Excerpt from Making and Unmaking the Young "Shotta" [Shooter]: Boundaries and (Counter)-Actions in the "Garrisons" , IDS Bulletin 40.1: 51-2, http://bulletin.ids.ac.uk/ idsbo/article/view/705 (accessed 15 March 2016)

Muggah, Robert (2015a) 'Fixing Fragile Cities', Foreign Affairs, 16 December, www.foreignaffairs.com/articles/africa/2015-01-15/ fixing-fragile-cities (accessed 22 February 2016)

Muggah, Robert (2015b) 'A Manifesto for the Fragile City', fournal of International Affairs 68.2: 19-36

Muggah, Robert (2014) 'Deconstructing the Fragile City: Exploring Insecurity, Violence and Resilience', Environment and Urbanization 26.2: 345-58

Nugent, David (2004) 'Governing States', in David Nugent and Joan Vincent (eds), A Companion to the Anthropology of Politics, Oxford: Blackwell: 198-215

Pearce, Jenny; McGee, Rosemary and Wheeler, Joanna (2011) Violence, Security and Democracy: Perverse Interfaces and Their Implications for States and Citizens in the Global South, IDS Working Paper 357, Brighton: IDS, www.ids.ac.uk/go/idspublication/violence-security-anddemocracy-working-paper (accessed 22 February 2016)

Punch, Maurice (2012) State Violence, Collusion and the Troubles: Counter Insurgency, Government Deviance and Northern Ireland, London: Pluto Press 
Raleigh, Clionadh (2015) 'Urban Violence Patterns Across African States', International Studies Review 17.1: 90-106

Raleigh, Clionadh (2012) 'Violence Against Civilians: A Disaggregated Analysis', International Interactions 38.4: 462-81

Rodgers, Dennis (2015) 'Violence and Order in the Future City', Cities, Violence and Order Blog Series, 29 September, www.ids.ac.uk/opinion/ violence-and-order-in-the-future-city (accessed 22 February 2016)

Rodgers, Dennis (2006) 'The State as a Gang: Conceptualizing the Governmentality of Violence in Contemporary Nicaragua', Critique of Anthropology 26.3: 315-30

Satterthwaite, D. (2014) The Multidimensional Poverty Index: Another Underestimate of Urban Poverty, 1 September, www.iied.org/ multidimensional-poverty-index-another-underestimate-urbanpoverty (accessed 22 February 2016)

Scheper-Hughes, Nancy and Bourgois, Phillippe (2004) 'Introduction: Making Sense of Violence', in Nancy Scheper-Hughes and Phillippe Bourgois (eds), Violence in War and Peace: An Anthology, Oxford: Blackwell

Schiller, Nina and Fouron, Georges (2003) 'Killing Me Softly: Violence, Globalization, and the Apparent State', in Jonathan Friedman (ed.), Globalization, the State, and Violence, Walnut Creek CA: AltaMira

Seers, Dudley (1979) 'The Meaning of Development, With a Postscript', in David Lehmann (ed.), Development Theory: Four Critical Studies, London: Frank Cass

Seers, Dudley and Lipton, Michael (1977) Urban Bias: Seers Versus Lipton, IDS Discussion Paper 116, Brighton: IDS

Sims, David (2010) Understanding Cairo: The Logic of a City Out of Control, New York NY: American University in Cairo Press

Srikrishna, B.N. (1998) Report of the Srikrishna Commission Appointed for Inquiry into the Riots at Mumbai During December 1992 and Fanuary 1993: Volumes I and II, Mumbai: Government of Maharashtra

Tilly, Charles (2010) 'Cities, States, and Trust Networks: Chapter 1 of Cities and States in World History', Theory and Society 39.3-4: 265-80

United Nations, Department of Economic and Social Affairs, Population Division (2014) World Urbanisation Prospects: The 2014 Revisions, http://esa.un.org/unpd/wup/highlights/wup2014highlights.pdf (accessed 22 February 2016)

UNODC (2013) Global Study on Homicide 2013: Trends/Context/Data. Research and Trend Analysis Branch (RAB), Division of Policy Analysis and Public Affairs (DPA), United Nations Office on Drugs and Crime, www.unodc.org/documents/data-and-analysis/statistics/ GSH2013/2014_GLOBAL_HOMICIDE_BOOK_web.pdf (accessed 14 March 2016)

Varshney, Ashutosh (1993) 'Introduction: Urban Bias in Perspective', Fournal of Development Studies 29.4, Special Issue: 3-22

World Bank (2010) Violence in the City: Understanding and Supporting Community Responses to Urban Violence, Washington DC: World Bank, http://siteresources.worldbank.org/EXTSOCIALDEVELOPMENT/ Resources/244362-1164107274725/Violence_in_the_City.pdf (accessed 22 February 2016) 


\title{
Challenging the Asymmetries of Power: A Review of the Institute of Development Studies (IDS) Contribution
}

\author{
Maro Pantazidou and John Gaventa*
}

\begin{abstract}
Despite the fact that power has been a key concept in social and political theory for decades, within international development a focus on understanding power relationships and how they are challenged and transformed has only recently become more central. In this article, we examine how the concept of power has been used and discussed in IDS Bulletin articles over the last five decades, reflect on IDS contributions to the concepts and practices of power in development, and speculate on what further work might shape and inspire work in this field in the future. We argue that an explicit analysis of power was largely absent from earlier issues of the IDS Bulletin, or considered in narrow economic terms. However, beginning around the 1990s, the analysis of power emerged more centrally to IDS work across many fields - including gender, knowledge, participation and livelihoods - such that today, understanding how power relations shape development is considered a core part of the IDS approach.
\end{abstract}

\section{Introduction}

'The extreme inequalities of most developing societies tend to mean that access to political power is seriously maldistributed, notwithstanding the countervailing influence of electoral politics. In power (and therefore policy) terms, in consequence, developing democracies tend to be characterized by a powerful 'core' dominated by well-resourced elites and a powerless 'periphery' of effectively disenfranchised citizens. To the extent that this is true in any given society, there would seem to be a case that a large proportion of external 'development aid' should be aimed at counter-balancing this structural asymmetry.'

Gordon White, IDS Bulletin, 1995, as a footnote in an article on the democratic developmental state

In the last two decades, power and empowerment have become increasingly part of the international development lexicon - though 
development aid is still far from being understood as counter-balancing the structural asymmetries of power, as Gordon White wished it to be some 20 years ago (see above quote). However, despite the fact that power has long been a key concept in social and political theory, within international development a focus on understanding power, how it works, and how power relationships are challenged and transformed has only become more central in recent years. In this article, we examine how power has been used and discussed in IDS Bulletin articles over the last five decades, reflect on the IDS contributions to concepts and practices of power in development, and speculate on how further work on power might shape and inspire work in this field in the future.

\section{Power: from a common sense word to an analytical framework for development}

A review of the IDS Bulletin provides an interesting intellectual history of how the concept of power has evolved over five decades within IDS, and perhaps more broadly in development studies. ${ }^{1}$

In an IDS Bulletin article of 2006, Robert Chambers observed that power is a useful word because it has a common sense rather than a difficult academic meaning (Chambers 2006). A word search of the term 'power' across the IDS Bulletin finds a number of examples of the 'common sense' usage. It appears some 1,675 times since the journal was first published in 1968. Over two thirds of this usage has been in the last 25 years and almost half of the usage since the year 2000. However, when we look for articles where 'power' appeared in the title (and therefore presumably as a more central concept) we see far less emphasis. Over the years, some 44 articles have carried 'power' in the title, and 28 of these (almost two thirds) have been since the turn of the century. In the early years, most of the uses of the term 'power' were in passing and mostly evoking its common sense meaning. Only in later years did the concept of power emerge as a more significant analytical lens for unpacking both the aims and the processes of international development.

The relatively slow take-up of the concern with power as a central concept in the IDS Bulletin (and therefore presumably in IDS work more generally) is striking when considered alongside other debates in the social sciences of the time. As a PhD student at Oxford in the early 1970s, one of the authors (John Gaventa) found debates on power to be critical topics of the day. In 1974, Steven Lukes published his influential Power: A Radical View, a book that shaped later thinking, especially on its 'hidden' and 'invisible' forms of power. Lukes' book also challenged behavioural views of power in American political science, with its tradition of work on community power (e.g. Dahl 1961), but though 'village studies' were important at IDS, the social science debates on how to study power at the community level are not reflected in IDS publications in this period. Also in the 1970s, Michel Foucault's important work on knowledge, discourse and power was published in France (Foucault 1977, 1979), and while this thinking also came to be reflected in streams of IDS work on knowledge, gender and 
development discourse, again this was not until much later. Around the same time, Freire published his Pedagogy of the Oppressed (1970), Simone de Beauvoir published on gender and power (1974), and Pierre Bourdieu published his work on structure, agency and habitus (1977) - all themes which are later picked up in IDS work, but not during the 1970 s when they were so hotly debated in the broader social sciences.

\section{A look at the early years (1968-99): moving beyond market and states}

Part of the apparent disconnect with other social science debates on power may have been disciplinary, as IDS was heavily influenced by economists at the time. The first IDS Bulletin article to focus on power in 1976 was about the control of oil supplies by OPEC, and referred to 'producer power' as well as to 'oil power' (Maull 1976). The next article didn't come until ten years later, when an article by Brett focusing on state power and economic inefficiency also examined the role of monopoly power, this time through the creation of state marketing boards (1986). A related article by the same author the following year on 'states, markets and private power' also focused on the concentration of economic power, but also briefly extended the idea to concentrations of power in civil society - which 'can be every bit as coercive over individuals as those exercised by the state and which can also exercise a degree of influence over the state' (Brett 1987: 36).

Thus up until the late 1980s, power was very rarely a central topic in the IDS Bulletin - and when it was used, it was largely in reference to state and economic power, with passing reference to civil society. Around the early 1990s, however, a series of separate articles each brought power into the conversation in ways that considerably expanded its meanings and scope, and laid the groundwork for streams of thinking about power which have continued to this day.

The first of these was an article in 1989 entitled 'Survival Strategies and Power amongst the Poorest in a West Bengal Village' (Beck 1989). Arguing that development studies must focus not only on formal institutions, the author turns to a study of informal survival strategies of the poor, suggesting also that 'power relations cannot be ignored'. Building on Chambers' work, Rural Development: Putting the Last First (1983: 157-63), he goes on to question whether outsiders can challenge local power directly. Rather, our studies

should find those 'gaps' or 'soft areas' in the village power structure - areas already used by the poor, that can bring benefits to them by exploiting the present system, and which, strengthened in the long term, could change the balance and structure of power (Beck 1989: 23).

Doing so, he argues, will challenge views that poor people are passive, and must be 'planned for' - 'or even make it acceptable to propose that poor people can make their own plans'.

The 1989 piece was followed by an important issue in 1993, edited by Gordon White, on the 'political analysis of markets'. Arguing for 
a 'power-based' view of politics, not only a 'state-based' one, White defines political analysis

in terms of the nature, distribution and exercise of power in the society as a whole [italics added], not only held by the state or market monopolies (1993: 2).

Therefore, markets also

can be seen as complex political systems with their own specific distributions of power and diverse sets of power relations (ibid.).

Drawing upon Foucault's notion of capillary power, White argues that state power becomes 'saturated' in everyday market exchanges in invisible ways, requiring investigation that goes beyond 'conventional economic analysis' to understand. In the same issue, Baland and Platteau ask, 'Are economists concerned with power?' and while concluding that they are, suggest that they have tended 'to focus on the mechanisms whereby power is exerted and reproduced while paying little attention to the basic question of its origin and formation' (1993: 18).

In a very significant article in the same issue, Alison Evans extends the critique from a gender perspective, arguing that 'the institutional approach continues to analyse economic behaviour within a social power vacuum' (1993: 29). Moreover, 'by analytically separating power relationships from market relationships and power from ideology, the neoclassical approach neutralizes the political or ideological content of economic transactions' (1993: 28), which in turn has led to major 'blind-spots' when it comes to understanding the gender differences in economic rewards and behaviour within the labour market. 'After years of empirical study', Evans writes, 'we know that gender differences in resource endowment are not simply given but are themselves the product of deeply-rooted asymmetries in status and bargaining power' (1993: 25).

In 1994 another special issue of the IDS Bulletin extended White's view of a 'power-based view of political analysis' to an examination of information, knowledge and power. In its far-reaching Introduction, Susanna Davies, then Associate Director, speculates on the impact that 'the revolution in information and communications technology' would have for the South and for development studies (over 20 years ago!). She argues that power affects the neutrality of knowledge, shapes 'whose reality counts', and affects how information is transmitted, analysed and used. 'Thus it is less the case that knowledge is power than that the use of that knowledge is an expression of power. Conversely, the inability to use knowledge is an expression of impotence' (Davies 1994: 11). In this same issue, we find Robert Chambers' well-known essay on 'All Power Deceives', in which he shows how errors in knowing by development professionals are deeply related to underlying patterns of dominance, ego and the relationships of 'uppers' and 'lowers' (1994). Anne-Marie Goetz in the same issue also shows how structured gender biases also affect how information is shaped and used (1994). 
Thus, in looking back over the early years of the IDS Bulletin, we find a relatively slow take-up of discussions of power initially, except in passing reference. Where it is discussed, it is largely in institutional terms referring to monopoly power. However, in a few short years from 1989-94, this approach is fundamentally questioned and the shoots emerge of what might be called an IDS approach to power, with the following characteristics:

a focus on the experiences and actions of the relatively powerless, which requires looking at power from the bottom up and with a sense of the potential of people's agency, rather than a study of power in the abstract;

a 'power-based' analysis of institutions (not simply an institutionallybased analysis of power), and one that looks at social relationships which cut across markets, states and civil society, including gendered relationships, requiring interdisciplinary perspectives to fully understand;

a recognition of the ways in which knowledge production and use both contribute to and reflect power relationships. ${ }^{2}$

\section{The later years (2000-15): influencing development pathways and 'applied' power}

Interestingly, the IDS Bulletin appears quieter on the theme of power during the second part of the 1990s, but then gains significant traction during the 2000s with a few key issues that place power front and centre: 'Making Rights Real: Exploring Citizenship, Participation and Accountability' (Cornwall 2002: i-x), 'Developing Rights' (Pettit and Wheeler 2005), 'Exploring Power for Change' (Eyben, Harris and Pettit 2006) and 'Negotiating Empowerment' (Cornwall and Edwards 2010). During this period, power plays a significant role in shaping both discourse and practice. On the discursive side, power as a concept is brought in as a solid analytical lens to both critically examine and influence development trends. On the practice side, an increasing interest in applied power analysis leads to new experiments with participatory research, learning and action.

While more diverse and extensive, much of this post-turn-of-the-century work on power continues to build upon and expand many of the themes which emerged in the 1989-94 period discussed earlier, as well as to refer back to the broader debates on power in the social sciences, especially the work of Lukes and Foucault. But this work is now both informed by and constitutive of a new landscape in development practice: since the early 1990s, 'participation', 'empowerment' and later on 'rights-based approaches' had gained prevalence, at least within the rhetoric if not the practice of most institutions and agencies in development.

IDS Bulletin articles of this period support the participatory, citizencentred and rights-based approach to development while simultaneously seek to argue or guard against an understanding of participation and 
empowerment that is not focused on transforming the power relations that drive inequality, poverty and marginalisation. This conceptual and political intent underpins a range of articles that problematise key themes of participation, knowledge, agency, gender, empowerment and citizen-institutions relations.

In 2004 Cornwall wrote:

A space can be emptied or filled, permeable or sealed: it can be an opening, an invitation to speak or act... Spaces can also be voided of meaning... Thinking about participation as spatial practice highlights the relations of power and constructions of citizenship that permeate any site for public engagement (2004a: 1).

In this period, the concept of spaces became central to the IDS approach and influential in problematising participation in at least three ways: by popularising the idea that there is no neutral space but that all spaces are constituted by the power relations that go on inside them; by providing legitimacy to those development actors who were pointing at the risks of 'invited' spaces during a time where 'consultation everywhere' was promoted as the solution to the democratic deficit; and by advocating the value of 'claimed' citizen spaces and the subsequent need to nurture them or to at least not stand in their way.

The following year in an issue dedicated to the 'rise of rights' in development, the editorial notes that:

one of the key differences between donor discourses on rights and bottom-up understandings of rights is that development actors are generally motivated on what is perceived as the 'need for development' to which rights are framed as a solution. By contrast, [social mobilisations]... are concerned with broad goals of social justice, access to economic resources, political change and empowerment (Pettit and Wheeler 2005: 3).

In the same volume, Just Associates ${ }^{3}$ argue that rights can be packaged as another technical fix that doesn't challenge structural inequalities and sources of power (Miller, VeneKlasen and Clark 2005).

The preoccupation with definitions and framings of rights here is one example of how power dynamics 'determine definitions of what is conceived as important' (Gaventa and Cornwall 2006: 122) and what solutions are conceived as possible, for and by whom. In another example, a seminal IDS Bulletin on 'The Politics of Seed in Africa's Green Revolution', Scoones and Thompson (2011) demonstrate how narratives shaped by power relations and institutional interests determine which development pathways - in the form of policy or technological solutions - are given importance over others and in so doing, define winners and losers in the food and seeds system. In support of creating more space for bottom-up innovations powered by farmers' knowledge, the authors state that 'this is not a romantic 
reification of the traditional, but a radical shift in doing things which bypasses and subverts the conventional approaches, so easily captured by elite forms of expertise and business interests' (2011: 17).

Building on earlier work (2006: 16) on the need to link empowerment to issues of caste and class and the unequal access of women in the power wielded by the state, as part of the 2008 issue titled 'Reclaiming Feminism: Gender and Neoliberalism', Chakravarti examines three different women's empowerment programmes in India - from the 1970s literacy campaigns to the microcredit schemes in the $2000 \mathrm{~s}-$ to demonstrate how the meaning of empowerment has been distorted into 'individual betterment', serving the neoliberal agendas of both markets and state (Chakravarti 2008).

Multiple articles emphasise the importance of not losing sight of the power of the elites - and how such power is reproduced through unequal access to resources - as a counterweight against approaches that depoliticise empowerment through 'the assumption that one sector of society can be empowered without necessarily changing the power of other sectors or questioning the norms and values that uphold that power' (Pettit and Wheeler 2005: 6). On the other hand, work by Chambers and others argue that we must go beyond the 'power-over' view, to also understand the 'power to empower' as a win-win rather than a zero-sum process (2006).

Thus, much of the more recent work on power is concerned with more deeply interrogating the transformation of power relations in practice: simplistic dichotomies of 'win-lose', 'powerful-powerless', 'mainstream vs alternative pathways for change' are consistently challenged. Energy is instead invested in asking the right questions and deepening the inquiries on and with the actors in complex social dynamics, so as to influence the course of action. For example, some of the most recent work on agency and citizenship applies concepts of 'legitimacy' and 'social leadership' to shed light on how and why certain power relationships and governance arrangements are sustained or disrupted especially within complex and volatile contexts (McGee 2014; Tadros 2014).

Articles in this period are also many times authored with or by IDS partners and practitioners from both North and South - often as a result of larger or smaller joint research projects - demonstrating a move to applying understandings of power to specific contexts and struggles, and also a move towards co-generation of knowledge as a strategy for shifting power relations in and of itself. This move is well documented in the 2012 issue 'Action Research for Development and Social Change' (Burns 2012), which provides nuanced accounts on researching power with a view to finding entry points for change together, as well as to scale up systemic participatory inquiries that engage multiple stakeholders in analysing power relations in complex systems (see, for example, the case of systemic inquiry on climate change adaptation in Harvey, Burns and Oswald 2012). 
Thus, when scanning through the proliferation of articles that are concerned with power in development after 2000 (more than two thirds of the total, as mentioned above), one encounters a diverse and rich mix of inquiries, conceptual explorations, case studies, tools and dialogues. Those evoke sometimes powerful and inspiring deep-dives in development theory and practice and other times challenges, provocations and doubts about the way forward for our understanding of power in development. If seen as more than the sum of its parts, this focus on 'applied power' has created a set of resources that in turn have arguably had an impact on how a critical mass of 'development operations think: the ideas, values, assumptions and information that shape their practice' (Kabeer 2010: 108). Specifically, these resources could be labelled as:

- Discursive: Elevating the transformation of power relations as a key precondition for development outcomes otherwise at risk of being understood as mere technical fixes (for example, good governance, citizen participation, climate change adaptation).

Analytical: Offering typologies of power that encourage a relational understanding of power (power as diluted in social relations, as formal and informal, visible, hidden and invisible, positive and negative, power as a function of complex systems) and thus enriching the available analytical frameworks for constructing theories of change within development programmes. ${ }^{4}$

- Practical: Developing and diffusing methodologies, tools, stories, examples that support an increasing number of practitioners to develop a more power-conscious practice and explore pedagogies that focus on the transformation of power relations. ${ }^{5}$

While the analysis above has looked at the emergence of work on power through a focus on key articles in the IDS Bulletin over almost five decades, this of course gives only a partial view of how the topic of power has been taken up in IDS work. If we expand our lens further, we see other examples as well. Particularly in recent years, work by the STEPS Centre and others have demonstrated the critical importance of control over resources - land, water, climate, food - as expressions of power, as well as how dominant knowledge and discourses shape the policy debates and processes of sustainability (Leach, Scoones and Stirling 2010). Work on 'unruly politics' has challenged how power is exercised and built beyond recognisable repertoires for citizen action and organisation (Khanna et al. 2013). Other work on complexity and power challenges us to move away from linear understandings of how power works, while also taking a more systems-based view (Ramalingam 2013; Burns and Worsley 2015). Yet other work has focused on the power of measurement and evaluation, raising fundamental questions about who has the power to determine 'success', and whose knowledge and values these reflect (Eyben et al. 2015). Work by the Centre for Rising Powers in Development has looked at how the rise of the BRICS is changing the global contours of power. 
The landscape of work on power at IDS in its fiftieth year thus looks very different than in its earlier years. It can now be said that power is a core concept cutting across almost all of IDS' work, as illustrated by the IDS strategy for 2015-20 which pledges 'to challenge orthodoxies, interrogate power relations, and bring the voices and realities of people... to the heart of debate and decisions' ${ }^{6}$ Yet IDS is itself entangled in relationships of power, including funding and policymaking relationships, which make certain discourses, pathways and approaches more visible or legitimate than others, and which may obscure ideological choices. IDS is also itself not a unified entity but a constellation of actors and networks with different power relations, within multiple perspectives and approaches. A unified IDS lens on power would likely be neither possible nor desirable, for it is the contestations and critiques of knowledge, both externally and from within, that sustain the evolution of approaches and perspectives.

\section{Afterword: looking back to look forward}

Writing this article has created a reflective moment for both authors. In this final section we take a conversational approach to share our thoughts on how we have experienced this history, as well as on how IDS might approach future work on power.

Both authors have had the privilege of learning from and engaging with this rich historical trajectory at IDS on power: John as a Fellow linked to the Institute for almost 20 years, and Maro first as a student, who has gone on to reflect further upon and to apply concepts to her practice as a human rights practitioner and activist (Pantazidou 2013).

In the process of tracking the intellectual journey of 'power' within the IDS Bulletin we kept asking ourselves: how did these concepts and approaches to power influence us personally - and other peers - along the way? And what can we learn from the past as we move forward? What further work might be important on the horizon? As this is very much a live conversation, we have chosen to share a part of our dialogue and to invite readers to create their own answers to the same questions, and to engage in the IDS conversation going forward.

M: John, you were the one who has seen all this work evolve through time. How did you experience this journey of developing IDS' work on power?

J: When I came to IDS in the mid-1990s, I had published the book Power and Powerlessness: Quiescence and Rebellion in an Appalachian Valley (1980), based on my earlier work in a poor community in the United States, whose history had been shaped by a large absentee mining company. I had also been highly influenced by the debates on power from the 1970s, referred to earlier. This was also a time when the wave of donor interest in 'participation in development' was rising. On the one hand it was very exciting, especially to be at a place where work on knowledge and power through Robert Chambers and 
others had been so important. On the other hand, the participation discourse at the time seemed strangely devoid of references to power, unlike my own view where participation discourse had been linked to struggles for control over decisions and resources which affected the lives of marginalised groups. Other colleagues felt similarly, and over the next decade, we saw the evolution of the group of which I was a part from a focus on 'participatory learning and action' (PLA), to 'participation', more broadly, and then to 'power, participation and social change'. The publication of the 2006 special issue of the IDS Bulletin on power, edited by Rosalind Eyben, Colette Harris and Jethro Pettit, was a particular milestone. In the run-up to this, we held a number of reading and discussion sessions trying to locate our work on power more broadly in social and political intellectual debates on power outside of development studies - whether based on the work of Foucault, Lukes, Bourdieu or others.

J: Maro, you came to IDS after the publication of this issue in 2006. Looking back, what did you find exciting and valuable about the work on power at that time? How did it contribute to what you went on to do?

M: I joined in 2009, a couple of years after the Participation team added the word Power to its name. From day one I was well aware that a lot of conversations had been had and maybe intellectual battles' had been fought to have a coherent body of work that encapsulated and propelled an approach situating power relations at the heart of the participation paradigm.

In my MA at least, the field of practice was much broader than the international development enterprise. It actively encompassed issues of social activism both in the North and South partly in line with the then trend of 'reinventing development' as a global challenge. I remember being inspired by the articles in the 'New Democratic Spaces' IDS Bulletin special issue of 2004 (Cornwall 2004b) and also by yours and Andrea Cornwall's on 'challenging the boundaries of the possible' and using participatory action research as change strategy in itself (Gaventa and Cornwall 2006). All this served as a big intellectual support to go on and do a year of action research with migrant and refugee groups in London looking both at actororiented perspectives of building agency and at the role of both more and less institutional approaches to claiming rights.

If I could summarise the main influences of this work on me, and also maybe speaking on behalf of other colleagues I talked to while preparing this article, I would say that studying power at IDS was an invitation to study personal attitudes in social change spaces and also an invitation to critically examine the relationships between different strategies for shifting power relations. For example, what is the complementarity between working with invited and closed spaces or with legally-oriented and empowerment-oriented approaches to 
change? What are the limits of this complementarity? I think this kind of thinking - checking who I am 'in the room'; who produces knowledge and framings, for whom and how; and testing my assumptions about why an approach will shift power (or not) is very present in my current work both for Amnesty International and on politics and social movements.

J: It has been inspiring to see how you have taken the concepts of power and continuously wrestled with how to apply them to your work on human rights and citizen action. While our concepts of power and our debates on how to analyse it continue at IDS, what I often feel is missing is the deep empirical application of these concepts to everyday life. How do relatively powerless groups themselves experience power in a changing world? How does it affect their strategies for action? How are the mechanisms of power changing through globalisation, the rise of the BRICS, extreme violence, rising inequality? One reason that this work may be absent is that is hard to fund. While donors accept that the notion of power is important, very few are willing to resource in-depth studies of how power works, including how the power of funding creates certain silences in development knowledge as well as development practice.

M: Yes, it's really important to look at what has been less discussed or somehow sidestepped - or where the power approach has not penetrated enough. I feel that the power concepts have interlocked with participation and rights at the level of building agency and power from below (lots of wonderful case studies on this!), or have been applied at the national level to unpack power relationships around certain sectors, most of the time understanding the 'nation state' as the level for change as demonstrated in White's quote at the beginning of this article. However, there seems to be less work that has applied the power concepts to formulate a critique or analysis of global power structures. For example, with the exception of some key special IDS Bulletins, few articles apply a deep analysis of power to 'hard' development issues - trade, health and pharmaceuticals, nutrition and food rights or on the power relationships between states and corporate and other actors.

J: I agree. For instance, my current work is on how rising economic inequalities contribute to or re-shape inequalities of power and voice. I found it very interesting to note in reviewing the IDS Bulletin articles, how the first debates on power were linked to an understanding of markets and economic power. I fear that in broadening our understanding of the spheres of power, we may have lost this attention to economic forces, and in particular how the huge concentration of wealth in the hands of a few - in both North and South - changes the contours of power and participation. But the IDS strategy for 2015-20 puts inequality squarely on our agenda. It also speaks strongly to IDS' role as one of interrogating and challenging power relations, both in what knowledge we produce and 
share, as well as how and with whom we do so. It's still an exciting place to be!

M: I totally agree about the attention to economic power. I was struck reading in the IDS Anniversary IDS Bulletin, Rosalind Eyben praised the 'brilliant timing' of the 1993 fortieth issue on 'markets and states', as it helped her fight internal struggles at the Department for International Development (DFID) in a period when Thatcherite economics dominated. I think a really important question to ask is what would be 'brilliant timing' now in our power work? What concepts and analysis would be useful for today's internal and external struggles? There are two things I would add to the mix. At the risk of oversimplifying here, we can say that it was the growing wealth inequality and the blatantly cynical politics of institutions, together with the increased connectivity between citizens that sparked the last cycle of contention in 2011-12 with citizens taking to the streets and squares from Ukraine to Brazil and Greece to India. The people's response took us from 'consultation everywhere' to 'occupation everywhere', signifying a break with old representational politics like never before. This has been followed up by efforts to build new forms of representation (for example, witnessed in new political parties) but also to create new kinds of institutions and power from below. This is very present in my experience in Greece where citizens have experimented with neighbourhood assemblies, social health centres, etc. In this landscape, I would say that what is needed now is to reinvigorate concepts of spaces for power and pick up a suggestion made in the editorial of the 2006 power issue to explore more 'how power shapes citizens' constructions of state institutions' (Eyben et al. 2006: 10) and to re-imagine what these institutions can look like in the future.

J: To our readers, we invite your thoughts as well. What are the critical issues and possibilities for power analysis today? How can we best apply White's challenge from 20 years ago to address the 'structural asymmetries' of power?

\section{Notes}

* Maro Pantazidou is a 2011 graduate from the IDS Masters programme in Power, Participation and Social Change; John Gaventa has been a Fellow at IDS since 1996, and served as Maro's thesis supervisor. They both wish to thank colleagues who shared their reflections on IDS work on power as part of preparatory conversations for this article and in particular Richard Jolly, Melissa Leach, Andrea Cornwall, Andre Ling, Christina Kelling and Ghali 'Nou.

1 To prepare this article, we started with an electronic search for the word 'power' across all issues of the IDS Bulletin (1968-2015). From this search, we chose a selection which represented the evolving application of power concepts on different themes and through differing time periods, for further study. Recognising that the IDS Bulletin only represents a partial view of IDS' work on the theme, we then supplemented this sample with other work related to power, 
particularly in the most recent period. Throughout the process, we carried out intense dialogue between ourselves, as a Fellow and former student, together developing our reflections and analysis, as well as interviews with a few Fellows and former students to gain their views.

2 The focus on knowledge was not a new theme in IDS work. An IDS Bulletin issue in 1979 edited by Robert Chambers had focused on indigenous knowledge and development, though not through a power lens (Chambers 1979).

3 Just Associates is a global women's rights network that has worked closely with the IDS Participation, Power and Social Change team in developing concepts for power analysis and collective action (www.justassociates.org).

4 For instance, the 'powercube' approach outlined in the 2006 special issue on power has been widely used as a tool for power analysis by practitioners around the world (Pantazidou 2012), while more recent work has continued to insist on how power analysis - with its focus on knowledge, relationships and agency can complement a more institutional political economy approach (Petitt and Mejia Acosta 2014).

5 See multiple tools on the powercube website (www.powercube.net) or the Practical Guide to Facilitating Social Change (Hunjan and Pettit 2011), which is based on power analysis experiences with grass-roots UK non-governmental organisations (NGOs) and networks, or the multiple videos, stories and other resources emerging from the Pathways of Women's Empowerment programme (www.pathwaysofempowerment.org).

6 www.ids.ac.uk/about-us/our-vision-and-strategy.

\section{References}

(All urls accessed 23 March 2016, unless otherwise stated.)

Baland, Jean-Marie and Platteau, Jean-Philippe (1993) 'Are Economists Concerned with Power?', IDS Bulletin 24.3: 12-20, http://bulletin.ids.ac.uk/ idsbo/article/view/1656 (accessed 23 March 2016)

Beck, Tony (1989) 'Survival Strategies and Power amongst the Poorest in a West Bengal Village', IDS Bulletin 20.2: 23-32, http://bulletin.ids.ac.uk/ idsbo/article/view/1825

Bourdieu, Pierre (1977) Outline of a Theory of Practice, Cambridge: Cambridge University Press

Brett, E.A. (1987) 'State Power and Economic Inefficiency: Explaining Political Failure in Africa', IDS Bulletin 17.1: 22-9, http://bulletin.ids.ac.uk/idsbo/article/view/2012 (accessed 12 April 2016)

Brett, E.A. (1986) 'States, Markets and Private Power in the Developing World: Problems and Possibilities', IDS Bulletin 18.3: 1-7, http://bulletin.ids.ac.uk/idsbo/article/view/1964 (accessed 12 April 2016)

Burns, Danny (ed.) (2012) 'Action Research for Development and Social Change', IDS Bulletin 43.3, http://bulletin.ids.ac.uk/idsbo/issue/ view/31 
Burns, Danny and Worsley, S. (2015) Navigating Complexity in International Development: Facilitating Sustainable Change at Scale, Rugby: Practical Action

Chakravarti, Uma (2008) 'Beyond the Mantra of Empowerment: Time to Return to Poverty, Violence and Struggle', IDS Bulletin 39.6: 10-7, http://bulletin.ids.ac.uk/idsbo/article/view/711

Chakravarti, Uma (2006) Everyday Lives, Everyday Histories: Beyond the Kings and Brahmanas of 'Ancient' India, 1st ed., Chennai: Tulika Books

Chambers, Robert (2006) 'Transforming Power: From Zero-Sum to Win-Win?', IDS Bulletin 37.6: 99-110, http://bulletin.ids.ac.uk/ idsbo/article/view/905

Chambers, Robert (1994) 'All Power Deceives', IDS Bulletin 25.2: 14-26, http://bulletin.ids.ac.uk/idsbo/article/view/1600

Chambers, Robert (1983) Rural Development: Putting the Last First, London: Longman

Chambers, Robert (ed.) (1979) 'Rural Development: Whose Knowledge Counts?', IDS Bulletin 10.2

Cornwall, Andrea (2004a) 'Introduction: New Democratic Spaces? The Politics and Dynamics of Institutionalised Participation', IDS Bulletin 35.2: 1-10, http://bulletin.ids.ac.uk/idsbo/article/view/1099

Cornwall, Andrea (2004b) 'New Democratic Spaces', IDS Bulletin 35.2, http://bulletin.ids.ac.uk/idsbo/issue/view/76

Cornwall, Andrea (2002) 'Locating Citizen Participation', IDS Bulletin 33.2: i-x, http://bulletin.ids.ac.uk/idsbo/article/view/1206 (accessed 15 March 2016)

Cornwall, Andrea and Edwards, Jenny (2010) 'Negotiating Empowerment', IDS Bulletin 41.2: 1-9, http://bulletin.ids.ac.uk/ idsbo/article/view/551

Cornwall, Andrea; Gideon, Jasmine and Wilson, Kalpana (eds) (2008) 'Reclaiming Feminism: Gender and Neoliberalism', IDS Bulletin 39.6: 1-9, http://bulletin.ids.ac.uk/idsbo/article/view/710

Dahl, Robert (1961) Who Governs? Democracy and Power in an American City, New Haven CT and London: Yale University Press

Davies, Susanna (1994) 'Introduction: Information, Knowledge and Power', IDS Bulletin 25.2: 1-13, http://bulletin.ids.ac.uk/idsbo/ article/view/1594

de Beauvoir, Simone (1974) The Second Sex, New York NY: Vintage Books

Evans, Alison (1993) “"Contracted-Out”: Some Reflections on Gender, Power and Agrarian Institutions', IDS Bulletin 24.3: 21-30, http://bulletin.ids.ac.uk/idsbo/article/view/1657

Eyben, Rosalind; Harris, Colette and Pettit, Jethro (eds) (2006) 'Exploring Power for Change', IDS Bulletin 37.6, http://bulletin.ids.ac.uk/idsbo/ article/view/896

Eyben, Rosalind; Guijt, Irene; Roche, Chris and Shutt, Cathy (2015) The Politics of Evidence and Results in International Development: Playing the Game to Change the Rules, Rugby: Practical Action Publishing

Foucault, Michel (1979) The History of Sexuality, Part 1, London: Allen Lane 
Foucault, Michel (1977) Discipline and Punishment, London: Allen Lane Freire, Paulo (1970) Pedagogy of the Oppressed, New York NY: Seabury Press

Gaventa, John (1980) Power and Powerlessness: Quiescence and Rebellion in an Appalachian Valley, Champaign IL: University of Illinois Press

Gaventa, John and Cornwall, Andrea (2006) 'Challenging the Boundaries of the Possible: Participation, Knowledge and Power', IDS Bulletin 37.6: 122-8, http://bulletin.ids.ac.uk/idsbo/article/ view/907

Gaventa, J.; Shankland, A. and Howard, J. (2002) 'Making Rights Real: Exploring Citizenship, Participation and Accountability', IDS Bulletin 33.2, http://bulletin.ids.ac.uk/idsbo/issue/view/84 (accessed 12 April 2016)

Goetz, Anne-Marie (1994) 'From Feminist Knowledge to Data for Development: The Bureaucratic Management of Information on Women and Development', IDS Bulletin 25.2: 27-36, http://bulletin.ids.ac.uk/idsbo/article/view/1601

Harvey, Blane; Burns, Danny and Oswald, Katy (2012) 'Linking Community, Radio, and Action Research on Climate Change: Reflections on a Systemic Approach', IDS Bulletin 43.3: 101-17, http://bulletin.ids.ac.uk/idsbo/article/view/314

Hunjan, Raji and Pettit, Jethro (2011) Power: A Practical Guide for Facilitating Social Change, Dunfermline: Carnegie United Kingdom Trust, Democracy and Civil Society Programme

Kabeer, Naila (2010) 'Women's Empowerment, Development Interventions and the Management of Information Flows', IDS Bulletin 41.6: 105-13, http://bulletin.ids.ac.uk/idsbo/article/view/1895

Khanna, Akshay; with Mani, P.; Patterson, Z.; Pantazidou, M. and Shqera, M. (2013) The Changing Faces of Citizen Action: A Mapping Study through an 'Unruly' Lens, IDS Working Paper 423, Brighton: IDS

Leach, Melissa; Scoones, Ian and Stirling, Andy (2010) Dynamic Sustainabilities: Technology, Environment and Social Justice, London and Washington DC: Earthscan

Lukes, Steven (1974) Power: A Radical View, London: Macmillan

Maull, Hanns (1976) 'The Preconditions for Producer Power: The OPEC Example', IDS Bulletin 7.4: 27-8

McGee, Rosemary (2014) 'Power, Violence, Citizenship and Agency', IDS Bulletin 45.5: 36-47, http://bulletin.ids.ac.uk/idsbo/article/ view/149

Miller, Valerie; VeneKlasen, Lisa and Clark, Cindy (2005) 'Rights-based Development: Linking Rights and Participation - Challenges in Thinking and Action', IDS Bulletin 36.1: 31-40, http://bulletin.ids.ac.uk/idsbo/article/view/1041

Pantazidou, Maro (2013) 'De-Constructing Marginality with Displaced People: Learning Rights from an Actor-Oriented Perspective', fournal of Human Rights Practice 5.2: 267-90

Pantazidou, Maro (2012) What Next for Power Analysis? A Review of Recent Experience with the Powercube and Related Frameworks, IDS Working Paper 400, Brighton: IDS 
Pettit, Jethro and Mejia Acosta, Andrés (2014) 'Power Above and Below the Waterline: Bridging Political Economy and Power Analysis', IDS Bulletin 45.5: 9-22, http://bulletin.ids.ac.uk/idsbo/article/ view/ 147

Pettit, Jethro and Wheeler, Joanna (eds) (2005) 'Developing Rights? Relating Discourse to Context and Practice', IDS Bulletin 36.1: 1-8, http://bulletin.ids.ac.uk/idsbo/article/view/1038

Ramalingam, Ben (2013) Aid on the Edge of Chaos: Rethinking Development in a Complex World, Oxford: Oxford University Press

Scoones, I. and Thompson, J. (2011) 'The Politics of Seed in Africa's Green Revolution: Alternative Narratives and Competing Pathways', IDS Bulletin 42.4: 1-23, http://bulletin.ids.ac.uk/idsbo/article/ view/460

Tadros, Mariz (2014) 'Devolving the Power to Divide: Sectarian Relations in Egypt (2011-12)', IDS Bulletin 45.5: 69-80, http://bulletin.ids.ac.uk/idsbo/article/view/152

White, Gordon (1995) 'Towards a Democratic Development State', IDS Bulletin 26.2: 27-36, http://bulletin.ids.ac.uk/idsbo/article/ view/ 1548

White, Gordon (ed.) (1993) 'The Political Analysis of Markets', IDS Bulletin 24.3, http://bulletin.ids.ac.uk/idsbo/issue/view/121 


\title{
Gender, Sexuality and Development: Revisiting and Reflecting*
}

\author{
Zahrah Nesbitt-Ahmed and Jenny Edwards
}

Abstract This article looks at how the Institute of Development Studies (IDS) has participated in, contributed to, and been shaped by debates around gender and sexuality. Through interviews with key participants in the gender and sexuality research story of IDS, we explore certain periods and themes over the last four decades. These are the introduction of gender research at IDS in the 1970s, the development of the MA Gender and Development (GAD) in partnership with the University of Sussex in the late 1980s; the co-construction of knowledge with the development of BRIDGE in the 1990s; and the Pathways of Women's Empowerment programme, gender myths and sexuality, and the emergence of work on men and masculinity from 2000. These selected stories highlight the particular strength of IDS' convening role in creating the spaces for academics, activists and others to come together to politicise the dialogues by revealing normative assumptions often taken for granted in gender and sexuality.

\section{Introduction}

'Thirty years of feminist engagement with development has led to the distinctive and plural field of inquiry and practice of gender and development.'

Cornwall, Harrison and Whitehead (eds), Feminisms in Development: Contradictions, Contestations and Challenges, 2007: 2

The Institute of Development Studies (IDS) turns 50 in 2016. To celebrate this important milestone, this article looks back at how the Institute has participated in and contributed to debates around gender and sexuality - in all their distinctiveness and plurality - through the decades. Beginning in the mid to late 1970s we track the progress of gender and sexuality issues within IDS and how the engagement of IDS' scholarship with them shaped, and was shaped by, external thinking.

Through interviews with key participants, we examine particular points in that narrative, exploring their contributions to the debates of their time. We have selected certain critical periods and themes from the last four decades, starting with the introduction of gender research and networks at IDS in the 1970s and the development of the MA Gender 
and Development (GAD) in partnership with the University of Sussex in the late 1980s, before we go on to explore the ways in which knowledge was co-constructed with the development of BRIDGE $^{1}$ in the 1990s. Moving into the early 2000s we discuss the development of the Pathways of Women's Empowerment programme, as well as gender myths and sexuality and the ways in which IDS helped challenge the development sector to critique 'heteronormativity' - leading to the development of programmes with international partners both for sexuality and gender. We then trace the emergence of work with and on men and masculinity from 2000 to the present - work developed as a way to break out of women-centric and individualist approaches to development.

There are many others we could also have included, but these particular stories have been selected to show how the international convening power of IDS has acted as a catalyst for debates to pose provocative questions. This has been done through creating the spaces for academics, activists and others to come together to politicise the dialogues by revealing normative assumptions often taken for granted. Working within IDS enabled its gender specialists to create international networks and fields of thought at a time when the Institute had unparalleled global reach. The importance of gender at IDS can be seen in the creation of a body of gender specialists that work in countries all over the world and in numerous international organisations, as well as its role in helping to connect international feminists. It is this fusion of people, space and creativity of thought that has been the particular strength of IDS' convening role in the field of gender and sexuality.

\section{The birth of gender studies at IDS}

The 1970s marked a significant era of change for women's organising. Second-wave feminism was well under way in the US and the UK. Amid a wave of feminist reform in areas such as abortion and contraception, the United Nations (UN) declared 1975 to be International Women's Year. A dynamic mix of global and local feminisms was ushering in a new focus on women in development activism and research. Ester Boserup's (1970) pioneering work on women's role in economic development was taken up enthusiastically, and the 1975 first world conference on the status of women held in Mexico led to the creation of many new institutions. Among them were the development of the African Training and Research Centre for Women (ATRCW) in Addis Ababa (1975), the founding of the United Nations Development Fund for Women (UNIFEM) in 1976, and the establishment of local women's movements including one of the first Africa-wide networks of women, the Association of African Women for Research and Development (AAWORD) in 1977 (Berger 2007).

With the women in development (WID) approach, social movements were aiming to 'visibilise' women (Kabeer 1994). It was, however, still an uphill struggle. As Kabeer notes: 'development [had] been [up until then] about men, by men and for men' (1994: ix). This struggle was 
paralleled in the struggle to get gender included both as a research focus and teaching programme within IDS.

Initially, this was spearheaded by a small group of feminist graduate students and early career staff from IDS and the University of Sussex, who advocated for the establishment of a Fellow in Gender at IDS (Whitehead pers. comm.). Kate Young, appointed to this post in 1977, worked to establish a research programme at IDS and to make contacts with key international scholars and academics. More informally, she was part of a group of multidisciplinary feminist researchers who came together to establish the theoretical and conceptual underpinnings to issues of gender in contexts of social and economic transformation. Kate was successful in getting funding for a major international workshop which was planned by this Subordination of Women (SOW) collective and took place at IDS in 1978. The empirical and conceptual papers given at the 'Continuing Subordination of Women in the Development Process' conference by activists and researchers from many different countries succeeded in 'developing an interdisciplinary socialist feminist approach to examine development and social change' (Rai and Waylen 2013; Young 1979a).

As Shirin Rai and Georgina Waylen write in New Frontiers in Feminist Political Economy, the SOW conference's 'debates on GAD [gender and development], production and reproduction are now legendary and are still as relevant today as they were then' (2013: 3). The SOW collective and the 1978 conference played an important role in critiquing the WID approach. WID was seen as isolating and tokenistic in its approach to women, without taking into account the existing gender power relations which impeded women's progress (Moser 2014). SOW called for a shift in focus to gender which would take into account the restrictive social relations and hierarchies.

Getting gender to be seen as an integral issue within research in IDS, however, was a struggle. Richard Jolly cites Kate Young as recalling that 'the work was treated as marginal to the central concerns of the majority of IDS Fellows' (Jolly 2008: 35). Interviewees we spoke to for this article related the struggle to get the MA Gender and Development - a cooperation between IDS and the University of Sussex, led by Ann Whitehead - into existence. Initial attempts to establish an MA in Gender and Development as a collaborative teaching programme between IDS and the University of Sussex were met with stiff opposition. It was several years before the first students enrolled for what in 1987 was the first UK MA in Gender and Development. Resources and readings from the conference and issues of the IDS Bulletin from 1978 and 1979 provided a valuable grounding in feminist theory and GAD debates for the students on this course.

The struggle to make gender visible at IDS is also evident from the experience of a former IDS Fellow, Naila Kabeer, who has been hugely influential in shaping the field of GAD. Kabeer arrived at the Institute 
in 1985 after these several years of collaboration by Young, Whitehead and others. Her research and consultancy work markedly strengthened the gender focus at IDS and led it in new and fruitful directions.

When Kabeer first came to IDS, as Whitehead observed in her introduction to Kabeer's 2013 inaugural lecture at the School of Oriental and African Studies (SOAS), University of London, 'the invisibility of gender and women within development studies was chronic, nowhere more so than at IDS despite the little enclave of gender work that had been fought for there' (Whitehead 2013). This is a significant point as in the late 1980s and through the 1990s, IDS was playing 'a crucial role in the evolution and application of theoretical ideas about development... [and] had some of the brightest and best development thinkers' (ibid.).

Kabeer's role in challenging the male bias in development studies is evident from her 1994 book, Reversed Realities, which 'contains incisive analysis on the ways in which economics was unable to address gender issues'. Further, it 'develops a distinctive array of gender relational conceptual tools and explores the development practice of a wide array of development actors' (Whitehead 2013).

One significant vehicle for disseminating IDS' gender analysis during this period is the three-month residential training course on 'Women, Men and Development' which Young established in 1984 and which Kabeer worked on in her first years at IDS. The course was aimed at intermediary-level government policymakers, women's organisations and activists among others, giving them the opportunity to share experience from the field and to learn from the theory. As Whitehead (2013) further points out, it led to 'a highly influential gender training framework... which showed practitioners at all levels how to analyse gender power within a structured framework of key social institutions'. The framework was subsequently used by Kabeer and other IDS colleagues for gender training within development institutions of all kinds, from the World Bank, to local non-governmental organisations (NGOs) and grass-roots feminist organisations. Conversely, however, an analysis by Poats and Russo (1989) found that it still had 'limited impact' on getting gender issues incorporated within the rest of IDS.

The struggles researchers faced in integrating a gender focus within research at IDS at this time has clear parallels with the global struggles faced by global feminists in getting women visibilised in development. The SOW collective successfully questioned development thinking on WID, played a convening catalyst role in establishing a network of feminist thinkers as well as laying the basis for subsequent more diverse gender research in IDS. Almost 60 participants took part in the innovative 1978 'Continuing Subordination of Women in the Development Process' conference -26 from the global South and 31 from the North, which was 'very important in establishing the field' (Whitehead pers. comm.). The residential training made long lasting connections to Southern partners, with, for example, Sri Lankan alumni taking part in the IDS 
40 round-table discussions in Colombo in 2006. ${ }^{3}$ Alumni from the MA Gender and Development have gone on to influence feminist thinking and policymaking in a whole range of roles. This period provided a strong basis for the future gender and sexuality work of IDS.

\section{Knowledge convening}

In thinking about IDS' convening role, it has not only been about bringing people together, but also about collating knowledge.

Indeed, Kate Hawkins notes that for the Sexuality and Development Programme, which we discuss later in this article, 'knowledge services had a lot to do with [sexuality] gaining currency in terms of power' (pers. comm.). One of the most important examples of this for IDS gender work is BRIDGE, a specialised GAD research and information service. BRIDGE was established in 1992 to provide background information for basing gender-related policy decisions on. The concept came about through a coordination between Rosalind Eyben who was then Chief Social Development Adviser at the Overseas Development Administration (ODA, later the Department for International Development (DFID)) and IDS Fellow Susan Joekes. Following four years of trying to get WID onto the ODA's agenda, Rosalind's staff were being inundated with requests for information that they couldn't respond to quickly. Thus the idea for BRIDGE was born. Managed by Sally Baden, it initially acted as a response unit for the requests being received by Development Assistance Committee members, providing studies on a range of issues relating to WID.

Subsequently, BRIDGE moved from a more reactive to a proactive model. In 2001 its Cutting Edge Programme was launched with a Cutting Edge Pack on the topic of Gender and Participation. The Cutting Edge Programme brings together examples of practice, lessons and recommendations from BRIDGE's partners and wider networks. The BRIDGE team identifies themes through conversations with their stakeholders and develops a pack for each which provides a map as to who is doing what and how. The spirit behind it is one of co-construction - an assemblage identifying with the IDS strength of convening. As Hazel Reeves, former BRIDGE manager notes, the Cutting Edge Packs '... developed into building a community of practice. With people working together to collect learning on an issue' (pers. comm.).

The 'politicising of knowledge' in terms of co-construction and promotion of hidden voices has been an important progressive step in development communications (Datta 2012). BRIDGE has advanced this not only in their sharing of knowledge from around the world via Siyanda and their shared development of the Cutting Edge Programme, but also through their multilingual work. The multilingual resource programme has brought a democracy of knowledge with it an opening out of the traditional routes of development knowledge.

There is an undeniable dominance of the English language in development. To counter such dominance and increase the visibility of 
research, case studies, good practice and experiences across languages are needed. Gender research and good practice that is conducted and disseminated in non-English countries is insufficiently represented or valued at global levels where the main language remains English, thus creating silos and missed opportunities. It also prevents English-speaking researchers and practitioners from benefiting from a wealth of very valuable studies and experiences carried out in non-English regions. For this reason, BRIDGE engages with a number of partners in nonEnglish-speaking regions so that those voices are heard and their multiple knowledges are integrated within the GAD discourse. BRIDGE works in collaboration with its partners to promote and generate knowledge on the gender dimensions of key development issues by facilitating the exchange of ideas and information, and by building learning in ways that integrate multiple knowledges expressed in different languages.

\section{Women's empowerment: critiquing norms}

BRIDGE's democracy of knowledge is echoed in the Pathways of Women's Empowerment programme's (Pathways) approach to research and communications. Pathways was a research and communications programme developed in response to DFID's call for a programme on women's empowerment in 2005. The 1990s through to the 2000s saw an increasing development industry preoccupation with women's empowerment, shaped particularly by the instrumentalist direction of Goal 3 of the Millennium Development Goals: 'Promote gender equality and empower women' (Cornwall, Harrison and Whitehead 2004). Women's empowerment had originally been 'a rallying cry' for Southern feminists in the early 1990s (Cornwall, Gideon and Wilson 2008a: 3). Conversations around how change happens within the Gender Working Group, an important cross-IDS group that worked together over the course of the 2000s on gender, fed into the development of Pathways. Anne-Marie Goetz, an IDS Fellow at this time, was a key participant in these conversations. Her work on gender and governance at IDS in the 1990s and early 2000s provided some of the underlying thinking to the Pathways approach (see, for instance, Goetz 1997). Pathways was convened at IDS with partners based in Latin America, the Middle East, South Asia and West Africa.

The early design of Pathways, led by Andrea Cornwall together with members of IDS' Gender Working Group, notably Anne-Marie Goetz, Naila Kabeer and Rosalind Eyben, was shaped by a critique of the normative framing of WID and research and publication practices that maintained the hegemony of the global North in shaping what counts as knowledge. Two international conferences held at IDS drew together leading figures in global debates on GAD. The first in 2003 on 'Gender Myths and Feminist Fables: Repositioning Gender in Development Policy and Practice' was co-organised by Andrea Cornwall, and Elizabeth Harrison and Ann Whitehead, University of Sussex, and explored how the appropriation of feminist language in development, such as the adoption of the term 'women's empowerment', had divested it of its nuances and meaning, reducing it to essentialisms which lost the 
complexity of women's lives. Although it was noted that at times reducing issues such as women's inequality to easily memorable slogans could have benefits in order to draw in attention and much needed resources, the stereotyping of women as victims in need of development's beneficence meant them losing identity and voice (Cornwall et al. 2004; Win 2004).

The second conference, in 2007, on 'Reclaiming Feminism: Gender and Neoliberalism', co-organised by Andrea Cornwall, Jasmine Gideon from Birkbeck, University of London and Kalpana Wilson from the London School of Economics and Political Science (LSE), critiqued the neoliberal development discourse engagement with empowerment (Cornwall et al. 2008a). Discussions at the conference focused on how neoliberalism had reproduced conservative notions of womanhood, straitjacketing women into a nurturing role within the family. These instrumentalist ideas cast women with the responsibility for ensuring economic growth - 'a weapon in the fight against poverty' (DFID 2007: 31 cited in Cornwall et al. 2008a).

In individualising women in this way and associating 'empowerment' with self-improvement, the collective and relational aspect of women's empowerment had been lost. Original conceptions of the term by Southern feminists referred to a collective challenging of power relations (Batliwala 1994). In this new language women's empowerment interventions became 'magic bullets' expediently bestowing empowerment - interventions such as women's quotas for parliamentary seats - neglecting to take into account context and restrictive ideologies which persist (Tadros 2011; Cornwall and Goetz 2005). In the words of Cecilia Sardenberg (convenor of the Pathways Latin America Hub) it was liberal rather than liberating empowerment (Sardenberg 2008), minimising the importance of women's organising which was a key focus of the Pathways programme. As Kate Young noted in 1979, 'only where women's organisations are strong and not merely an adjunct to the progressive political party, do such questions [on women's subordination] become a central part of the political debate and struggle around the priorities to be adopted in the planned development of society' (1979b: 4).

IDS played an important convening role in the development of these conference conversations in terms of bringing together leading feminist thinkers through networks and connections forged in the early years of the SOW collective. The fundamental design of Pathways based on feminist thinking in terms of a democracy of research and budget control, however, was the product of the strong partnership of feminist activists and academics from countries across Latin America, the Middle East, South Asia and West Africa. The programme held the joint decision-making of all voices to be a core value and placed an emphasis on publishing Southern feminist academics (Pathways 2011).

The use of creative communications in Pathways was strongly linked to its research and the ethos of challenging norms. Communications were used as a way of changing the conversation and bringing in new voices. 
This included the early adoption of digital storytelling methodology; film production which teamed researchers with film-makers to shed new perspectives on the research and to focus on the complexity of women's lives; and facilitating research participants to tell their own story through photography.

One particular example of this amplifying of marginalised voices is the film, Save Us From Saviours (www.saveusfromsaviours.net) which Pathways members worked on with the VAMP [Veshya Anyay Mukti Parishad] collective in India to put forward the perspective of sex workers and how they mobilised to claim their rights and support each other. As well as a way of challenging development myths and stereotypes such as the poor, powerless African woman (Win 2004; also see Cornwall, Harrison and Whitehead 2008b; Lewin 2010), incorporating visual and storytelling methodologies is a way of promoting empathy and understanding for an issue.

In talking about gender-based violence in conflict, Anne-Marie Goetz remarks:

The most powerful tool for changing hearts and minds is, first, direct exposure to women who have experienced violence and conflict, and second, clever media work that brings women's experience of conflict to life for policymakers... It is critical to expose policymakers to an alternative perspective, which is most effective when there is an emotional element. Policymakers have to feel differently in order to act differently (Goetz in Hudson 2014: 341-2).

Indeed, thinking back to the IDS Sexuality and Development Programme, for Kate Hawkins a critical moment in the work was a 2010 event held at DFID. The event featured ' 10 panels, one short quote and gripping photos illustrating the connections between people's material wellbeing and sexual rights' (pers. comm.). The visual aspect helps to make the connections more tangible.

\section{Visibilising sexuality}

Moving next to the theme of sexuality, which the sexual rights movements and queer theorists were engaging in from the late 1980s through the global HIV response, IDS joined the debates in the first decade of the 2000s by critiquing the development industry for not paying attention to pleasure and linking sex to death and disease.

As with gender as a broader issue in the early 1970s, work coming out of IDS argued that development had side-lined sexuality (Cornwall and Jolly 2006). In a landmark IDS Working Paper, which placed sexual minorities and/or dissidents in development, Andil Gosine (2005) argued that the 'reduction of sexual rights to reproduction (for women) and/or AIDS (for men)' (2005: 12) undermined the fact that sex can also be 'a pleasurable activity' (2005: 13). For Gosine, reconfiguring conversations about sex in development to focus on 'eroticism, recreation and pleasure' (2005: 13) could advance debates on and reveal new strategies for realising sexual rights. Through this critique - along with critiques from 
Susie Jolly, Andrea Cornwall and others - the heteronormative nature of development was challenged, with a 2006 IDS Bulletin showing 'why sexuality matters' (Cornwall and Jolly 2006).

Since the early 2000s when IDS was first engaging with issues of sexuality and development, the visibility of this nascent field has increased. Interviews with Susie Jolly, who first convened the Sexuality and Development Programme, reveal how this came about. When Jolly first arrived at IDS as a student in 2000, she organised a seminar series called 'Queering Development', which she explains 'opened the discussions in IDS' (pers. comm.). Getting from Jolly's 2000 seminar series to where IDS is now - moving beyond the 'straitjacket' of heteronormativity, opening up discussions on sexual rights beyond a narrow focus on health and getting recognition for the pleasure factor - was not easy due to assumptions that 'the development industry shouldn't be interfering with people's lives' (Jolly pers. comm.).

Yet the influence of a series of people and events led to the discourse being shaped in a more 'pleasurable' way, such as 'an advisory group which decided sexuality should be a topic' (Jolly pers. comm.) and funding, which Andrea Cornwall and Susie Jolly were able to secure from the Swedish International Development Cooperation Agency (Sida) and DFID 'to develop initial working papers, and to hold the first Sexuality and Development workshop, which gave rise to the 2006 IDS Bulletin 'Sexuality Matters' (pers. comm.). Indeed, for Kate Hawkins who convened the Sexuality and Development Programme after Susie Jolly left in 2010 - 'progressive donors' such as Sida have been critical to sexuality's increased visibility within IDS as this 'laid the foundation for the direction of work we were going to do' (pers. comm.). This in turn has contributed to wider discussions on the larger-scale struggle to take sexuality seriously in development work. Debates have explored issues such as redressing the marginalisation of sexuality in development policies and programmes, and the importance of recognising the significance of sexual wellbeing for all dimensions of development.

Building on this momentum, Jolly cites another major turning point in the work on sexuality: the workshop, 'Development's Marginalisation of Sexuality' held at IDS in 2005. Described as 'a joined up sexual rights movement' (Jolly pers. comm.), the workshop 'brought together people from the global South working on a whole range of sexuality issues - researchers, activists, policymakers, donors, government, national organisations'. As detailed in a report drawing on discussions from the workshop, the conversations - which centred on placing the issue of sexual rights on the development agenda - were also taking place at IDS, which 'represents, to many, the very heart of the development mainstream' (Cornwall 2006: 284) and was exciting:

There was a tangible feeling of exhilaration at being able to bring issues of sexuality into an arena that has remained so impervious to its significance. To see the corridors of IDS lined with the provocative 
art of Peruvian travesti activist Giuseppe Campuzano, and decked with brightly coloured declarations of sexual rights, was something in itself. To engage people who have led development thinking on poverty and power, like Robert Chambers, in debate on the connections between sexuality and development was something again (ibid.).

This further indicates the strength of IDS as a convenor to create a space which brings various actors together to discuss the centrality of sexuality in development discourse.

It is vital to mention here, from Jolly, Cornwall and Hawkins' point of view, that similar to getting gender on the agenda in the late 1970s, was the crucial role IDS MA and MPhil gender students have also played. Hawkins pointed out that we should 'give credit where it is due' as 'students at IDS are very progressive and a helpful constituency in thinking some of these issues' (pers. comm.). For Jolly, 'it was students' that were one of the most interested groups - in addition to scholars, such as Andrea Cornwall and Alan Sinfield, who led the Sexual Dissidence programme at the University of Sussex. Correspondence with Cornwall echoes this:

When I arrived at IDS in 1998, there was no work on sexuality at all: it was with my students on the MPhil - Andil Gosine, Susie Jolly, Divya Bajpai - that the first contributions to the debate on sexuality and development were made. I invited Andil to write what became our first sexuality and development working paper, and Susie and I worked together to develop a proposal for a programme that secured funding from DFID in 2007, with which we were able to launch the Sexuality and Development Programme at IDS. We also integrated sexuality into the Pathways RPC [Research Programme Consortium], despite internal and external opposition (Cornwall pers. comm.).

Since then IDS has seen its work in this area expand with the Sexuality, Poverty and Law (SPL) programme that launched in 2012. Building on the earlier work of Jolly, Cornwall and others, such as tracing the linkages between inequality, poverty and sex, the SPL programme continued to take this agenda forward by generating robust evidence on the link between poverty and sexuality. Additionally, the earlier work on sexuality and development in the Institute created a powerful network of partners around the world who, together, brought sexuality into focus in the areas of law and development policy and practice. The SPL programme built on that through the co-creation of innovative tools based on the existing evidence to equip activists, civil society organisations and national and international policymakers to create equitable and inclusive societies.

As Stephen Wood, Research Officer on the SPL programme, writes in a blog post, it has 'from its inception [aspired] to redress the historic paucity of evidence to show that sexual minorities suffer a double-bind of prejudice and exclusion from economic security' (Wood 2014). This can be seen in a number of outputs that it has produced. Through a 
Sexuality and Social Justice Toolkit, ${ }^{4}$ five policy audits, seven legal case studies and nine poverty case studies (among others), the programme has worked with a network of country-partners to reveal empirical evidence that demonstrates - to national governments, donors and civil society organisations - that discrimination has a cost, not only for individual wellbeing, but for national prosperity. To this end, in addition to country-level output, the SPL programme has also been working with donors, international civil society organisations and academic institutes to lobby for international agencies to integrate (among other points) sexuality-sensitive indicators into the data that is collected and reported through development programmes at a country level.

Now, decades later, through its work on sexuality, IDS has generated over 40 reports and briefs that trace the socioeconomic impacts of discriminatory policies and laws on the lives of people marginalised because of their gender identity and sexuality. This body of work calls attention to the socioeconomic implications of legal and policy marginalisation. This is particularly crucial as we move into the next development era under the Sustainable Development Goals. Moreover, as Elizabeth Mills, the convenor of the SPL programme since 2013, writes, the evolution of the GAD field has paved the way for IDS' work on sexuality in two main respects:

First, the evolution of evidence on inequality informed a corresponding evolution in development policy approaches, showing the importance of policy change that is agile, able to take up and respond to robust evidence. As we build up an increasingly robust evidence base on the links between poverty and sexuality at IDS, we see a real commitment within the $\mathrm{UK}$, and in other countries around the world, to ensure that development practice takes up and responds to the challenges posed by these emerging findings.

Second, the evolution the GAD field was driven by researchers, policymakers and activists who insisted on thinking at the edge of the mainstream; people like Naila Kabeer, who pioneered novel ways to quantify household-level inequality. The field was pushed even further by people like Andrea Cornwall, Susie Jolly and Kate Hawkins, who started to challenge the very notion of gender as a binary and as about heterosexuality. In doing so, they opened a new era of work in the field of development, akin to that era -40 years previously, when gender entered development (pers. comm.).

\section{Men: what have they got to do with it?}

A final example of IDS' convening and provocative questioning can be seen in its men and masculinities work, which was initiated by Andrea Cornwall in 2000 - building on the original GAD intention to be relational and structural - before being jointly convened by Cornwall and Jerker Edström from 2007 and then solely by Edström until today. In that time IDS research has contributed significantly to the field of knowledge on engaging men and boys in gender equality initiatives, 
initially in contexts of addressing HIV/AIDS and tackling gender-based violence to the most recent work on 'Engendering Men: Evidence on Routes to Gender Equality' (EMERGE). ${ }^{5}$

This stream of work, over a period of more than a decade, has also seen the publication of a number of influential texts, including Men and Development: Politicising Masculinities (Cornwall, Edström and Greig 2011) and three issues of the IDS Bulletin - 'Men, Masculinities and Development' (2000), edited by Andrea Cornwall and Sarah White; 'Undressing Patriarchy' (2014), edited by Jerker Edström, Abhijit Das and Chris Dolan; and the virtual IDS Bulletin, ${ }^{6}$ 'Challenging Patriarchy: Unsettling Men and Masculinities', edited by Andrea Cornwall and Jerker Edström. These issues of the IDS Bulletin helped in shaping the discourse around the issues by, for instance, bringing attention to the structural implications of male privilege (Cornwall and White 2000) and exploring the shifting roles of men and masculinities and their engagement with feminism (Edström et al. 2014). The recognition of the importance of including men and not just women in gender research for IDS goes back to the original SOW collective and their critique of the WID narrative.

Since 2007 IDS, along with crucial partners in the field, has been supporting 'fine-grained research, innovative programming and critical self-reflection' (Shahrokh et al. 2015: 4) within the field of engaging men and boys in work for gender justice. That same year, IDS convened researchers, activists and donors to chart a course for 'Politicising Masculinities: Beyond the Personal' (Esplen and Greig 2008) in a Sida-supported international symposium in Dakar, Senegal to challenge the ways in which masculinities and work with men and boys had been taken up in policy and in discourse (Hawkins et al. 2013).

Organised, led and facilitated by IDS researchers Andrea Cornwall and Jerker Edström, and Alan Greig, an independent consultant, Edström explains in the workshop report (Esplen and Greig 2008: 6) what motivated him to organise the symposium:

When I joined IDS last year [2006], I soon engaged with Andrea Cornwall and others on this topic [HIV, gender and sexuality]. We started discussions about how the AIDS world was reverting back to more medicalised and simplistic service-provision frameworks, de-sexualising and often 'mis-gendering' HIV under the weight of increasingly right-wing hegemonic masculine US power brokers, backed up with massive resources for a global response to AIDS. We also lamented the fact (or perception) that 'gender' is no longer really offering us many exciting or helpful conceptual tools, but rather seems to be inadvertently stuck in reconstructing or reinforcing essentialist and 'heteronormative' gender binaries.

Certainly, a lot has been learned about HIV from work with men, as well as from work with women - particularly sex workers. But the issues are not being heard loud enough and some of the lessons 
are not being considered critically. So we wanted to engage more directly with those most engaged with the issues and try to make a contribution to advancing our collective thinking. We thought the best way to start would be to call a big meeting of some of the best people we knew from around the world, who are dealing with these issues in their work and lives.

The Dakar symposium, as noted in a recent Stories of Influence report, brought up the important need in the field of GAD to 'engage men in addressing the structural determinants and institutional manifestations of gender injustice' (Shahrokh et al. 2015: 4). During the discussions participants challenged the idea of the gender binary, explored the multiple contexts that give rise to gender inequalities and tried to find ways of stimulating creative alliances between like-minded social movements (Hawkins et al. 2013). The symposium led to three outputs: (1) an event at the AWID Forum in Cape Town in 2008, organised by Andrea Cornwall, Alan Greig and Jerker Edström, 'Women's Empowerment: What Do Men Have to Do With It?', which was one of the only events at the forum to address the issue of masculinities, and was voted one of the top ten sessions of the forum (AWID 2009); (2) a meeting, 'Heteronormativity: Untying the Straight-jacket of Development', which took place in Cape Town in 2010; and (3) a book - Men and Development: Politicising Masculinities (Cornwall et al. 2011).

In an effort to take this agenda forward, Edström also undertook work with civil society partners to mobilise men to challenge sexual and gender-based violence (SGBV) within institutional settings. This saw the development of the 'mobilising men to challenge SGBV in institutional settings' project in 2010 (Greig with Edström 2012). Partnering with civil society organisations in India, Kenya and Uganda, this project identified, recruited, trained and supported teams of male activists to work with women in developing campaigns to challenge and change the policies and cultures of specific institutional settings that condone or even fuel SGBV. This project, supported by the UN Population Fund, was sustained and strengthened within the Gender, Power and Sexuality (GPS) Programme, constituting the work of its men and masculinities stream, as well as the Empowerment of Women and Girls' programme with the work on collective action and SGBV which continue to look at the roles of men in the process of achieving gender equality.

Six years after the Dakar symposium, the 'Undressing Patriarchy: Redressing Inequalities' symposium was held in 2013 in Hove (Brighton, UK). Edström, one of the symposium organisers, provided an introduction as to why he felt it was important to 'undress patriarchy', to be able to 'explore the patriarchal features of different systems of power... to revitalise and advance conversations and thinking about gender inequality in relation to patriarchy and other structures of power [and] to make patriarchy - which is certainly problematic, complex and oppressive - more comprehensible and visible' (Hawkins et al. 2013: 7). It can then be seen that from 'Politicising Masculinities' in 
2007 in Dakar to 'Undressing Patriarchy' in 2013 in Hove, there have been a number of symposia convened by IDS that have argued for the important need to engage men in efforts for gender justice.

In general, IDS' work in this area has sought to challenge the 'simplistic binary of "women" and "men", such as stereotypes of women as passive/victim and men as active/perpetrator. It has, instead, sought to 'understand and undertake gender justice work in relation to people's complex experiences of power and oppression' (Shahrokh et al. 2015: 4) and to re-politicise 'gender in development'.

\section{Conclusion}

In reflecting back over the 50 years of IDS and with the particular focus on over 40 years of gender and sexuality research, what has come out strongly in the interviews we conducted is the fusion of creative people and spaces which permitted a healthy questioning of the development discourse. People like the first IDS academics to work on gender issues such as Kate Young and Naila Kabeer who showed persistence in advancing the cause of gender research, despite internal IDS struggles which mirrored external global struggles, the MA Gender students who have maintained a progressive activism in their approach to studies at IDS, those working on communications and knowledge who have experimented in creativity and promoted equality of voice, and the many networks and partners who have challenged and influenced ways of thinking. Spaces, which have been created due to IDS' global convenorship, have been afforded in ways such as progressive funders, the working with people outside academia who could bring a different perspective, and the many conferences and meetings which brought dynamic groups of people together.

In this time, IDS has played a role in the conceptual shift from WID towards a GAD approach, while also critically bringing sexuality and masculinities into gender theory, research and practice. It has come a long way since the early days when gender was a very marginalised topic. Issues which were invisible such as sexuality and pleasure have become visibilised and those not previously on the agenda such as masculinities have moved to the agenda. In 2014, IDS took a new step in underlining the importance of gender and sexuality research by forming the Gender and Sexuality Cluster.

Work continues to be provocative, creative and progressive, such as the Love Matters Music Awards which encouraged young Kenyan students to produce music on topics of love and sexuality which mattered to them (IDS 2015); the Who Cares animation, which highlights the key issues of women's unpaid care work and provides practical solutions to address this (IDS 2013); and the Sex Work Law Map which provides an overview of legal frameworks on sex work around the world.

Now almost 40 years since the appointment of IDS' first Gender Fellow, the Institute continues to play a significant role in creating those necessary 
spaces - in research, teaching, knowledge and communication - needed to politicise the dialogues and reveal normative assumptions around gender and sexuality in development debates. Debates, such as the relationship between sexual pleasure and wellbeing, that are taken for granted.

Looking forward, there are certainly some challenging questions that could shape the focus on gender and sexuality research, teaching, knowledge and communication at IDS. What do shifts in development, such as increased global migration, urbanisation, new technologies, resurgent fundamentalisms and so on mean for gender and sexuality research? We have revealed in this article how the ways in which previous and current work and researchers at IDS have sought to put gender and sexuality on the development agenda through research, dialogue and communication. Reflecting on the history of IDS is significant for the generation of research and knowledge that continues to challenge gender and sexuality 'myths' and stereotypes, while contributing to transformative policy, practice and activism in the future.

\section{Notes}

* The authors would like to thank Andrea Cornwall, Elizabeth Harrison, Kate Hawkins, Susie Jolly, Hazel Reeves and Ann Whitehead for agreeing to be interviewed for this article and for kindly giving up their time for the interviews. We would also like to thank Paola Brambilla, Andrea Cornwall, Jerker Edström, Elizabeth Mills and Ann Whitehead for their helpful comments on previous drafts. Finally, we would like to acknowledge the work of all the many researchers on gender and sexuality at IDS over the years. For reasons of space we have had to be selective about the work we touched upon, but we recognise that there is a greater body of work which combines to create the IDS gender and sexuality research story. All errors and omissions are the responsibility of the authors.

1 BRIDGE is a specialised gender and development research and information service based at IDS (www.bridge.ids.ac.uk).

2 The term 'heteronormativity' grew out of 'queer theory' and is the assumption that heterosexuality is the norm and any other form of sexual desire, expression or relationship is 'abnormal' or 'wrong'. It is underpinned by the assumption that there are only two sexes, men and women, which exist in a binary. See www.eldis.org/go/ topics/resource-guides/gender/key-issues/heteronormativity\#. VsHCyvmLTIU (accessed 15 February 2016).

3 One of a series of 46 round-table events convened for the Institute of Development Studies' 40th Anniversary.

4 Launched in 2014, it is 'an interactive platform that synthesises much of the reflexive, collaborative learning undertaken with partners so far in the Programme' (Wood 2014).

5 See http://menandboys.ids.ac.uk.

6 See www.ids.ac.uk/publication/challenging-patriarchy-unsettlingmen-and-masculinities. 


\section{References}

AWID (2009) Forum 08 in Review: The Power of Movements, Toronto: Association for Women's Rights in Development

Batliwala, S. (1994) 'The Meaning of Women's Empowerment: New Concepts from Action', in G. Sen, A. Germain and L.C. Chen (eds), Population Policies Reconsidered: Health, Empowerment and Rights, Cambridge MA: Harvard University Press

Berger, I. (2007) Decolonising Women's Activism: Africa in the Transformation of International Women's Movements, http://wasi.alexanderstreet. com/help/view/decolonizing_womens_activism_africa_in_the_ transformation_of_international_womens_movements (accessed 15 February 2016)

Boserup, E. (1970) Women's Role in Economic Development, London: Allen \& Unwin

Cornwall, A. (2006) 'Development's Marginalisation of Sexuality: Report of an IDS Workshop', Gender and Development 14.2: 273-89

Cornwall, A. and Goetz, A.M. (2005) 'Democratizing Democracy: Feminist Perspectives', Democratization 12.5: 783-800

Cornwall, A. and Jolly, S. (2006) 'Introduction: Sexuality Matters', IDS Bulletin 37.5: 1-11, http://bulletin.ids.ac.uk/idsbo/article/ view/910 (accessed 31 March 2016)

Cornwall, A. and White, S.C. (2000) 'Men, Masculinities and Development: Politics, Policies and Practice', IDS Bulletin 31.2, http://bulletin.ids.ac.uk/idsbo/issue/view/92 (accessed 31 March 2016)

Cornwall, A.; Edström, J. and Greig, A. (2011) Men and Development: Politicising Masculinities, London: Zed Books

Cornwall, A.; Gideon, J. and Wilson, K. (2008a) 'Introduction: Reclaiming Feminism: Gender and Neoliberalism', IDS Bulletin 39.6: 1-9, http://bulletin.ids.ac.uk/idsbo/article/view/710 (accessed 31 March 2016)

Cornwall, A.; Harrison, E. and Whitehead, A. (eds) (2008b) Gender Myths and Feminist Fables: The Struggle for Interpretative Power in Gender and Development, Oxford: Blackwell

Cornwall, A.; Harrison, E. and Whitehead, A. (eds) (2007) Feminisms in Development: Contradictions, Contestations and Challenges, London: Zed Books Cornwall, A.; Harrison, E. and Whitehead, A. (2004) 'Introduction: Repositioning Feminisms in Gender and Development', IDS Bulletin 35.4: 1-10, http://bulletin.ids.ac.uk/idsbo/article/view/1056 (accessed 31 March 2016)

Datta, A. (2012) 'Deliberation, Dialogue and Debate: Why Researchers Need to Engage with Others to Address Complex Issues', IDS Bulletin 43.5: 9-16, http://bulletin.ids.ac.uk/idsbo/article/view/276 (accessed 31 March 2016)

DFID (2007) Gender Equality at the Heart of Development, London: Department for International Development

Edström, J.; Das, A. and Dolan, C. (2014) 'Undressing Patriarchy: Men and Structural Violence', IDS Bulletin 45.1, http://bulletin.ids.ac.uk/ idsbo/article/view/199 (accessed 31 March 2016) 
Esplen, E. and Greig, A. (2008) Politicising Masculinities: Beyond the Personal, Report of an International Symposium 15-18 October 2007, Dakar, Senegal, Brighton: IDS

Goetz, A.M. (ed.) (1997) Getting Institutions Right for Women in Development, London: Zed Books

Gosine, A. (2005) Sex for Pleasure, Rights to Participation, and Alternatives to AIDS: Placing Sexual Minorities and/or Dissidents in Development, IDS Working Paper 228, Brighton: IDS

Greig, A. with Edström, J. (2012) Mobilising Men in Practice: Challenging Sexual and Gender-Based Violence in Institutional Settings - Tools, Stories, Lessons, Practice Guide, Brighton: IDS

Hawkins, K.; Bisht Preetha K.; Maldonado Pacheco, A.; NesbittAhmed, C. and Edström, J. (2013) Undressing Patriarchy: Redressing Inequalities, Report of an International Symposium 9-12 September, Brighton: IDS

Hudson, N.F. (2014) 'Too Much that Can't be Said: Anne Marie Goetz in Conversation with Natalie Florea Hudson', International Feminist Politics 16.2: 336-46

IDS (2015) Love Matters Music Award 2015, www.ids.ac.uk/news/lovematters-music-award-2015 (accessed 27 January 2015)

IDS (2013) Who Cares: Unpaid Care Work, Poverty and Women's/Girls' Human Rights, animation, www.youtube.com/watch?v=VVW858gQHoE (accessed 28 January 2015)

Jolly, R. (2008) A Short History of IDS: A Personal Reflection, IDS Discussion Paper 388, Brighton: IDS, www.ids.ac.uk/publication/a-short-historyof-ids-a-personal-reflection (accessed 11 March 2016)

Kabeer, N. (1994) Reversed Realities: Gender Hierarchies in Development Thought, London: Verso

Lewin, T. (2010) 'Communicating Empowerment: Countering the Cardboard Woman', Development 53.2: 222-6

Moser, C. (2014) Gender Planning and Development: Revisiting, Deconstructing and Reflecting, DPU60 Working Paper Series: Reflections 165/60, London: Development Planning Unit

Pathways (2011) Empowerment: A fourney not a Destination, Brighton: Pathways of Women's Empowerment

Poats, S.V. and Russo, S.L. (1989) Training in WID/Gender Analysis in Agricultural Development: A Review of Experiences and Lessons Learned, prepared for the Women in Agricultural Production and Rural Development Service of the Food and Agricultural Organization, November, Gainesville FL: Tropical Research and Development Inc.

Rai, S.M. and Waylen, G. (2013) New Frontiers in Feminist Political Economy, London: Routledge

Sardenberg, C. (2008) 'Liberal vs Liberating Empowerment: A Latin American Feminist Perspective on Conceptualising Women's Empowerment', IDS Bulletin 39.6: 18-27, http://bulletin.ids.ac.uk/ idsbo/article/view/712 (accessed 31 March 2016)

Shahrokh, T. with Edström, J.; Greig, A.; Das, A.; Dolan, C.; Ongwetch, D.O.; Otieno, P.E. and Singh, S.K. (2015) From Dakar to Delhi: Influencing Policy Discourse on Men and Masculinities, Brighton: 
IDS, Centre for Health and Social Justice (CHSJ), Men for Gender Equality Now (MEGEN) and Refugee Law Project (RLP)

Tadros, M. (2011) 'Women Engaging Politically: Beyond Magic Bullets and Motorways', Pathways Policy Paper, Brighton: Pathways of Women's Empowerment

Young, K. (ed.) (1979a) 'The Continuing Subordination of Women in the Development Process', IDS Bulletin 10.3

Young, K. (1979b) 'Editorial', IDS Bulletin 10.3: 1-4

Whitehead, A. (2013) 'Introduction', to Naila Kabeer's Inaugural SOAS Lecture on 'Reflections on Researching Women's Empowerment - Journeys, Maps and Signposts', www.soas.ac.uk/about/events/ inaugurals/24jan2013-prof-naila-kabeer-reflections-on-researchingwomens-empowerment---journeys-maps-and-signpo.html (accessed 30 March 2016)

Win, E.J. (2004) 'Not Very Poor, Powerless or Pregnant: The African Woman Forgotten by Development', IDS Bulletin 35.4: 61-4, http://bulletin.ids.ac.uk/idsbo/article/view/1063 (accessed 31 March 2016)

Wood, S. (2014) 'Bridging the Gap: Strengthening the Sexuality and Poverty Evidence Base', IDS Participation, Power and Social Change Blog, https://participationpower.wordpress.com/tag/sexuality-and-socialjustice-toolkit/ (accessed 28 January 2015) 


\title{
The Evolution of Ethnicity Theory: Intersectionality, Geopolitics and Development
}

\author{
Naysan Adlparvar and Mariz Tadros
}

\begin{abstract}
Ethnicity has become prominent in popular and scholarly thinking over the last 50 years. In the late 1960 s a few key works stimulated the growth of a complex body of literature, now defined by four main theoretical approaches. New insights are also emerging. Chief among these is the importance of integrating intersectionality into ethnicity theory. The Institute of Development Studies (IDS) has also made important contributions to this literature and its application to development studies.
\end{abstract}

This article identifies three new frontiers in the study of ethnicity. First, theoretical effort is required to unpack how ethnicity intersects with other forms of identity. Second, as demonstrated by IDS' contributions, further research is required on the impacts of ethnicity upon development and vice versa. And, finally, the geopolitical landscape emerging since $9 / 11$ has stimulated major shifts in conceptions of ethnicity. These shifts and the resulting new framings of identity (ethnic and otherwise) beg investigation.

\section{Introduction}

Ethnicity is a hotly disputed concept. Since it emerged as an important form of collective identity in the 1960s, it has been appropriated by all kinds of people for all kinds of purposes. From political mobilisation that uses the necessity of ethnic homogeneity as the basis for expelling populations of different racial backgrounds, to the conflation of ethnicity with religion (as when people assume Muslims are an ethnic category), and the reduction of complex geostrategic and historic conflicts to 'ethnic strife'.

Thinking on ethnicity continues to be deeply shaped by and shape geopolitics. The events of $9 / 11$ have ushered in new framings of identity and emergent patterns of sociopolitical organisation. Sectarian violence is witnessed in Syria, Afghanistan and Iraq. The rise of the so-called Islamic State has furthered anti-Arab (and anti-Islamic) sentiment. The large-scale displacements of refugees across West 
Asia, the Middle East and into Europe have brought large numbers of people with different ethnicities, religions and nationalities into close proximity. Right-wing political parties in Europe and North America are resurgent, organising around imagined common histories and ethnic identities that demonise the other.

Ethnicity is also hotly debated in academia. Two key works published in the late 1960s challenged conventional academic thought regarding ethnic identity. This triggered the growth of a large and complex body of theory marked by diverging opinion. Opposing theoretical standpoints frame the literature, numerous debates punctuate it, and critiques of ethnicity are abundant. New insights, emerging from postmodernist critiques, are set to define new frontiers of research on ethnicity. Chief among these insights is the growing importance of intersectionality.

Section 2 of this article summarises this scholarly thinking on ethnicity. Section 3 is more specific in its analysis and investigates the contributions that the Institute of Development Studies (IDS) has made to ethnicity theory and its application in the field of development studies. Drawing on the preceding analysis, the final section of the article suggests new frontiers of research.

\section{The evolution of ethnicity theory: ${ }^{1}$ ethnic identity and intersectionality}

There are four main theoretical approaches that underpin the study of ethnicity. These are primordialism, instrumentalism, materialism and constructionism. The evolution of these approaches is closely linked to the development of theories underpinning thought in the social sciences: from cultural evolutionism, through structural functionalism, to conflict theories, and postmodernism (Wan and Vanderwerf 2009). A number of key debates run through these four areas of the literature. They include, among others, how to integrate the social and psychological dimensions of ethnicity, the importance attached to the cultural 'content' of ethnic identity, and the relationship between the state and ethnicity.

\subsection{The primordialist approach to ethnicity}

Up until the 1970s, and in some cases even later, primordialist accounts of ethnicity were common. Classic primordialist accounts generally view ethnic identity as innate, fixed and permanent. They claim each individual is born into an ethnic group or 'tribe' - the term commonly used up until the 1970s - perceived as a culturally defined unit. This led to tribes and later ethnic groups being classified by aspects of their material culture in addition to biological and territorial features. Primordialist accounts imply that ethnic identity serves a fundamental human need for belonging and meaning.

The primordial approach also suggests - in what is more commonly known as the 'ancient hatreds' argument - that the fundamental cultural differences and divergent values between ethnic groups inevitably results in a 'clash of cultures' and the emergence of ethnic violence. 


\subsection{The instrumentalist approach to ethnicity}

Two main contributions initiated the challenge to the classic primordialist approach. In his 1969 seminal essay, Barth (1998) challenged the primordialist belief that ethnic groups were distinct bounded units with innate cultural characteristics. Rather than focusing on the cultural 'content' of ethnic groups he adopted a subjectivist standpoint, suggesting that individuals selectively emphasise those forms of cultural differentiation that are important to them. He contends that the maintenance of ethnic boundaries occurs through interaction of 'us' and 'them' across a group boundary. Moreover, the cultural features that are drawn upon in this interaction are not fixed; they are situationally defined. In this way Barth emphasised the relational, interactional and situational nature of ethnicity.

The second group of contributors to challenge primordialist theories were members of the 'Manchester School'. These anthropologists analysed the relationship between black tribes and white colonialists in the African Copperbelt from the 1950s to the late 1970s. A key study from the Manchester School was Abner Cohen's (1969) thesis on the instrumentality of ethnic affiliation. Cohen's research on the Hausa and Yoruba tribes in Nigeria suggested that the principal function of ethnicity was informal political organisation. He argued that political elites in some cases create but also use and exploit 'primordial' symbols to gain the allegiance of potential followers.

Cohen's analysis also laid the foundation for instrumentalist contributions to the study of ethnic conflict. They posit that elites agitate ethnic tensions and, in some cases, intentionally provoke ethnic violence as a method to seize power, protect their existing authority, or defend against group threats (Fearon and Laitin 2000; Kaufmann 2005). These claims began a long running debate in the literature regarding the ways that the ethnic allegiance of the masses can be exploited, often for political ends, by elites.

The scholarly works of Barth and the Manchester School brought about a fundamental shift in the theoretical foundation of anthropology. Their research was central to critiques of structural functionalism, driving a shift in anthropology from the analysis of tribe as a unit of social structure to ethnicity as a process of social organisation (Jenkins 2008).

This was, however, not the only shift taking place in anthropology throughout the 1960s. Anthropology also passed through an intense phase of self-criticism following a growing awareness of its complicity in aiding and benefiting from colonialism (Davies 2008). Ethnographers had, for example, contributed to the reification of tribes in colonial states. This critique led to a preoccupation with reflexivity in anthropology, but also the emergence of a trend of critical reflection to avoid the reification of ethnic groups in the anthropological literature (ibid.).

Nathan Glazer and Daniel Moynihan (1975) also made a significant contribution to the instrumentalist approach of ethnicity. They framed 
their discussion of ethnicity in relation to the state. Crucially, Glazer and Moynihan argue that ethnicity has a 'strategic efficacy' in making claims upon the modern state. They claim that this is the result of state officials appeasing blocs of voters, who mobilise around constitutional commitments to 'collective rights'.

\subsection{The materialist approach to ethnicity}

Materialist approaches to ethnicity are relatively underdeveloped in the literature. 'Crude' Marxist theories, including the work of Michael Hechter (1978), view ethnicity as an epiphenomenon, or a result, of class relations. These crude Marxist theories also suggest that violence between ethnically aligned groups is the result of economic inequalities and elite exploitation.

The claims of crude Marxists received heavy empirical criticism from a wide range of scholars. It is now generally acknowledged that ethnicity is not a product of class relations and that there is no one-to-one relationship between the two categories (Eriksen 2002).

\subsection{The constructionist approach to ethnicity}

At the heart of the constructionist approach, as with its instrumentalist predecessor, is the belief that ethnicity is socially constructed. However, unlike the earlier instrumentalist conception, ethnicity is 'constructed', and done so continuously through social interaction, by both elites and ordinary people. The constructionist approach initiated a shift of focus in the literature, from what ethnicity is to how it is constructed.

Constructionist theory can largely be divided into three subsets of literature based upon the manner in which the construction of ethnicity is characterised. ${ }^{2}$ They are differentiated based upon whether individuals, discursive formations or broad structural forces are the chief agent in the construction of ethnicity.

Individuals as agents of social construction: The first subset of constructionist literature is mainly based on an expansion of earlier theories regarding the instrumental approach to ethnicity. Yet this newer strand of theory recognises the agency of ordinary people in addition to that of elites. With regard to the role of ordinary people, this body of literature sees ethnicity created and recreated through the everyday actions of individuals, who perceiving themselves as associated with a certain ethnic identity act to confirm, contest or propagate that identity (Fearon and Laitin 2000).

In discussions of ethnic conflict, the majority of constructionist literature focuses on the role of individuals - primarily of elites but also of ordinary people - in instigating violence. Constructionist theories, building on instrumentalist thought, account for the way ordinary individuals contribute to ethnic conflict. It is suggested that marginalised members of ethnic groups contest existing ethnic identities, thereby constructing new ones. This, in turn, can result in retaliatory violence from those elites who benefited from the previous form of ethnic identity (ibid.). Alternatively, marginal ethnic group members may 
employ violence aimed at other ethnic groups. This is carried out to gain increasing acceptance from established members of their own ethnic group (ibid.).

Discursive formations as agents of social construction: The second set of constructionist theory states that discursive formations, or cultural systems, intrinsically result in the construction of ethnic difference. Yet, such arguments have received criticism. They border on primordialism, as they portray culture as an unchanging force central to the construction of ethnicity (ibid.).

With regard to ethnic conflict, this body of constructionist literature focuses on the capacity of discourse to predispose members of one ethnic group to view members of another as natural targets of violence. While such theories of ethnicity are generally critiqued for adopting a primordialist approach, the construction-by-discourse view of ethnic conflict is widely critiqued for not being able to account for the wide variety in, and variance of, ethnic violence across the globe (ibid.).

\section{Broad structural forces as agents of social construction: The} final subgroup of constructionist theory, which is by far the largest, is preoccupied with the role of broad social, political and economic forces in the construction of ethnicity. Many of the major works linked to this subset of constructionist literature are preoccupied with processes of ethnogenesis, or the process leading to the emergence of ethnicity. Ethnogenesis is often linked to colonialism, globalisation, modernity, nationalism and the formation of the 'nation state' (Eriksen 2002).

When theorising ethnic conflict, this subgroup of constructionist literature argues that broad structural forces, for example, modernisation can lead to ethnic conflict. Although lacking a general explanation of how ethnic conflict breaks out, constructionist literature argues that modernisation leads to 'converging aspirations', thereby explaining why ethnic violence occurs.

\subsection{Postmodern critiques of ethnicity}

A number of critiques have been levelled at ethnicity theory since the rise of postmodernism in the 1980s. These critiques are of two main types. On the one hand, there are those scholars who call for a 'rethinking' of ethnicity (Jenkins 2008). Greater conceptual and analytical clarity is called for. On the other hand, some scholars argue for the outright abandonment of ethnicity (Carter and Fenton 2009). Critics point out how the tendency to use ethnicity as a catch-all concept for many varieties of group identity results in a loss of analytical depth. Ethnicity, it is argued, is therefore everything and nothing.

These critiques stem from the all-embracing usage of ethnicity in social analysis, which has led to what a number of scholars argue is an overethnicised interpretation of social reality (Comaroff and Comaroff 1992). In part, this critical perspective on ethnicity has emerged as postmodernist thought has complicated the conceptualisation of identity. 
A decentring of identity has been witnessed in the social sciences, with the idea of identity being innate and persistent being systematically challenged. Contemporary studies of identity are increasingly pointing to its multi-faceted and fragmented nature (Wetherell 2010).

One body of scholarship that is being taken up to respond to this critique is the literature on intersectionality. Kimberlé Crenshaw (1989) is credited with conceiving of the concept. Intersectionality emerged from critical race theory, drawn from the perspective of non-White feminist critiques framed by Afro-Americans in the United States dating back to the 1970s (Combahee River Collective 1977). At its core, intersectionality theory 'stresses that systems of power (e.g. race, gender, class, sexuality, ability, age, country of origin, citizenship status) cannot be understood in isolation from one another' (Collins and Chepp 2013: 61). Intersectionality, therefore, calls for a profound shift in the scope of analysis regarding ethnicity: a shift from the study of ethnic identity to the study of identities and their interrelationship.

\section{IDS' contribution: ethnic identity and development}

The preceding section provided a general overview of the large and complex literature on ethnicity theory. The following section is more specific. It locates the contributions made by IDS to research on ethnicity theory and its application to the field of development studies.

IDS' contributions can be categorised under six broad areas of inquiry, ${ }^{3}$ including: (1) ethnic identity and development policy; (2) citizenship and ethnicity; (3) ethnicity and violence; (4) health and sexuality issues of indigenous and minority groups; (5) ethnicity and volunteering; and (6) ethnicity, development and interethnic relations.

\subsection{Ethnicity and development policy}

The work of Bob Baulch, Hung Pham and Barry Reilly (2012) links ethnic identity to development policy. They investigate the gap in per capita expenditures between majority and minority ethnic groups in rural Vietnam. The period under research fell within the Doi Moi, or economic renovation, which resulted in large-scale poverty reduction. Yet, their findings indicate that during this period the real expenditure gap between rural Kinh and Chinese-headed households and those headed by ethnic minorities grew by 14.6 per cent.

The authors attributed this increase to differences in household endowments and, importantly, differences in returns to these endowments. In essence, the article argues that ethnic minorities in Vietnam have not benefited from the Doi Moi economic reform as greatly as the Kinh-Hoa majority, and that these reforms failed to address this growing inequality.

\subsection{Citizenship and ethnicity}

Three main articles constitute IDS' contributions regarding ethnicity and citizenship. These include an article on the meanings of citizenship in Latin America by Evelina Dagnino (2005), and two articles regarding citizenship in Nigeria by Oga Steve Abah and Jenks Zakari Okwori (2002, 2005). 
Dagnino (2005) presents a sweeping analysis that tackles the emergence of citizenship across Latin America. In doing so, she discusses how citizenship has been heavily influenced by identity politics. Black and indigenous movements linked their own identities with the redefinition of citizenship. Dagnino explains that this contributed to the recognition of collective rights relevant to Latin American indigenous groups. The debate this triggered not only affected a redefinition of citizenship but also stimulated important legal changes. The constitutions of Ecuador and Colombia, for example, now recognise their multi-ethnic nature. Likewise, in Brazil constitutional provisions include recognition of indigenous rights.

Abah and Okwori (2002, 2005), on the other hand, analyse the incompatibility between citizenship and ethnic identity in Nigeria. They explain how the notion of citizenship, constitutionally defined by ancestry and place of birth, is often rejected on the grounds that ancestry is traditionally the sole determinant of entitlement. In both articles the authors argue that the legacy of colonialism in Nigeria created a nation with an inherent power imbalance between its Northern and Southern states. They contend that access to resources continues to be based upon ethnic allegiance. As such, ethnic identities tend to be exclusionary and competing, which only further promotes incongruence between citizenship and ethnic identity.

The research of Dagnino (2005) and Abah and Okwori (2002, 2005) talk to the instrumentalist and constructionist nature of ethnicity. They build upon the work of Glazer and Moynihan (1975) and others to highlight the relationship between not only ethnicity and the state, but also citizenship.

\subsection{Ethnicity and violence}

The range of research produced by IDS on ethnic violence varies widely in its focus. The first piece, from Jean-Pierre Tranchant (2010), uses econometrics to investigate the relationship between fiscal decentralisation, institutions and ethnic violence. Assessing the association between institutions and ethnic conflict, he finds that poor bureaucratic competence directly contributes to ethnic violence. Yet, he also suggests that high bureaucratic competence correlates with ethnic mobilisation.

Arguing, therefore, that steps must be taken to protect ethnic minorities Tranchant then examines the impact of fiscal decentralisation - as such a step - on levels of violence. He finds that fiscal decentralisation is associated with less ethnic violence and reduces ethnic mobilisation among groups that are highly distinct from the majority or economically disadvantaged. While these results would suggest that fiscal decentralisation helps to reduce ethnic violence, the author calls for caution. Decentralisation has varying impacts on majority and minority groups. Tranchant's work speaks to the literature on ethnicity and the state. He not only advances debate on a niche topic, but also furthers understandings of the differential role of the state upon ethnic groups. 
A second contribution is that of Lind, Mutahi and Oosterom (2015) in their analysis of $\mathrm{Al}-\mathrm{Shabaab}^{4}$ and political volatility in Kenya. The authors investigate 'external' and 'internal' stresses contributing to violence; the former driven by Somalia's state collapse and conflict spillovers and the latter related to regional and ethnic divisions and heavy-handed security responses targeting Somalis and Muslims. Finding it is, in fact, the interaction of these stresses that is driving violence, Lind et al. demonstrate how the authorities have misidentified Kenya's security threat. They explain that while Al-Shabaab does indeed pose a continuing physical threat, they have more importantly exploited regional and ethnic tensions. The continuing externalisation of the threat by the Kenyan security forces has further politicised and deepened these ethnic and regional divisions, which in turn is feeding further violence.

Another critical contribution is provided by Jaideep Gupte (2012), who investigates 'ethnic riots' in India. He argues that studying such riots through an 'intercommunity' or 'interethnic' framing is inadequate, as the analysis does not fully capture the dynamics or impacts of such violence. He identifies five areas in which analysis adopting 'communal' or 'ethnic' frames is lacking and instead posits that analysis of riots should recognise the agency of individuals. This, he contends, would provide a more meaningful frame for the analysis of so-called 'communal' violence in India. Gupte's article is noteworthy for contributing to critiques regarding the over-ethnicised interpretation of social reality.

Lyndsay McLean Hilker's essay (Bagayoko and McLean Hilker 2009) addresses the importance and implications of identity politics with regard to security. She contends that viewing identity politics through either a primordialist or instrumentalist lens fails to capture the complexity of identity-based violence. Both approaches, she argues, negate the value of studying identity politics. Primordialist approaches view ethnic conflict as unavoidable, thereby shifting emphasis toward conflict mitigation. Instrumentalist approaches view ethnic violence as being about competition over resources or power, leading to the assumption that tackling grievances and mediating competing interests is the best course of action. However, McLean Hilker believes that identity politics matter for three main reasons. First, identity provides a powerful vehicle for collective mobilisation (positive or negative). Second, perceptions of inequality influence action. Third, the content of ethnic narratives and symbols are important to understand.

\subsection{Health and sexuality issues of indigenous and minority groups}

Three main contributions define IDS' research pertaining to health and sexuality issues of indigenous and minority groups. The first is that of Linda Waldman (2005), in which she analyses citizen mobilisation in relation to asbestos disease and litigation. Waldman explores the divergent interpretations surrounding a litigation case. The resolution of the case against Cape plc, a company mining asbestos in South Africa, was commonly seen as a success. The ruling was made in favour of the claimants. However, the claimants from Griquatown did not consider the outcome as positive. 
Waldman argues that this difference in perspective cannot be captured by theories of social mobilisation or millenarian movements alone. Instead, a linkage between these theories based on an interpretation of ethnic identity is required. In this regard, Waldman explains that the Griqua identity - with its ambiguous nature and its emphasis on religious retribution and restrictive notions of private property ultimately shaped the negative interpretation of the case.

The second set of contributions includes two special issue journals edited by Pauline Oosterhoff and colleagues (Oosterhoff et al. 2011, 2013). Oosterhoff et al. (2011) draw together a selection of articles investigating sexual and reproductive norms and behaviours in minority ethnic groups in Southeast Asia and Bhutan. Two main findings are drawn from the collected articles. The first relates to the side effects of modernisation policies in the region. The editors find that following the implementation of family planning, health and education programmes, large health inequalities between majority and minority ethnic groups have emerged. Moreover, in a number of countries these modernisation programmes promote the spread of dominant cultural practices among minority ethnic groups. Minority cultures are often misunderstood and viewed - drawing on colonial and contemporary stereotypes - as 'backward' and 'uncivilised'.

The second key finding includes the impacts of migration on expanding sexual networks. The editors explain that, in countries such as Vietnam and Indonesia, governments supported the resettlement of minority ethnic groups to remote areas. This resulted in the expansion of sexual networks, resulting in changing patterns of sexual behaviour and increasing vulnerability to HIV and other diseases for minority ethnic groups.

The second special issue journal by Oosterhoff et al. (2013), focuses on sexual and reproductive health challenges among indigenous and minority peoples in Asia, Africa and Latin America. The editors, again, note two main themes emerging from the collected articles. First, is the need to transform monocultural health systems. Such systems typically exacerbate misunderstandings and hostility with indigenous and minority groups and are often unable to address cultural sensitivities regarding sexuality. Second, is the impact of normative nationalist policies upon ethnic minority groups. New public health programmes promote gender norms held by the dominant ethnic majority. These programmes have unintended impacts upon ethnic minority groups that do not share such norms. Examples include the internalisation of new patriarchal attitudes and the reinforcing of gender inequalities.

While the contributions of Oosterhoff et al. $(2011,2013)$ contribute to debates on the varying impacts of the state upon ethnicity, they also highlight the intersection between gender and ethnic identity.

The final IDS contribution, by Alex Shankland (2010), discusses the representation of indigenous groups in deliberative spaces within the Brazilian health sector. His research makes the case for understanding 
three dimensions of representation: representation of issues for debate, representation of social groups to the state, and representation of the democratic process. With regard to the second of these dimensions representing social groups - Shankland discusses the manner in which the authenticity of representation is bound up with the performance of indigenous identity. This is manifest in the use of language and visual imagery, including dress, adornment and posture. He also highlights the tensions between the ethnic and racial identities relating to 'indigenousness', and the manner in which they are deployed to confirm and contest the legitimacy of representatives. Shankland's work highlights the intersection of ethnic and racial identities.

\subsection{Ethnicity and volunteering}

Alexandrea Picken and Simon Lewis (2015) make a distinctive contribution to the literature in their article on the impact of ethnicity on volunteering. Conducting research in both Mozambique and Kenya, the authors note that ethnic divisions are mirrored in the volunteer landscape, thereby reducing the effectiveness of volunteering. Yet, the authors also note that international volunteers and neutral national volunteers have a role to play in establishing trust between groups and in negotiating more representative relationships and structures. Concluding their article, Picken and Lewis suggest that volunteer organisations should think more strategically about how they can best utilise the 'neutral outsider' role of volunteers to reduce entrenched ethnic biases.

\subsection{Ethnicity, development and interethnic relations}

The final IDS contribution to ethnicity theory is the research of Naysan Adlparvar (2015). He examines the differential impacts of post-2001 political reconstruction and socioeconomic development upon ethnicity in Afghanistan's Bamyan Valley. Adlparvar argues that the acquisition of productive resources by Hazarahs and their increasing status is linked to growing tensions with Tajiks and Saadat, respectively. With regard to the former, the increasing salience of sectarian identity has contributed to growing tensions between Hazarahs and Tajiks. With regard to the latter, ethnicity has been used to legitimise, contest and violently enforce unequal marriage arrangements between Saadat and Hazarahs.

Finally, through his analysis, Adlparvar contends that ethnic identity in Afghanistan should be viewed in an intersectional manner - alongside racial, sectarian and gendered identities. He goes on to argue that the interrelationship between these forms of identity is constantly in flux. They assume greater or lesser salience, relevant to one another, depending upon time and context.

\section{New frontiers of research: intersectionality, geopolitics and development}

Three new frontiers of research are identified based on the previous discussion. These include the integration of intersectionality into ethnicity theory, the importance of expanding research linking ethnicity and development, and investigation of new framings of identity and social organisation driven by changing global geopolitics. 
The overview of ethnicity theory, presented earlier in this article, highlighted the insights emerging from postmodern critiques in the ethnicity literature. Chief among these is the growing importance of integrating intersectionality into thinking regarding ethnicity. Such integration could have a number of implications.

First, a widening of the scope of analysis would be required when examining intergroup dynamics. This might be achieved by investigating not only the manner in which different axes of identity intersect with one another, but also the different ways individuals are positioned in relation to existing power hierarchies. Second, intersectionality could broaden inquiry of group-based inequalities. For example, Kabeer (2010) identifies four types of inequalities - cultural, spatial, economic and political that are mutual and intersecting, and which reinforce patterns of social exclusion. Third, is the potential for intersectionality to challenge the reification of forms of identity, otherwise viewed as static and unchanging.

There is also, however, a potential risk that research on intersectionality becomes appropriated in such a manner so as to perpetuate reified identities such as the 'Asian lesbian feminist' leading, in turn, to assumptions that individuals will necessarily always act according to those identifiers. Another potential concern is that it may be assumed that all forms of identity can be examined in the same manner. Or assumptions are made about how these identities work together, which unintentionally 'freezes' them in time. This may result in a failure to capture the manner in which the relationship between intersecting identities constantly changes.

Finally, while intersectionality offers new insights into understanding identity, it bears limited explanatory power in clarifying why particular aspects of identity assume more weight than others in influencing individual and collective behaviour. There is still much research needed on what intersectionality means for agency, mobilisation and social change.

The review of IDS' contributions to the literature on ethnicity indicates a second potential area of future research. Although not a new area of inquiry per se, there is still a need to expand research investigating the link between ethnicity and development. Further research of the impact of development policy and programming upon ethnicity - such as the work of Baulch et al. (2012), Tranchant (2010) or Oosterhoff et al. (2011, 2013) - would do much to inform understandings of inequality, violence, and sociocultural change. On the other hand, continued investigation of the role ethnicity plays in shaping developmental processes - similar to research by Dagnino (2005), Waldman (2005) or Picken and Lewis (2015) - could contribute to thinking on social mobilisation, conflict sensitivity or the formulation of improved development policy.

The topics of inquiry indicated above are not the only new frontiers of research on ethnicity. As mentioned in the opening paragraphs of this article, it is not just within academia that ethnicity remains salient. It continues to be relevant in the social and political life of people across 
the globe. The changing geopolitical landscape witnessed largely since the events of 9/11 has stimulated major shifts in popular conceptions of ethnicity (and other forms of identity) and in associated patterns of social and political organisation. In addition to new areas of research generated from debates in the academic literature, the nature of identities emerging from these new geopolitical arrangements also requires investigation.

The events of 9/11 have placed Islam at the centre of global politics. They resulted in the invasions of Afghanistan and Iraq. Both of which, plus the unfolding crisis in Syria, have resulted in the manipulation and growing polarisation of ethnic and sectarian identities. Questions remain as to how these framings of identity intersect and how they further violence? The collapse of boundaries in two Middle Eastern countries (Syria and Iraq) also challenges notions of the 'nation state' and national identity. The corresponding rise of the so-called Islamic State - and their common identity used to recruit from across the globe - questions the relationship between identity, geography and 'groups' in fundamental ways. The resulting spread of refugees across West Asia, the Middle East and into Europe is likely to have a major impact on intergroup relations, potentially altering conceptions of the 'we' and undermining the idea of the ethnic 'other' residing in the global South. The resurgence of right-wing political parties and their mobilisation around ethnicised forms of identification, against perceived enemies but also in celebration of imagined histories, has been witnessed worldwide - not only in the global South but also in countries like France, Germany and the United States. How does this inform understandings of the way culture is deployed for political gain?

Future research will also likely have to uncover the appropriation of ethnicity within the literature itself. With the sense of pending threat posed by the so-called Islamic State and other Islamist groups to the West, a 'securitisation' of research on ethnicity may emerge. Studies in counter-terrorism may influence research on ethnicity and culture, possibly infusing it with conceptions of which cultures represent 'threats', and how certain cultural forms allow for the development of social networks and mobilisation for violence.

Unpacking the politics surrounding the usage of ethnicity in academia, policy and everyday life is as important today as it was half a century ago, when it emerged as a scholarly field. This is particularly timely given the new appropriations and framings of ethnicity - and indeed other forms of identity - that new global geopolitics have shaped. Undertaking such inquiry requires expanded analytical frameworks, which both question the positionality of those who research ethnicity and accommodate the intersectional nature of identity.

These are new frontiers that IDS is well positioned to contribute to. This is not only because of the Institute's historic engagement with research on ethnicity and development, but also because the study of ethnicity is synonymous with the study of power, inequality and social change. 


\section{Notes}

1 For a well-informed overview of the ethnicity literature see Banks (1996) and Kaufmann (2005). See also Wan and Vanderwerf (2009).

2 This tri-partite division is borrowed from Fearon and Laitin (2000).

3 A number of other contributions by IDS scholars refer to ethnic or indigenous groups, but do so largely in an incidental manner and, therefore, have not been included in this article. Examples include Devereux and Sabates-Wheeler (2004) and Lister (2004).

4 Al-Shabaab is a Somalia-based jihadi organisation.

\section{References}

Abah, O.S. and Okwori, J.Z. (2005) 'A Nation in Search of Citizens: Problems of Citizenship in the Nigerian Context', in N. Kabeer (ed.), Inclusive Citizenship: Meanings and Expressions, London: Zed Books

Abah, O.S. and Okwori, J.Z. (2002) 'Agendas in Encountering Citizens in the Nigerian Context', IDS Bulletin 33.2: 1-8, http://bulletin.ids.ac.uk/ idsbo/article/view/1213 (accessed 23 March 2016)

Adlparvar, N. (2015) "When Glass Breaks, It Becomes Sharper": De-Constructing Ethnicity in the Bamyan Valley, Afghanistan', $\mathrm{PhD}$ thesis, Brighton: IDS

Bagayoko, N. and McLean Hilker, L. (2009) Essays on Transforming Security and Development in an Unequal World, IDS Working Paper 322, Brighton: IDS

Banks, M. (1996) Ethnicity: Anthropological Constructions, London: Routledge Barth, F. (1998 [1969]) Ethnic Groups and Boundaries: The Social Organisation of Cultural Difference, 2nd ed., Long Grove IL: Waveland Press

Baulch, B.; Pham, H.T. and Reilly, B. (2012) 'Decomposing the Ethnic Gap in Vietnam, 1993-2004', Oxford Development Studies 40.1: 87-117

Carter, B. and Fenton, S. (2009) 'Not Thinking Ethnicity: A Critique of the Ethnicity Paradigm in an Over Ethnicised Sociology', fournal for the Theory of Social Behaviour 40.1: 1-18

Cohen, A. (1969) Custom and Politics in Urban Africa: A Study of Hausa Migrants in Yoruba Towns, London: Routledge

Collins, P. and Chepp, V. (2013) 'Intersectionality', in K. Celis, J. Kantola, G. Waylen and L. Weldon, The Oxford Handbook of Gender and Politics, Oxford: Oxford University Press

Comaroff, J. and Comaroff, J. (1992) Ethnography and Historical Imagination, Boulder CO: Westview

Combahee River Collective (1977) Combahee River Collective Statement, http://circuitous.org/scraps/combahee.html (accessed 23 December 2012)

Crenshaw, K. (1989) 'Demarginalizing the Intersection of Race and Sex: A Black Feminist Critique of Antidiscrimination Doctrine, Feminist Theory and Antiracist Politics', University of Chicago Legal Forum 1989.1: 139-67

Dagnino, E. (2005) Meanings of Citizenship in Latin America, IDS Working Paper 258, Brighton: IDS

Davies, C.A. (2008) Reflexive Ethnography: A Guide to Researching Selves and Others, 2nd ed., London: Routledge 
Devereux, S. and Sabates-Wheeler, R. (2004) Transformative Social Protection, IDS Working Paper 232, Brighton: IDS

Eriksen, T.H. (2002) Ethnicity and Nationalism: Anthropological Perspectives, Culture, Anthropology and Society Series, 2nd ed., London: Pluto Press

Fearon, D.J. and Laitin, D.D. (2000) 'Violence and the Social Construction of Identity', International Organization 54.4: 845-77

Glazer, N. and Moynihan, P.D. (1975) Ethnicity: Theory and Experience, Cambridge MA: Harvard University Press

Gupte, J. (2012) What's Civil About Intergroup Violence? Five Inadequacies of Communal and Ethnic Constructs of Urban Riots, MICROCON Research Working Paper 62, Brighton: IDS

Hechter, M. (1978) 'Group Formation and the Cultural Division of Labour', American Fournal of Sociology 84.2: 293-318

Jenkins, R. (2008) Rethinking Ethnicity: Arguments and Explorations, 2nd ed., London: Sage Publications

Kabeer, N. (2010) Can the MDGs Provide a Pathway to Social Fustice? The Challenge of Intersecting Inequalities, MDG Achievement Fund, Brighton: IDS

Kaufmann, C. (2005) 'Rational Choice and Progress in the Study of Ethnic Conflict: A Review Essay', Security Studies 14.1: 178-207

Lind, J.; Mutahi, P. and Oosterom, M. (2015) Tangled Ties: Al-Shabaab and Political Volatility in Kenya, IDS Evidence Report 130, Brighton: IDS

Lister, S. (2004) The Process and Dynamics of Pastoralist Dynamics in Ethiopia, IDS Working Paper 220, Brighton: IDS

Oosterhoff, P.; White, J. and Aggleton, P. (2011) 'Editorial Introduction', Culture, Health and Sexuality 13.2: 181-4

Oosterhoff, P.; Lyttleton, C.; van der Kwaak, A. and Aggleton, P. (2013) 'Editorial Introduction', Culture, Health and Sexuality 15.3: 335-7

Picken, A. and Lewis, S. (2015) 'The Impacts of Politics and Ethnicity on Volunteering', IDS Bulletin 46.5: 54-68, http://bulletin.ids.ac.uk/ idsbo/article/view/65 (accessed 23 March 2016)

Shankland, A.J.L. (2010) 'Speaking for the People: Representation and Health Policy in the Brazilian Amazon', PhD thesis, Brighton: IDS

Tranchant, J.P. (2010) 'Essays on Fiscal Decentralisation, Institutions and Ethnic Conflict', PhD thesis, Clermont-Ferrand: University of Auvergne

Waldman, L. (2005) When Social Movements Bypass the Poor: Asbestos Pollution, International Litigation and Griqua Cultural Identity, IDS Working Paper 246, Brighton: IDS

Wan, E. and Vanderwerf, M. (2009) A Review of the Literature on Ethnicity, National Identity, and Related Missiological Studies, www.globalmissiology.org (accessed 2 June 2013)

Wetherell, M. (2010) 'The Field of Identity Studies', in M. Wetherell, and C.T. Mohanty (eds), The Sage Handbook of Identities, London: Sage Publications 


\title{
Is Openness Enough?
}

\author{
Hani Morsi and Alison Norwood
}

\begin{abstract}
Openness, applied in scholarly and research practices, has garnered increasing interest in recent years. With the broadening reach of Open Access as an alternative scholarly publishing model, there is anticipation that open scholarship practices will produce desirable outcomes for research and access to knowledge. The purpose of this article is twofold: firstly to highlight that Open Access is more than just the removal of paywalls, and that it is part of a wider set of open practices that can potentially yield a more collaborative and equitable global landscape of knowledge production. Secondly, to present the IDS Bulletin as a case study for an Open Access publication that has evolved to adapt to a changing scholarly publishing landscape. By critiquing prevalent discourse on openness alongside this case study, we hope that this article contributes to conversations on issues at the intersection of open scholarship, collaborative research and equitable access to knowledge.
\end{abstract}

\section{What do we mean when we talk about openness?}

Openness, as in 'open research', or 'Open Access', covers a range of diverse scholarly, educational and knowledge communication practices that have garnered wide attention in recent years (Wiley 2006; Wiley and Hilton 2009). Practices associated with openness are often synonymous with activities taking place in electronic environments, access to which is proliferating globally at an incredibly rapid pace. Research on the role of openness generally anticipates that broadening access to knowledge will contribute significantly to promoting more equitable and effective reach and impact of research and scholarship, yet as a phenomenon associated with Internet-based technologies, open approaches to providing unrestricted access to peer-reviewed research remains a topic mired in debate. This debate raises questions about how research outputs should be disseminated and communicated more openly, and ways to fund this process. It also asks whether or not open approaches to research dissemination have universally valuable impact. Wiley and Green note that 'only time will tell' as to whether open practices will be truly transformative or whether it 'will go down in the history books as just another fad that couldn't live up to its press' (2012: 88). 
Still, openness, in the more fundamental meaning of the term as it relates to knowledge, isn't new. The wide spectrum of opportunities and technological novelty afforded by the Internet often leads to the erroneous assumption that the value of collaborative knowledge production, and the open exchange and sharing of ideas is a new feature of our modern times. Thus, perhaps a useful point of departure within the discourse on Open Access and - more broadly - open research is the fundamental distinction between provision of unrestricted access to research outputs, which is often what is meant when the term 'Open Access' is discussed, and adopting open approaches along the whole research process, which are the intended primary objectives of many advocates of expanding scholarly openness. All too often, contemporary debates on openness are reduced to issues of merely improving access (see Balon 2014; Liesegang 2013; Salem and Boumil 2013; Apuzzo 2103; Wolpert 2013; and Haug 2013), which is important in its own right, but opening up access to research outputs, in and of itself, is not enough for realising the oft-heralded transformative potential of modern information and communications technologies (ICTs) for knowledge production and dissemination.

\subsection{Openness and the academic journal: change and continuity}

Following the aforementioned distinction between making the final research accessible and opening up the various stages of the research process, it should be noted that collaborative knowledge production, as the broader objective of open research (as opposed to Open Access, which could be thought of as a subset of open research), isn't exclusive to our present time. Long before the advent of modern ICTs, scholars created networks of knowledge that traversed national borders. These networks came to be known as republica literaria, or Republic of Letters (Casanova 2004). The Republic of Letters was a vibrant network of Enlightenment intellectuals who created the earliest exemplification of the core ethos of openness as we understand and discuss it in the present day. Correspondence by letter was the precursor to the modern academic journal system. The academic journal, in its present day form, and as the main contemporary system of distribution of expert-vetted knowledge, is a legacy of a system that was created three and a half centuries ago. The striking irony is that the modern academic publishing system, with all the ease of copying and distribution that the Internet now provides, impedes a valuable element that simple letter correspondence offered: an unrestricted two-way interaction that created a lively, open discourse that cultivated a rich dialectic on the intellectual issues of the time.

Without a doubt, the intellectual landscape of the Age of Enlightenment was rather different from that of the Age of the Internet (as are the economic and political landscapes). Gone is the era of polymaths and the fluid boundaries between disciplines, and the increasing disciplinary specialisation of contemporary research means that a knowledge sharing and distribution system that prioritises expert academic vetting and review will simply mirror the increasing complexity of today's knowledge terrain, regardless of the degree of unrestricted access. Things have 
changed significantly since the establishment of the first academic journal in the 1660s by Henry Oldenberg (Kronick 1990). With the Internet being a far superior medium for knowledge distribution than print copies, it becomes evident that the modern commercialisation of the journal system has introduced disincentives to capitalising on the immense potential afforded by Internet-based technologies, for revolutionising research collaboration and knowledge co-production in unprecedented ways. The dominant format of academic publishing is an arduously long and incredibly inefficient workflow, the output of which is often knowledge that then gets locked behind a paywall. Additionally, and aside from restricted or exorbitantly expensive access, the highly competitive nature of publishing in academic journals discourages scholars from sharing research before it achieves a final 'publishable' form, and thus the primary characteristic of the global ecosystem of scholarly production becomes competition, not collaboration.

\subsection{Beyond the academic journal}

Without a doubt, there are other factors, aside from the journal system, that also hinder the collaborative potential of research in various disciplines, including (and most notably) systemic institutional mechanisms in professional academia (Benner and Sandström 2000). Therefore, when we talk about openness, we should not limit the conversation to access, but also consider the ways by which knowledge that becomes open could be used in ways that capitalise on the technological possibilities of our time, as well as how the prevailing institutional mechanisms that regulate academic research enable or hinder collaboration. Research is fundamentally about discourse, but it has been malformed, primarily by the hegemony of the journal system (and by consequence of the other aforementioned factors), into a taxing process of dissertation and vetting. The contemporary academic publishing landscape creates a false logic of scarcity of ideas, which has negative implications for how new knowledge is created. Perhaps this rising awareness is what inspired the theme of the 2015 International Open Access Week, 'Open for Collaboration'. ${ }^{1}$

There is a palpable awareness in contemporary academia, and arguably especially in international development research, about how the ever-increasing complexity of our world requires new, or at least unconventional, approaches to creating new knowledge. There is also no shortage of innovative thinking. The problem is often that much of this thinking, and the high quality research that is often the result of it, happens in disciplinary silos. While not solely a problem of access, paywalled research and the current academic publishing system certainly exacerbates this isolation. The lack of adequate collaborative knowledge production on complex issues is largely a product of a research publishing process that discourages openness and collaboration (Nosek et al. 2015; Markram and Markram 2011). Alternatives to the academic journal format are emerging, and many incipient options are not just in response to the 'oligopoly of academic publishing' (Larivière, Haustein and Mongeon 2015) in terms of addressing the problem of 
access, but also specifically recognising that the research process is about a lot more than provision of access. For example, the new Open Access journal RIO (Research Ideas and Outcomes) 'aims to catalyse change in research communication by publishing ideas, proposals and outcomes in a comprehensive way'. ${ }^{2}$ Another Open Access journal, The Winnower, ${ }^{3}$ focuses on the whole review and publishing process, from start to finish. Moreover, institutional repositories (IRs) are becoming more pervasive, with benefits that include maximising research impact, especially in terms of the research output on the institutional level, and giving scholars more control over the process of research communication, which the conventional model of commercial publishing restricts (Chan 2004).

\section{Open Access publishing}

While initiatives around collaborative teaching and learning began with the introduction of the World Wide Web in the early 1990s, with early Internet systems allowing comparatively open softwaresharing in universities, and Massive Open Online Courses (MOOCs) from 2008 supplying both training course materials and community forums with discussion spaces for students and professors, it was only once researchers made a collective move that the concept of Open Access regarding publishing took off. It was after 2002 and the pivotal Budapest Open Access Initiative ${ }^{4}$ that commercial academic publishers such as Wiley, Taylor \& Francis, and Elsevier, began to recognise the demand for a fundamental shift towards a more 'open' publishing model and adapted to this by bringing in Article Processing Charges (APCs). For an often not-insignificant fee (which could be as high as US\$3,000) articles would be made 'free at the point of access' and authors could offer licensing of their material to the reader with some degree of reuse of that material - with the APCs serving as compensation for the publishers for lack of revenue from subscriptions, which would, it was assumed, decline if articles were free to view online. This form of Open Access become known as the 'gold' route. However, such substantial charges led to intense debates such as those led by the UK newspaper, The Guardian, ${ }^{5}$ which recognised both opportunities and challenges offered by Open Access in its various forms, including those within the academic community - a community with obligations to publish in high-profile journals. Would this fee-paying option inevitably lead to only those authors with institutional or research programme backing being able to afford to publish? Would peer review decline if payment was perceived as the only qualification for publication? Would the whole 'author-pays' concept wind up at the dreaded end point of the previously much-vilified model of vanity publishing, ${ }^{6}$ unauthenticated by rigorous academic editorial processes?

Staunch Open Access advocates, such as Peter Suber (whose overview of Open Access definitions first published in 2004 still remains relevant) ${ }^{7}$ and Alma Swan (whose guidelines on Open Access policy partly informed the Institute of Development Studies' (IDS) own policies (Swan 2012)), were also unsatisfied with the APG model. All the time that commercial publishers applied charges for 'immediate access/gold' publication - or 
their alternative option of allowing only pre-peer-reviewed article versions into IRs (known as the 'green' model) while imposing an embargo on full access publication on their websites for up to two years (while still ensuring income from subscribers during this embargo period) - a mixed economy operated, with continuing barriers to the reader, thereby obviating true 'openness'. At this stage, mega-journals such as PLOS ONE ${ }^{8}$ and BioMed Central ${ }^{9}$ were created, with innovative high article volume business models resulting in comparatively lower APGs and quicker-thantraditional overall publication production times.

As Alison Jones puts it, in the Book Machine blog,

Scholarly publishing $[\ldots]$ has been in a state of disruption for decades now. The classic outputs, little changed for centuries, have been the journal articles and the monograph, and the traditional customer and curator of the content remains the university library, but the World Wide Web - originally designed for the communication of scholarly material, of course - disrupted the established print models, and publishers and academics alike have been exploring, exploiting and expanding the possibilities ever since (Jones 2015).

As educational institutions and learned societies alike began experimenting with their own new publishing business models to accommodate the complete shift required by Open Access - that the author rather than the reader pay for publication - new variants of publishing models came into play. The Outsell report on Market Size, Share, Forecast, and Trends (Outsell 2015) found at least 11 different models in operation, ranging from straightforward APCs, to institutional funding, to partnerships with similar organisations, to sponsorship and in some cases - entirely voluntary staff, both contributors and editorial.

\subsection{Open Access and IDS}

The IDS Bulletin is the Institute of Development Studies' flagship publication. Starting just two years after the Institute was founded, in 1968, the IDS Bulletin has been in continuous publication ever since, initially published in-house under a subscription business model, then from 2009 to 2015 co-publishing with Wiley and continuing under a subscription model, and from January 2016 as an in-house publication again, only this time under an Open Access model with articles available to freely download and re-use. These evolutions reflect the Institute's recognition of the necessity of changing with the publishing landscape, of aiming for wider reach and impact when signing with Wiley, and then with further ambitions to continue this reach while still fulfilling emerging funder and reader demands as an Open Access journal today. The co-author, Alison Norwood, has worked in the IDS Communications Unit since 2000 and has been directly involved in both the move to and away from commercial publishing in the intervening 15 years.

The IDS Bulletin's purpose has always been to reflect IDS' and its partner organisations' cutting edge research within development, 
focusing on both academic and policy-oriented pieces, many of which are co-written by Southern partners, benefiting from their lived experiences and knowledge sharing. Since 2010, 46 per cent of IDS Bulletin articles have been written by Southern contributors, and the ongoing aim is to increase this percentage still further in the future.

When considering the next steps for the IDS Bulletin once reaching the end of the Wiley contract in late 2015, it could not be assumed that contributors - wherever in the world they were based - could afford substantial APCs. During the last two years of the Wiley contract, the opposing mandates from IDS' funders to produce gold Open Access material diametrically conflicted with the authors' ability to pay the APGs which Wiley would have required to achieve this access. Add to this the royalties received by IDS from Wiley's subscription model (which covered editorial staffing and production costs of the IDS Bulletin and that of some other Institutional series publications), and the potential financial hole that would result if the Institute withdrew from this commercial model, and it was clear that IDS had to reflect seriously on how to keep all the stakeholders happy while still meeting the growing imperatives of Open Access publishing principles. That is, producing articles free at the point of publication for both downloading and re-using through the various Creative Commons licensing options which by this point had become the chief form of open licensing. ${ }^{10}$

How IDS communicates its research findings and their resulting impact has long been a core element of IDS' strategic plan, and as early as 2010 IDS had launched its own green Open Access route through the creation of OpenDocs, ${ }^{11}$ the official institutional repository designed to hold versions of IDS authors' and partner research centres' and consortia's literature works. Working closely with Southern partners, just two years later the BLDS Digital Library ${ }^{12}$ was also launched, containing digitised library holdings available under a Creative Commons licence, on behalf of research organisations in Africa and Asia. However, even this strong Open Access base could not encompass the articles in the IDS Bulletin, which - while still under contract with Wiley - would remain behind a paywall and without licensing allowing any open re-use. Any pre-peer-reviewed articles downloaded into OpenDocs to meet green Open Access conditions were still considered insufficient by IDS' funders. It was apparent, therefore, that none of the existing fledgling experimental open journal models suited the IDS Bulletin.

In 2012 the Finch Report, on expanding access to published tax-payerfunded research findings, mandated gold Open Access in the UK and thus finally set in motion a sequence of discussion and decision-making across both the publishing and academic sectors (Finch Group 2012). The co-author attended a whole series of events around these Open Access debates, including 'Implementing Finch' in November 2012, 'Open Access, A Scientific Revolution for Southern Countries?' and 'The Future for Open Access and the Move Towards Open Data' in March 2015, and 'The Next Steps for Open Access in Higher Education' 
in January 2016. These events ranged initially from the purely theoretical prospect of increasing gold openness, towards the acknowledgement that openness was inevitable and not only for the final published literature results in journal article format, but also the underlying data behind the research results, and - as a new trend - academic monographs too. ${ }^{13}$

After three years of debate within IDS following on from the Finch Report, on the appropriateness of various Open Access business models, the only acceptable conclusion for the IDS Bulletin's continued success of its chosen special issue-themed concept was publishing as a gold Open Access journal in-house at the natural and amicable end of the Wiley contract arrangement.

These internal debates have been inclusive of many areas of existing expertise within the Institute - from the Communications Unit's perspective of years of combined publishing experience, to the library team's extensive knowledge of setting up the two IRs mentioned above, to the Research Fellows' experience from years of publishing through high prestige (albeit commercial) publishers. The following business models were considered: continued publication with Wiley on the existing arrangement of Open Access only possible through APCs; a hybrid model with Wiley, whereby some articles would be Open Access through payment but other articles would remain behind a paywall through the subscription model; options offered by other commercial publishers whose Open Access charges might be slightly less prohibitive; and the initially daunting prospect of publishing in-house again.

While IDS had published the IDS Bulletin in-house prior to the Wiley arrangement, the new publishing landscape was vastly different to those pre-commercial-contract years. In addition, the lack of royalties from any kind of subscription model could only result in an imbalance of the books regarding essential expenditure on the editorial processes required to produce each issue. This led to the early conclusion that sponsorship and/or advertising, combined with some Institutional or research project funding, would be the means to enable survival of the journal initially - with the forward-looking strategic plan to grow a new open online resource ${ }^{14}$ available to all, while retaining and increasing the necessarily strict peer review and editorial processes already firmly established.

Even once the decision had been made to produce the journal under sole IDS publication and offer articles as freely downloadable without embargo, the next set of decisions fell to choosing the most appropriate suite of Creative Commons (CG) licensing options to suit both IDS funder requirements and author preferences. After a year to make the initial business model decision, the specific licensing requirements for the relaunched online version of the journal then took another year to clarify. While Open Access advocates both institutionally and more widely would always claim that the most liberal CG BY licence is the only acceptable open route, others - whether academic or publishingfocused - have concerns about potential misuse of material offered by 
such a broad disclaimer. ${ }^{15}$ Some instances, if rare, of re-used material being taken out of the originally intended context and being politically misrepresented, or articles being repackaged into new compilations for large commercial sums (such as educational textbooks compiling open content and reselling for up to US\$100) meant that the Institute decided to recommend two non-commercial publication options as well - CG BY-NG, ${ }^{16}$ and the most prohibitive licence, CG BY-NG-ND. ${ }^{17}$

\subsection{Future aims of the new, open IDS Bulletin}

The demonstrable impact of IDS Bulletin articles is a key part of driving the journal forward, and increased availability through the gold Open Access model is an assumed advantage towards reaching both established and new audiences more quickly. The IDS Bulletin's usage (amount of article downloads) was already very healthy ${ }^{18}$ under Wiley's influence and will continue to grow under sole IDS publication through existing IDS networks and far-reaching social media connections. Fast turnaround issues with short lead-in times, such as that on the Arab Spring (Tadros 2011), ensure that IDS' research thinking is available for public viewing in months rather than years.

Collaboration with Southern partners also continues to be an important indicator, building on past successes of issues with significant media attention ${ }^{19}$ generated by the then-IDS director with co-editors from the Aga Khan University and the Collective for Social Science Research (both based in Karachi) on undernutrition in Pakistan (Haddad, Bhutta and Gazdar 2013) and with Oxfam on food justice in India (Haddad, Chandrasekhar and Swain 2012). The latter issue was specifically commissioned to coincide with, and influence, the National Food Security Bill which was working its way through the Indian parliament at the time.

The move towards a gold Open Access model funded in large part by sponsorship or fundraising is a comparatively bold one, reliant on meeting success criteria for both readers and research funders alike. It is hoped that by making articles available to both freely access and re-use, and by continued encouragement of contributions by Southern partners, the unique nature of the IDS Bulletin will continue in its special issue format for many years to come. The aim is for the journal to become known as an outlet for collaborative working between IDS and its partner organisations, encouraging debate between contributors in different countries and with potentially different viewpoints on any given theme. In addition, by building on 48 years of archive material, the new IDS Bulletin web resource platform will offer additional specialthemed issues combining the republishing of older but still significant articles with new commentaries on the current state of the debate to bring the evolution of ideas and discussion into fresh focus. As the in-house model develops its own monitoring and evaluation statistics and translates these into impact stories for both readers and authors, careful recording of any increases in download or citation figures will be undertaken, in order to build on successful articles and encourage further contributions for impactful and collaborative future issues. 


\section{Conclusion: charting the future of open and collaborative research}

If the success of the Open Access movement in the past several years is a sign of things to come, then it should be expected that there will be a rising tide of change in the global landscape of knowledge and scholarly communication. Despite the lack of strong correlation between a journal's Open Access status and its impact (Davis 2006; Davis and Fromerth 2007; Gargouri et al. 2010; Moed 2007), what is more evident is that 'wherever there are subscription-based constraints on accessibility, providing Open Access will increase the usage and citation of the more useable and citeable papers' (Gargouri et al. 2010: 18). As a result, some scholars expect that such Open Access-driven increase in usage may lead to research that is characterised by greater reach and impact on a global scale (Getz 2005: 19). Looking forward, the volume and quality of openly accessible content will be on the rise as research communities, institutions and various disciplines respond and contribute to the emerging landscape of Open Access research, but provision of unrestricted access is only the start of a true transformation in how knowledge is created, shared and communicated. The demand for more openness is indeed driven significantly by a growing realisation that truly collaborative modes of knowledge production must be created by opening up the various stages, tools and outputs of the research process, culminating in unrestricted access to and communication of research. As policy frameworks for openness emerge in response to this demand, openness will proliferate more widely (on the global and the disciplinary axes) as well as deeply (along the whole research process), but along with this proliferation comes new challenges. Disparate policy responses mean that the often varying Open Access institutional requirements can present new limits on the collaborative potential that would be facilitated by such increasing reach of Open Access research. Therefore, as highlighted in the case of the IDS Bulletin discussed in this article, formulating an institutional Open Access policy needs to account appropriately for responding to the changing scholarly publishing landscape, the demands of producing research that responds to critical issues in a timely manner, as well as ways to further enable and improve collaborative knowledge production with research partners.

With all the possibilities for radically transforming research collaboration and knowledge sharing that Internet-based technologies offer, limiting the discourse on openness to issues of access will restrict the horizon of these possibilities to provision of access, which is - essentially - a legacy of a publishing business model that created value and made sense in a world that predates the Internet. The Open Access movement is much wider than the removal of paywalls. The discourse on openness should include conversations on what openness means when it comes to collaboration on quality research that focuses on the world's most pressing issues, and the ways in which the current academic publishing format, as well as current institutional mechanisms of funding research, enable or hinder this potential.

A publication process that causes important research to get stuck in what is often a painfully long review process does not contribute to a 
vision of what open and collaborative research could look like. This is also true for a process that doesn't account for the fact that research in its formative stages can make equally important contributions, and that getting the final outputs in 'publishable' format should not always be the endgame of research communication. The conversation on access to research should also include other aspects of the political and moral economy of knowledge that characterise today's technology-driven world. In considering issues that go beyond opening up access to research outputs, we can advance the questions currently being raised about how research is created, published and shared to be more inclusive of a broader global knowledge agenda. Regarding the transition in academic publishing from print to digital and from restricted to open (in all its various flavours), the Open Access model is the first step towards truly transformative thinking in knowledge co-production and sharing, and is only the conversation starter on what the future of knowledge looks like in this increasingly complex and connected world.

\section{Notes}

1 Open Access Week is an annual global scholarly communication event focusing on open access and related topics. It takes place during the last week of October in a multitude of locations both on- and offline. The theme for Open Access Week 2015 was 'Open for Collaboration'.

2 http://riojournal.com/about.

3 https://thewinnower.com/about.

4 For original statement see www.budapestopenaccessinitiative.org/ read. Ten years on (in 2012) a coalition of scientists, foundations, libraries, universities and Open Access advocates updated new recommendations with the intended purpose of increasing openness of research in order to usher in huge advances in the sciences, medicine and health (see www.budapestopenaccessinitiative.org).

5 www.theguardian.com/higher-education-network/blog/2012/ aug/10/uk-open-access-research-debate-round-up.

6 A model whereby any author could publish without any quality criteria being applied.

7 http://legacy.earlham.edu/ peters/fos/overview.htm.

8 www.plosone.org.

9 www.biomedcentral.com.

10 https://creativecommons.org/licenses.

11 http://opendocs.ids.ac.uk/opendocs.

12 http://opendocs.ids.ac.uk/opendocs/handle/123456789/3.

13 Monographs are defined as detailed written studies of a single specialised subject or an aspect of that subject; and as such were initially considered too lengthy and resource-consuming to be produced with an author-pays model. However, at the time of writing momentum is currently building towards changing monograph business models too, with seminars such as 'Alternatives to the Monograph' being held at the University of Sussex, UK, in November 2015 during Academic Book Week, and attended by the co-author.

14 http://bulletin.ids.ac.uk/idsbo/index.

15 https://creativecommons.org/licenses/by/4.0. 
16 https://creativecommons.org/licenses/by-nc/4.0.

17 https://creativecommons.org/licenses/by-nc-nd/4.0.

18 According to Wiley Publisher Reports, against similar journals within the development genre.

19 www.dawn.com/news/1049431/investing-in-nutrition.

\section{References}

(All urls accessed 1 March 2016, unless otherwise stated.)

Apuzzo, M.L.J. (2013) 'Acquiring Wisdom in the Information Age', World Neurosurgery 79.5-6: 595-6, www.sciencedirect.com/science/ article/pii/S1878875013004968

Balon, R. (2014) 'Perilous Terra Incognita - Open-Access Journals', Academic Psychiatry 38.2: 221-3, http://dx.doi.org/10.1007/s40596014-0059-1

Benner, M. and Sandström, U. (2000) 'Institutionalizing the Triple Helix: Research Funding and Norms in the Academic System', Research Policy 29.2: 291-301, www.sciencedirect.com/science/ article/pii/S0048733399000670

Casanova, P. (2004) The World Republic of Letters, Cambridge MA: Harvard University Press, https://books.google.co.uk/books?id=_1AoeXbMSZMC

Chan, L. (2004) 'Supporting and Enhancing Scholarship in the Digital Age: The Role of Open-Access Institutional Repositories', Canadian Journal of Communication 29: 277-300, http://eprints.rclis.org/5648/1/ Chan_CJC_IR.pdf

Davis, P.M. (2006) 'Do Open-Access Articles Really have a Greater Research Impact?', College and Research Libraries 67.2: 103-4, http:/ / ecommons.library.cornell.edu/handle/1813/2881

Davis, P.M. and Fromerth, M.J. (2007) 'Does the ArXiv Lead to Higher Citations and Reduced Publisher Downloads for Mathematics Articles?', Scientometrics 71.2: 203-15

Finch Group (2012) Accessibility, Sustainability, Excellence: How to Expand Access to Research Publications: Report of the Working Group on Expanding Access to Published Research Findings, www.researchinfonet.org/publish/ finch/ (accessed 26 August 2015)

Gargouri, Y.; Hajjem, C.; Larivière, V.; Gingras, Y.; Carr, L.; Brody, T. and Harnad, S. (2010) 'Self-Selected or Mandated, Open Access Increases Impact for Higher Quality Research', PLOS ONE 5.10, p.e13636, www.pubmedcentral.nih.gov/articlerender. fcgi? artid $=2956678 \&$ tool $=$ pmcentrez\&rendertype $=$ abstract

Getz, M. (2005) 'Open Scholarship and Research Universities', paper presented at Middlebury College Conference, Vermont, 30 April 2005, https://ecommons.cornell.edu/bitstream/handle/1813/1344/ GetzOpenScholarship18May05.pdf? sequence = 1\&isAllowed=y

Haddad, L.; Bhutta, Z.A. and Gazdar, H. (2013) 'Seeing the Unseen: Breaking the Logjam of Undernutrition in Pakistan', IDS Bulletin 44.3, http://bulletin.ids.ac.uk/idsbo/issue/view/25

Haddad, L.; Chandrasekhar, C. and Swain, B. (2012) 'Standing on the Threshold: Food Justice in India', IDS Bulletin 43.S1 
Haug, C. (2013) 'The Downside of Open-Access Publishing', New England Fournal of Medicine 368.9: 791-3, http://dx.doi.org/10.1056/ NEJMp 1214750

Jones, Alison (2015) 'Open Access Matters to More than Academics, and Here's Why', Book Machine, http://bookmachine.org/2015/07/15/ open-access/ (accessed 26 August 2015)

Kronick, D.A. (1990) 'Peer Review in 18th-Century Scientific Journalism', FAMA: Fournal of the American Medical Association 263.10: 1321, http:// jama.jamanetwork.com/article.aspx?articleid=380935

Larivière, V.; Haustein, S. and Mongeon, P. (2015) 'The Oligopoly of Academic Publishers in the Digital Era', PLOS ONE 10.6, p.e0127502, http://journals.plos.org/plosone/article?id=10.1371/ journal.pone.0127502

Liesegang, T.J. (2013) 'The Continued Movement for Open Access to Peer-Reviewed Literature', American Fournal of Ophthalmology 156.3: 423-32, www.sciencedirect.com/science/article/pii/ S0002939413003097

Markram, H. and Markram, K. (2011) 'Frontiers Research: Seek, Share and Create', in M. Cockell, J. Billotte, F. Darbellay and F. Waldvogel (eds), Common Knowledge: The Challenge of Transdisciplinarity, Lausanne: Presses Polytechniques et Universitaires Romandes (EFPL): 145-62

Moed, H.F. (2007) 'The Effect of "Open Access" on Citation Impact: An Analysis of ArXiv's Condensed Matter Section', Fournal of the American Society for Information Science and Technology 58.13: 2047-54, http://onlinelibrary.wiley.com/doi/10.1002/asi.20663/

Nosek, B.A. et al. (2015) 'Promoting an Open Research Culture', Science 348.6242: 1422-5, http://science.sciencemag.org/content/348/6242/1422

Outsell (2015) Open Access 2015: Market Size, Share, Forecast, and Trends, Burlingame CA and London: Outsell

Salem, D.N. and Boumil, M.M. (2013) 'Conflict of Interest in OpenAccess Publishing’, New England Fournal of Medicine 369.5: 491, http://dx.doi.org/10.1056/NEJMc1307577

Swan, A. (2012) Policy Guidelines for the Development and Promotion of Open Access, Paris: United Nations Educational, Scientific and Cultural Organization (UNESCO), http://unesdoc.unesco.org/ images/0021/002158/215863e.pdf (accessed 8 February 2016)

Tadros, M. (2011) 'The Pulse of Egypt's Revolt', IDS Bulletin 43.1, http://bulletin.ids.ac.uk/idsbo/issue/view/33

Wiley, D. (2006) 'Open Source, Openness, and Higher Education', Innovate: Fournal of Online Education 3.1: 1

Wiley, D. and Green, C. (2012) 'Why Openness in Education?', Game Changers: Education and Information Technologies: 201-14, https://net.educause.edu/ir/library/pdf/pub72036.pdf

Wiley, D. and Hilton, J. (2009) 'Openness, Dynamic Specialization, and the Disaggregated Future of Higher Education', International Review of Research in Open and Distance Learning 10.5: 1-8

Wolpert, A.J. (2013) 'For the Sake of Inquiry and Knowledge - The Inevitability of Open Access', New England Journal of Medicine 368.9: 785-7, http://dx.doi.org/10.1056/NEJMp1211410 


\section{Glossary}

AAWORD Association of African Women for Research and Development

ADB Asian Development Bank

AfDB African Development Bank

APC Article Processing Charge

ASDP Agricultural Sector Development Programme

ATRCW African Training and Research Centre for Women

AWID Association for Women's Rights in Development

BCR benefit-cost ratio

BMZ Federal Ministry for Economic Cooperation and Development

BRICS Brazil, Russia, India, China and South Africa

CABI Centre for Agriculture and Bioscience International

CC Creative Commons

CCA climate change adaptation

CFS Committee on World Food Security

CHSJ Centre for Health and Social Justice

CICERO Centre for International Climate and Environmental Research

CNIC National Centre of Scientific Research

CSP Centre for Social Protection

DFID Department for International Development

DGIS Dutch Ministry of Foreign Affairs

DRR disaster risk reduction

EC European Commission

ECA Economic Commission for Africa

EMERGE Engendering Men: Evidence on Routes to Gender Equality

EPTA Expanded Programme of Technical Assistance

ESA Economia Sviluppo Agricolo (Agricultural Development Economics)

FAO Food and Agriculture Organization

FISP Farm Input Subsidy Programme

GAD gender and development

GDP Gross Domestic Product

GPS Gender, Power and Sexuality

ha hectare

HD human development

HDR Human Development Report

HGSF home-grown school feeding

HIPC Highly-Indebted Poor Countries

ICT information and communications technology

IDS Institute of Development Studies

IFPRI International Food Policy Research Institute

IIED International Institute for Environment and Development

ILO International Labour Office

ILO International Labour Organization

IMF International Monetary Fund

INGO international non-governmental organisation 
IPCC Intergovernmental Panel on Climate Change

IR institutional repository

LSE London School of Economics and Political Science

MAFC Ministry of Agriculture, Food Security and Cooperatives, Tanzania

MDG Millennium Development Goal

MEGEN Men for Gender Equality Now

MEGS Maharashtra Employment Guarantee Scheme

MGNREGA Mahatma Gandhi National Rural Employment Guarantee Act

MIT Massachusetts Institute of Technology

MOOC Massive Open Online Course

NAIVS National Agricultural Input Voucher Scheme

NGO non-governmental organisation

NIEO New International Economic Order

ODA Overseas Development Administration

ODI Overseas Development Institute

OECD Organisation for Economic Co-operation and Development

OPEC Organization of the Petroleum Exporting Countries

PAMSCAD Programme of Actions to Mitigate the Social Costs of

Adjustment

PLA participatory learning and action

PSNP Productive Safety Net Programme

R\&D research and development

RHVP Regional Hunger and Vulnerability Programme

RLP Refugee Law Project

RPC Research Programme Consortium

SCR Strengthening Climate Resilience

SDG Sustainable Development Goal

SGBV sexual and gender-based violence

SID Society of International Development

Sida Swedish International Development Cooperation Agency

SOAS School of Oriental and African Studies

SOW Subordination of Women

SP social protection

SPL Sexuality, Poverty and Law

SSA sub-Saharan Africa

STEPS Social, Technological and Environmental Pathways to Sustainability STFX St. Francis Xavier University

TAMNEAC Training and Mobility Network for the Economic Analysis

of Conflict

UEA-DEV School of International Development at the University of

East Anglia

UN United Nations

UNDP United Nations Development Programme

UNEP United Nations Environment Programme

UNESCO United Nations Educational, Scientific and Cultural Organization

UNFCCC United Nations Framework Convention on Climate Change

UNICEF United Nations Children's Fund

UNIFEM United Nations Development Fund for Women

UNODC United Nations Office on Drugs and Crime 
UNTL National University of Timor-Leste

UNU-WIDER United Nations University World Institute for Development Economics Research

USSR Union of Soviet Socialist Republics

VAMP Veshya Anyay Mukti Parishad

WCED World Commission on Environment and Development

WHO World Health Organization

WID women in development 
This page is intentionally left blank 
Volume 47 (2016)

No. 1 Opening Governance

No. 1 A Connecting Perspectives on Women's Empowerment

\section{Volume 46 (2015)}

No. 1 Towards Systemic Approaches to Evaluation and Impact

No. 2 Graduating from Social Protection?

No. 3 Business, State and Society: Changing Perspectives, Roles and Approaches in Development

No. 4 Beijing+20: Where Now for Gender Equality?

No. 5 What is the Unique Contribution of Volunteering to International Development?

No. 6 Life in a Time of Food Price Volatility

\section{Volume 45 (2014)}

No. 1 Undressing Patriarchy: Men and Structural Violence

No. 2-3 New Perspectives from PhD Field Research

No. 4 China and International Development: Challenges and Opportunities

No. 5 Localising Governance

No. 6 Rethinking Impact Evaluation for Development

Volume 44 (2013)

No. 1 Piecing it Together: Post-conflict Security in an Africa of Networked, Multilevel Governance

No. 2 Real Time Monitoring for the Most Vulnerable

No. 3 Seeing the Unseen: Breaking the Logjam of Undernutrition in Pakistan

No. 4 China and Brazil in African Agriculture

No. 5-6 Whose Goals Count? Lessons for Setting the Next Development Goals

Periodical ID statement The IDS Bulletin (ISSN 0265-5012 print) is published bi-monthly in January, March, May, July, September and November. Mailing agent: Gary Edwards, Institute of Development Studies, Library Road, Brighton BN1 9RE, UK. Tel: +44 (0)1273 606261 idsbulletin@ids.ac.uk

Postmaster Send all address changes to IDS Bulletin, Gary Edwards, Institute of Development Studies, Library Road, Brighton BN1 9RE, UK. Tel: +44 (0)1273 606261 idsbulletin@ids.ac.uk

Journal customer services For ordering information, claims and any enquiry concerning your journal subscription please contact Gary Edwards, Institute of Development Studies, Library Road, Brighton BN1 9RE, UK. Tel: +44 (0)1273 606261 idsbulletin@ids.ac.uk

Print details printed in the UK by Nexus Design \& Print Ltd, 99-102 Preston Road, Brighton BN1 6AF, UK.

ISSN 0265-5012 (print), 1759-5436 (online)

Online open access This journal is available online at bulletin.ids.ac.uk. Visit the site to search for articles and authors and register for table of contents email alerts. 
Institute of

Development Studies

\section{Development Studies - Past, Present and Future}

Editors Alia Aghajanian and Jeremy Allouche

Volume 47 | Number 2 | May 2016

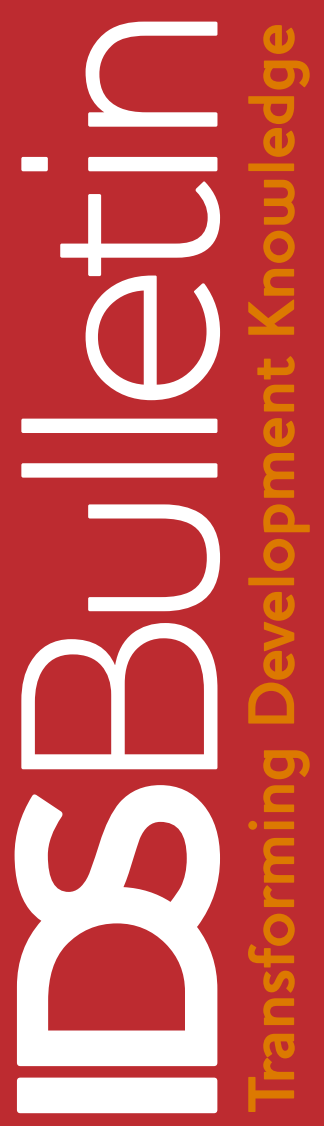

Foreword

Melissa Leach

Introduction: Development Studies - Past, Present and Future

Alia Aghajanian and Jeremy Allouche

From Development of the 'Other' to Global Governance for Universal and Sustainable Development

Richard Jolly and Ricardo Santos

Agricultural Input Subsidies in Sub-Saharan Africa Tamahi Kato and Martin Greeley

Adapting to Climate Change: Transforming Development?

Rachel Godfrey-Wood and Lars Otto Naess

Broadening Social Protection Thinking

Stephen Devereux and Ana Solórzano

The Dialectics of Urban Form and Violence

Jaideep Gupte and Hadeer Elshafie

Challenging the Asymmetries of Power: A Review of the Institute of Development Studies (IDS) Contribution

Maro Pantazidou and John Gaventa

Gender, Sexuality and Development: Revisiting and Reflecting

Zahrah Nesbitt-Ahmed and Jenny Edwards

The Evolution of Ethnicity Theory: Intersectionality, Geopolitics and

Development

Naysan Adlparvar and Mariz Tadros

Is Openness Enough?

Hani Morsi and Alison Norwood
'Development needs to be reframed from narrowly tackling poverty and vulnerability, to navigating complex challenges in ways that reduce inequalities and build more sustainable, inclusive and secure futures for people and societies.'

